UNIVERSIDADE DE SÃO PAULO

INSTITUTO DE GEOCIÊNCIAS

Inventário e avaliação de locais de interesse geológico em Iguape e llha Comprida - SP: bases para o uso turístico e educativo em áreas protegidas costeiras

\title{
STEPHANI SOMEKAWA
}

Dissertação apresentada ao Programa de Pós-Graduação em Mineralogia e Petrologia para obtenção do titulo de Mestre em Ciências

Área de concentração: Mineralogia Experimental e Aplicada

Orientadora: Profa. Dra. Maria da Glória Motta Garcia

SÃO PAULO 


\section{UNIVERSIDADE DE SÃO PAULO \\ INSTITUTO DE GEOCIÊNCIAS}

Inventário e avaliação de locais de interesse geológico em Iguape e Ilha Comprida-SP: bases para o uso turístico e educativo em áreas protegidas costeiras

\section{STEPHANI SOMEKAWA}

Orientadora: Profa. Dra. Maria da Glória Motta Garcia

Dissertação de Mestrado

№ 819

COMISSÃO JULGADORA

Dra. Maria da Glória Motta Garcia

Dr. Antonio Liccardo

Dr. Paulo César Boggiani

SÃO PAULO 
Autorizo a reprodução e divulgação total ou parcial deste trabalho, por qualquer meio convencional ou eletrônico, para fins de estudo e pesquisa, desde que citada a fonte.

Serviço de Biblioteca e Documentação do IGc/USP

Ficha catalográfica gerada automaticamente com dados fornecidos pelo(a) autor(a) via programa desenvolvido pela Seção Técnica de Informática do ICMC/USP

Bibliotecários responsáveis pela estrutura de catalogação da publicação: Sonia Regina Yole Guerra - CRB-8/4208 | Anderson de Santana - CRB-8/6658

Somekawa, Stephani

Inventário e avaliaçăo de locais de interesse geológico em Iguape e Ilha Comprida ? SP: bases para - uso turístico e educativo em áreas protegidas costeiras / Stephani Somekawa; orientadora Maria da Glória Motta Garcia. -- Så Paulo, 2019.

$120 \mathrm{p}$.

Dissertaçå (Mestrado - Programa de Pós-Graduaçåo em Mineralogia e Petrologia) -- Instituto de Geociências, Universidade de såo Paulo, 2019.

1. Avaliaçåo Quantitativa. 2. Geoconservaçåo. 3. Geossítios. 4. Inventário. 5. Litoral sul do estado de så Paulo. I. Motta Garcia, Maria da Glória, orient. II. Título. 
Dedico esse trabalho as futuras gerações, que os locais aqui apresentados proporcionem a elas, experiências tão ricas quanto as que eu vivi. 


\section{AGRADECIMENTOS}

O processo de elaboração desse trabalho passou por diversos períodos de mudanças e reflexões pessoais em que pude contar com a colaboração de muitas pessoas que, direta ou indiretamente, contribuíram para que ele chegasse a sua conclusão. Não serei capaz de expressar em poucas linhas a imensa gratidão que tenho por todos, mas deixo aqui um simples agradecimento repleto de carinho e sinceridade.

À minha orientadora Prof. ${ }^{a}$ Dra. Maria da Glória por ter me orientado do início aos últimos minutos do segundo tempo, à ela agradeço por todo aprendizado, paciência, generosidade, atenção e profissionalismo, uma pessoa que admiro muito como profissional e como mulher.

À toda minha família, pelo apoio sempre que precisei, vocês são maravilhosos.

Aos professores do IGC, Paulo C. Bogianni, Denise Bacci, Lucilene Martins, Cristine Bourotte, Eliane Del Lama, agradeço pelo apoio, pelas recomendações, disciplinas, e por terem me aceitado como supervisora de estágio no programa de formação de professores.

Aos Professores Paulo Giannini, e Carlos Guedes pelas recomendações e referências que foram de grande ajuda para esse trabalho.

Aos funcionários do IGC por toda ajuda e colaboração.

À Raquel Romão, por ter sido a primeira pessoa a me incentivar a fazer mestrado, obrigada pela de amizade, viagens e experiências vividas nesses anos.

Ao camarada, ou melhor Lucas Agustini pela amizade, incentivo, aprendizado, conselhos, broncas, e pelo manual de sobrevivência cruspiana, obrigada por ter me mostrado o caminho para colocar a mão na massa, quando eu não tinha mais ferramentas.

As amizades que se consolidaram durante o período do mestrado, Thomas Akabane (Kano), Julio Lopes, Fernando Araujo (Froxo), Nicholas Lima, Jonathan Barré, foram tantas contribuições, tantos momentos, discussões, fogueiras, cafezinhos, que essa amizade vá além dos muros da academia e das fronteiras da vida.

Aos membros do Núcleo GeoHereditas Vanessa Mucivuna, Fernanda Reverte, , Débora Queiroz, Fabiola Menezes e Karlla Arruda pelas contribuições, conversas, risadas e desabafos ao longo de todo o mestrado e ao Carlos Mazoca por ajudar a me localizar e orientar quando eu estava perdida no mundo dos mapas. 
Aos amigos que me acompanham desde a graduação Lorena Galati, Samantha (Pão), Patrícia Tavares, Suellyn Garcia, Daniel (Caverna), Yuri Polvilho, Pedro Cunha, Afonso (Mafa), Marina, obrigada pelas conversas, conselhos, risadas, forrós e viagens.

Agradeço as amizades que me ajudaram a sobreviver na bolha cruspiana, Celma, Lika, Dri, Baca, Poca. Ao Kaique por toda força e parceria que tem me dado, pelos chocolates, e por ter transformado o 406 num lar mais habitável. À Carol axnega, por me ouvir, pelas reflexões da vida, por realmente se preocupar em ajudar e por ter me alimentado nos momentos finais da dissertação.

À Ingrid, pela longa amizade, por se preocupar, me dar apoio e estar presente mesmo estando longe, desde sempre, para sempre.

A Flávia e a Sara pela oportunidade que me deram em poder trabalhar na Tangará, foi uma fase muito rica e inspiradora, essa experiência foi fundamental para estabelecer alguns rumos na minha vida.

Agradeço aos amigos do Núcleo de Artes Afro-brasileiras da USP, em especial ao Mestre Pinguim pelo valioso aprendizado que venho recebendo nesses últimos anos, através da capoeira pude mudar minha percepção sobre a vida e o olhar sobre o mundo.

Agradeço a CAPES por fomentar subsídios para a realização desse trabalho por meio da concessão de bolsa de mestrado no período de seis meses.

A todos vocês escrevo aqui, com lágrimas nos olhos, a minha mais profunda gratidão. 
"Um dia eu ainda vou me redimir por inteiro, do pecado do intelectualismo, se Deus quiser.

Não vou ter mais necessidade de falar nada, de ficar pensando em termos descontrarios, de tudo, pra tentar explicar às pessoas que eu não sou perfeito, mas que o mundo também não é, que eu não estou querendo ser o dono da verdade, que eu não estou querendo fazer sozinho uma obra que é de todos nós e de mais alguém, que é o tempo, o verdadeiro grande alquimista, aquele que realmente transforma tudo. Um pequenino grão de areia é o que eu sou. Só que o grão de areia já conseguiu, sendo tão grande ou maior do que eu, ser pequenininho e não precisar se mostrar mais, ficar lá, trabalha em silêncio, mar mineiro, eu sou mais baiano ainda." 


\section{RESUMO}

Somekawa, S., 2019, Inventário e avaliação de locais de interesse geológico em Iguape e llha Comprida - SP: bases para o uso turístico e educativo em áreas protegidas costeiras [Dissertação de Mestrado], São Paulo, Instituto de Geociências, Universidade de São Paulo, 120 p.

Os municípios de Iguape e llha Comprida, litoral sul do estado de São Paulo, estão inseridos no sistema estuarino-lagunar Cananeia e Iguape, região costeira de importante valor em termos de conservação da natureza. Várias unidades de conservação geridas em nível municipal, estadual e nacional formam um mosaico que tem como objetivo proteger áreas chave para a manutenção do meio natural. Com o objetivo de promover a conservação e o uso dos locais de interesse geológico da região, procedeu-se o inventário, que selecionou 12 geossítios e um sítio da geodiversidade, distribuídos em seis Categorias Geológicas (CG): 1) CG Geomorfologia e evolução da paisagem: Morro do Espia e Maciço da Jureia; 2) CG Evolução quaternária: Cordões litorâneos e Paleodunas da praia da Jureia, Terraços holocênicos do Pontal da Trincheira, Dunas, paleodunas e paleolagunas da llha Comprida e Campo de dunas ativas do Araçá; Processos sedimentares da desembocadura do rio Ribeira de Iguape; 3) CG Magmatismo alcalino do Cretáceo Tardio: Intrusão alcalina da Ilha Comprida; 4) CG Zonas de cisalhamento: Granito Iguape com feições miloníticas; 5) CG Magmatismo granítico sin-tectônico: Granito Iguape no Morro do Espia; 6) CG Terreno Curitiba: Granulitos do Complexo Itatins na Cachoeira do Paraíso e Paragnaisses da Praia da Jureia, o único sítio da geodiversidade. Os sítios registram a história geológica da área, que vai desde o Paleoproterozoico, incluindo terrenos que mais tarde foram afetados pelo Ciclo Brasiliano, até o Cenozoico, marcado por registros de regressão e progradação do nível relativo do mar. Por meio da avaliação quantitativa avaliou-se a relevância cientifica,o potencial de uso educativo e turístico e o risco de degradação. Todos os locais de interesse geológico inventariados estão localizados em áreas protegidas, que estão em constante crescimento populacional e que sofrem com a grande pressão imobiliária. A fim de contribuir para a valorização e divulgação destes locais foram elaboradas propostas de uso turístico e educativo, visando propiciar, além do diálogo entre universidade e população, um sentimento de pertencimento e coresponsabilização sobre o meio ambiente.

Palavras chave: Avaliação Quantitativa, Geoconservação, Geossítios, Inventário, litoral sul do estado de São Paulo. 


\begin{abstract}
The municipalities of Iguape and Ilha Comprida, Southern coast of the state of São Paulo, Brazil, are included in the Cananeia and Iguape Estuarine-lagoon system, an important coastal region in terms of nature conservation. Several protected areas exist in the area and are managed at the municipal, state and national levels, forming a mosaic that aims to protect key areas for the maintenance of the natural environment. In order to promote the conservation and use of the geological sites of the region, the inventory was carried out, selecting 12 geosites and one geodiversity site, distributed in six Geological Categories (CG): 1) CG Geomorphology and evolution of landscape: Morro do Espia and Jureia Massif; 2) CG Quaternary evolution: Coastal strings and Paleodunas of Jureia beach, Holocene Terraces of Pontal da Trincheira, Dunes, paleodunes and paleolagoons of llha Comprida and Field of active dunes of Araçá; Sedimentary processes of the mouth of the Ribeira de Iguape river; 3) GC Late Cretaceous alkaline magmatism: Alkaline intrusion of llha Comprida; 4) CG Shear zones: Iguape granite with mylonitic features; 5) GC Syntectonic granite magmatism: Iguape Granite in Morro do Espia; 6) CG Curitiba Terrane: Granulites of the Itatins Complex in the Paraíso Waterfall and Paragnaisses of Jureia Beach, the only geodiversity site. The sites record the geological history of the area, ranging from the Paleoproterozoic, including terranes that were later affected by the Brasilian Cycle, to the Cenozoic, marked by records of both regression and progression of the relative sea level. The quantitative evaluation used criteria such as scientific relevance, potential of educational and tourist use and risk of degradation. All geological sites of the inventory are located in protected areas, which are constantly growing in population and suffering from a great real estate pressure. In order to contribute to the valorisation and dissemination of these sites, proposals for tourism and educational use were developed, aiming to provide, in addition to the dialogue between universities and the population, a sense of belonging and co-responsibility on the environment.
\end{abstract}

Key words: Geoconservation, Geosites, Inventory, Quantitative Assessment, Southern coast of the state of São Paulo. 


\section{LISTA DE FIGURAS}

Figura 1 - Mapa de localização e acesso dos municípios de Iguape e llha Comprida, litoral sul do estado de São Paulo.

Figura 2 - Mapa tectônico dos terrenos Apiaí, Guaxupé, Curitiba, Embu e Luís Alves. O polígono pontilhado vermelho corresponde à área de estudo (adaptado de HEILBRON et al., 2004).

Figura 3 - Mapa geológico da região, com destaque para as formações do período quaternário. ZCL- Zona de Cisalhamento Lancinha; ZCC- Zona de Cisalhamento Cubatão; ZCI Zona de Cisalhamento Itariri. (Guedes, 2009).

Figura 4 - Mapa de localização dos geossítios e sítios da geodiversidade. 1) Maciço da Jureia; 2) Morro do Espia; 3) Processos sedimentares da desembocadura do rio Ribeira de Iguape; 4) Campo de dunas ativas do Araçá; 5) Dunas, paleodunas e paleolagunas da llha Comprida a - Paleoduna em área urbanizada, b e c paleolagunas, $d$ - paleodunas com expressiva erosão, e- paleodunas densamente vegetadas; 6) Terraços holocênicos do Pontal da Trincheira; 7) Cordões litorâneos e paleodunas da praia da Jureia a - Paleodunas, b- dunas frontais e nebkas; 8) Intrusão alcalina da Iha Comprida; 9) Granito Iguape com feições miloníticas; 10) Granito Iguape no Morro do Espia; 11) Granulitos do Complexo Itatins na Cachoeira do Paraíso; 12) Paragnaisses da Praia da Jureia; 13) Paragnaisses da Cachoeira Grande.

Figura 5 - Geossítio "Granulitos do Complexo Itatins na Cachoeira do Paraíso". A) Poço principal da cachoeira com destaque para xenólito de rocha máfica; B) Boudins de rocha máfica indicativos da tectônica extensional; C) Xenólito de rocha máfica deformado. Plano axial paralelo à foliação principal; D) Dobra intrafolial com plano axial paralelo à foliação da rocha; E) Foliação plano-axial intensamente dobrada em evento posterior; F) Recepção com informações sobre segurança e sobre a unidade de conservação; G) Infraestrutura do local com placas, mapa das trilhas, corrimões e escadas.

Figura 6 - Geossítio "Paragnaisses da Praia da Jureia". A) Aspecto bandado da rocha, com intercalações de níveis félsicos e máfics. Destaque para as lentes quartzosas sigmoidais; B) Boudins centimétricos de rochas máficas intercaladas no bandamento;C) Vista geral do afloramento, onde observa-se carros e motos próximos ao geossítio

Figura 7 - Geossítio "Granito Iguape no Morro do Espia". A) Vista do primeiro afloramento, com destaque para o dique pegmatítico; B) Detalhe do dique com turmalinas orientadas e boudinadas; C) Vista do segundo afloramento, onde observam-se xenólitos de rocha máfica; D) Ruínas de antigas construções feitas por escravos, utilizando argila, conchas e óleo de baleia.

Figura 8 - Geossítio "Granito Iguape com feições miloníticas. A) Detalhe do Granito moderadamente alterado; B) Entulho e lixo jogados entre a rocha; C) Vista geral do geossítio. 
Figura 9 - Sequência de formação do geossítio Intrusão alcalina da llha Comprida. 1 e 2 - Intrusão do magma alcalino nas rochas encaixantes do Grupo Açungui; 3 desenvolvimento da superfície do Japi no Senoniano com extensão NE-SW e intrusão de diques NW-SE; 4 - avanço da erosão na Superfície do Japi no Paleozóico/Eoceno NW-SE e intrusão de diques NE/SW; 5 - recuo erosivo da Serra do Mar e formação da Planície Costeira Cananéia-Iguape (Spinelli, 20017). 42

Figura 10- Geossítio "Intrusão alcalina da llha Comprida". A) Detalhe do sieno granito que compõe os blocos; B) Vista geral do afloramento coberto por densa vegetação. 43

Figura 11 - Geossítio "Cordões Litorâneos e Paleodunas da praia da Jureia". A) Paleodunas na linha da costa em processo de erosão; B) Paleodunas mais interiores cobertas por densa vegetação; C) Residências na beira da praia fazem contenção contra as fortes marés; D) Pequeno campo de nebkas; ao fundo o observa-se o maciço da Jureia.

Figura 12 - Geossítio "Terraços holocênicos do Pontal da Trincheira". A) Vista do afloramento, formado por areias finas holocênicas com estratificação plano-paralela, no topo, e estratificação plano-paralela com icnofóssies, na base; B) Vestígios do icnofóssil Callichirus Major; C) Turistas sobre o afloramento; D) Vandalismo observado em algumas porções do afloramento; E) Árvores derrubadas devido a intensas ressacas que resultam em alta erosão dos terraços.

Figura 13 - Geossítio "Dunas, paleodunas e paleolagunas da Ilha Comprida". A) Cordões de paleodunas intensamente vegetadas; B) Paleodunas mais próximas da linha da costa, onde é possível observar a retirada da vegetação; C) Rupturas de deflação (blowout) causadas pela reativação das paleodunas; D) Turismo na ilha onde é permitido o acesso por veículos; E) Turistas escorregando sobre as dunas, atividade que ajuda na retirada da vegetação. E) Paleolagunas na porção Sul da llha F) Paleolagunas na região norte da ilha. E e F modificado Guedes (2009). 50

Figura 14 - Geossítio "Campo de dunas ativas do Araçá". A) Vista geral do campo de dunas ativas do Araçá. Ao fundo observam-se diversas residências; B) Veículos em trânsito pelo campo de dunas, sem limitação de acesso; C) Dunas parabólicas e barcanas, que constituem o campo de dunas. 52

Figura 15 - Geossítio Processos sedimentares da desembocadura do rio Ribeira de Iguape". A) À esquerda do Valo Grande, observa-se ilha fluvial em meio ao canal, ao lado do centro histórico; B) Ponte que interliga os municípios de Iguape e llha Comprida; C) Localização dos processos causados pela abertura do Valo. 1formação de delta 2- formação de ilhas causadas pelo excesso de sedimentos, 3erosão no campo de dunas, 4 - linhas de crescimento longitudinais da ilha, pós Valo Grande. 5 - Local onde se encontrava a praia do leste.......................................... 55

Figura 16 - Geossítio "Maciço da Jureia" A) Vista do maciço a partir da praia da Jureia; B) Vista da praia da Jureia por um mirante no Maciço. 57 
Figura 17 - Geossítio "Morro do Espia. A) Vista da llha Comprida para o Morro do Espia; B) Vista do mirante do Cristo para a cidade de Iguape, localizado no Morro do Espia. É possível observar, do mirante, a planície costeira e as serranias ao fundo. A esquerda da foto encontra-se o Valo Grande. Foto B: Thomas Akabane...59

Figura 18 - - Sítio da Geodiversidade "Paragnaisses da Cachoeira Grande". A) Vista da cachoeira Grande, com detalhe para o dique de rocha máfica; B) Dobra intrafolial no paragnaisse; C) Boudins de rocha máfica.

Figura 19 - Relação do valor científico e risco de degradação dos geossítios e sítio da geodiversidade. Os locais estão numerados de 1 a 13 conforme tabelas 10 e 11 .

Figura 20 - Relação dos valores de uso potencial educativo e turístico e risco de degradação dos locais de interesse geológico dos municípios de lguape e llha Comprida. Os locais estão numerados de 1 a 13 conforme tabela 10 e 11 ..............72

Figura 21 - Mapa do enquadramento legal dos municípios de lguape e llha Comprida. Adaptado do plano de manejo da APACIP. .77

Figura 22 - Mapa de pontos do roteiro como se formou a llha Comprida?; 1) Intrusão alcalina da Ilha Comprida; 2) Terraços holocênicos do Pontal da Trincheira; 3) Paleodunas; 4) Dunas e Paleodunas do Juruvauna Paleolaguna; 5) Paleolagunas; 6) Paleodunas em área urbanizada; 7) Paleolagunas afetadas pelo Valo Grande; 8) Campo de Dunas ativas do Áraça; 9) Illhas formadas pelos Processos sedimentares do rio Ribeira de Iguape.10) Local de observação do geossítio Processos sedimentares da desembocadura do rio Ribeira de lguape.Erro! Indicador não definido.

Figura 23 - Fase 1 de evolução da llha Comprida; A) Intrusão Alcalina em Cananeia e Ilha Comprida. B) Terraços sofrendo com ações antrópicas; C) Derrubada de árvores caracterizando intensa erosão nesse trecho; D) Presença de icnofósseis Callichirus Major, evidência de mudança no nível do mar. Adaptado de Guedes (2009).

Figura 24 - Fase 2 de evolução da llha Comprida; A e B) Paleodunas densamente vegetadas, localizam-se mais ao interior cerca de 500 metros da linha de costa atual; C) Paleodunas com rupturas de deflação, ocasionadas pela retirada da vegetação, essas se encontram na linha de costa. Adaptado de Guedes (2009).....87

Figura 25 - Fase 4 de evolução da llha Comprida: A e B) Paleolagunas, formadas na fase 1; C e D) Paleodunas em área intensamente urbanizada. Adaptado de Guedes (2009).

Figura 26 - Fase 5 de evolução da llha Comprida: A e B) Campo de dunas ativas do Araçá, evidencia de extremidade da ilha antes da abertura do Valo Grande; C) Processos sedimentares da desembocadura do rio Ribeira de Iguape, Pontos assinalados correspondem a ilha e crescimento da ilha decorrentes do alto fluxo de sedimentos. Adaptado Guedes (2009). 
Figura 27 - Mapa de localização e de pontos do roteiro cicloturístico do Lagamar Paulista. 91

\section{LISTA DE TABELAS}

Tabela 1 - Parâmetros utilizados para avaliação quantitativa do valor científico de locais de interesse geológico de acordo com Rocha et al. (2016).......................... 22

Tabela 2 - Parâmetros utilizados para avaliação quantitativa do uso educativo e turístico de locais de interesse geológico de acordo com Rocha et al. (2016). 23

Tabela 3 - Parâmetros utilizados para avaliação quantitativa do risco de degradação de locais de interesse geológico de acordo com Rocha et al. (2016)..................... 25

Tabela 4 - Pesos atribuídos para avaliação quantitativa do valor científico de acordo

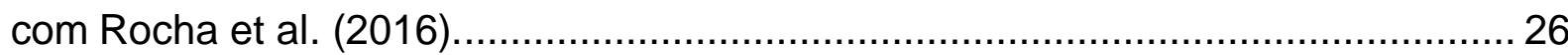

Tabela 5 - Pesos atribuídos para avaliação quantitativa do risco de degradação de acordo com Rocha et al. (2016)........................................................................ 27

Tabela 6 - Valores para classificação do risco de degradação dos locais de interesse geológico de acordo com Rocha et al. (2016). ................................................. 27

Tabela 7 - Pesos atribuídos para avaliação quantitativa do potencial de uso educativo e turístico de acordo com Rocha et al. (2016).................................... 27

Tabela 8 - Geossítios e sítios da geodiversidade dos municípios de Iguape e llha Comprida distribuídos segundo as categorias geológicas definidas em Garcia et al. (no prelo). Interesse geológico principal de acordo com Rocha et al. (2016) GEOSSIT. 'Sítio da geodiversidade.

Tabela 9 - Resultados da avaliação quantitativa de valor científico dos locais de interesse geológico de lguape e llha Comprida de acordo com a plataforma GEOSSIT. * Sítio da geodiversidade.

Tabela 10 - Resultados da avaliação quantitativa do risco de degradação dos locais de interesse geológico de Iguape e llha Comprida de acordo com a plataforma GEOSSIT. "Sítio da geodiversidade. 64

Tabela 11 - Resultados da avaliação quantitativa do uso potencial educativo e turístico dos locais de interesse geológico de Iguape e llha Comprida de acordo com a plataforma GEOSSIT. "Sítio da geodiversidade.

Tabela 12 - Prioridade de proteção científica e prazo de proteção dos locais de interesse geológico dos municípios de lguape e llha Comprida. "Sítio da geodiversidade. 69

Tabela 13 - Relação de UCs nos municípios de Iguape e llha Comprida................. 75

Tabela 14 - Enquadramento legal dos geossítios e sítio da geodiversidade e risco de degradação. *Sítio da geodiversidade 
Tabela 15 - Associação das fases de formação da ilha com os geossítios e suas

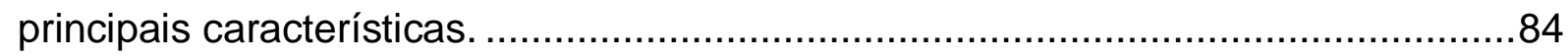

Tabela 16 - Locais de interesse geológico incluídos no Roteiro Cicloturistico do

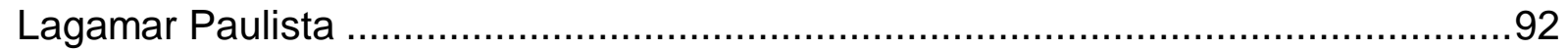





\section{SUMÁRIO}

1 INTRODUÇÃO

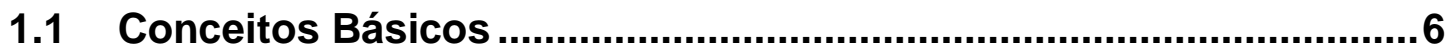

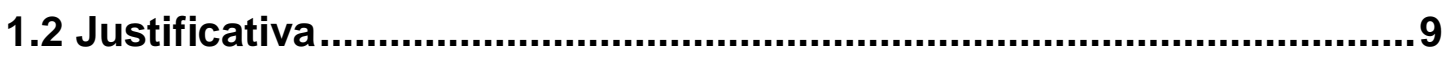

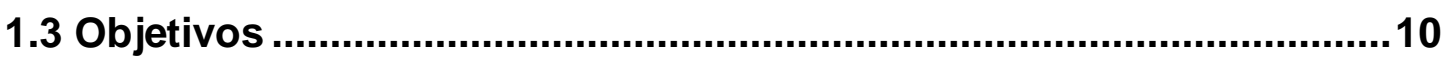

2 CARACTERIZAÇÃO DE IGUAPE E ILHA COMPRIDA

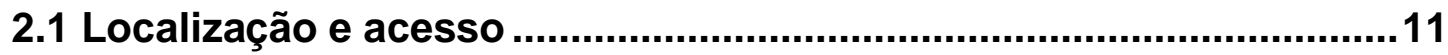

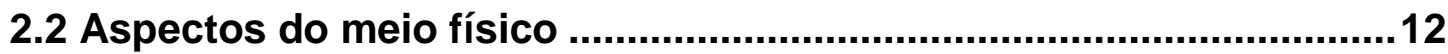

2.2.1 Contexto Geomorfológico ...................................................12

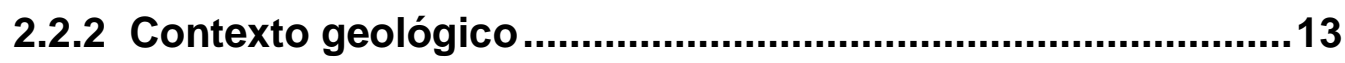

2.3 Aspectos socioeconômicos e culturais ..........................................16

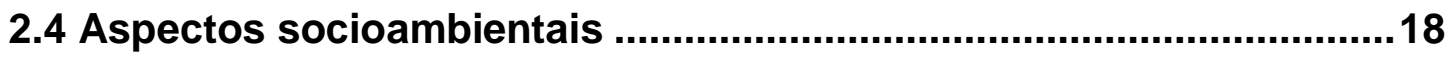

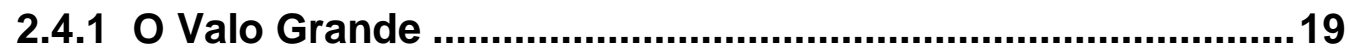

3 METODOLOGIA

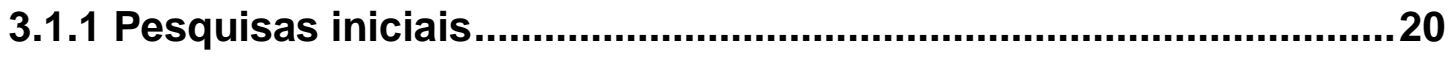

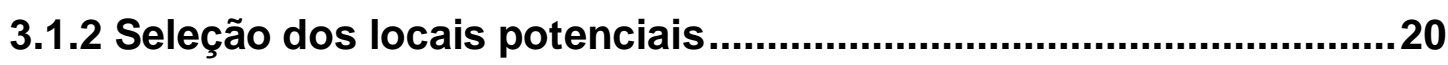

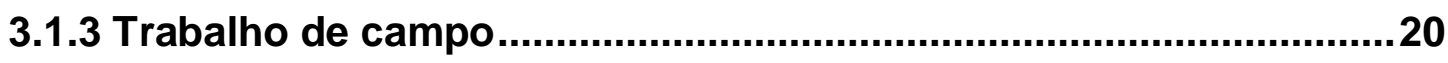

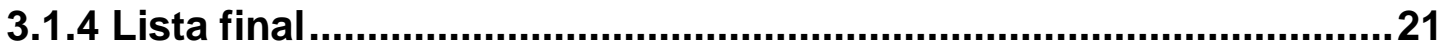

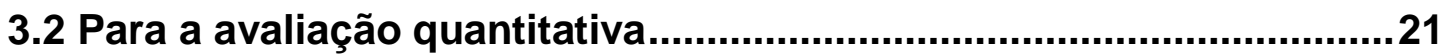

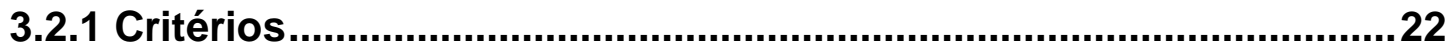

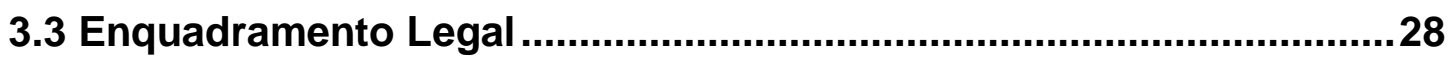

4 DESCRIÇÃO DOS LUGARES DE INTERESSE GEOLÓGICO ...........................29

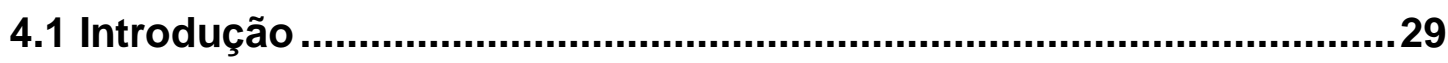

4.2 Descrição dos locais de interesse geológico .......................................32

4.2.1 CG - Terreno Curitiba ............................................................32

Geossítio "Granulitos do Complexo Itatins na Cachoeira do Paraíso" .32

Geossitio "Paragnaisses da Praia da Jureia" ........................................35

4.2.2 CG - Magmatismo granítico sin-tectônico..............................37

Geossítio "Granito Iguape no Morro do Espia"...................................37

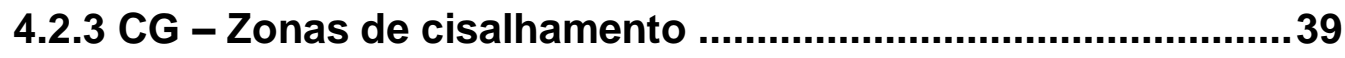

Geossítio "Granito Iguape com feições miloníticas"..............................39

4.2.4 CG - Magmatismo alcalino do Cretáceo Tardio ......................41

Geossítio “Intrusão alcalina de Ilha Comprida".....................................41 


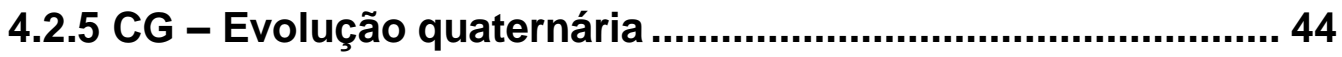

Geossítio "Cordões Litorâneos e Paleodunas da praia da Jureia"....... 44

Geossítio "Terraços holocênicos do Pontal da Trincheira" .................. 46

Geossítio "Dunas, paleodunas e paleolagunas da Ilha Comprida"...... 48

Geossítio "Campo de dunas ativas do Araçá" .................................... 51

Geossítio "Processos sedimentares da desembocadura do Rio Ribeira de

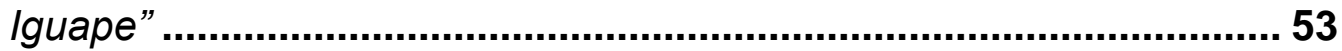

4.2.6 CG - Geomorfologia e evolução da paisagem...................... 56

Geossítio "Maciço da Jureia"........................................................ 56

Geossítio "Morro do Espia"........................................................... 58

Sítio da Geodiversidade "Paragnaisses da Cachoeira Grande" .......... 60

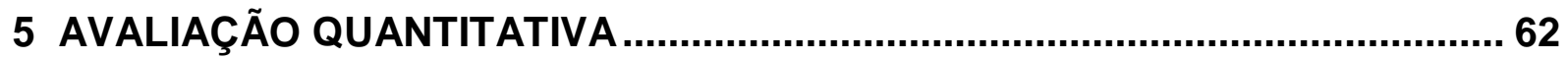

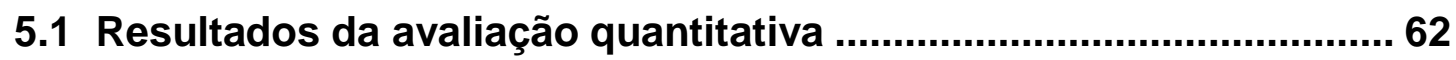

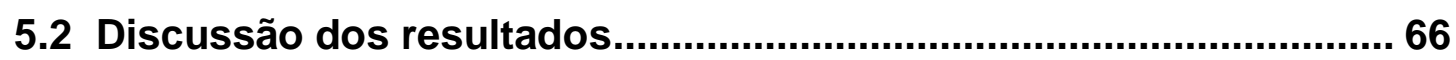

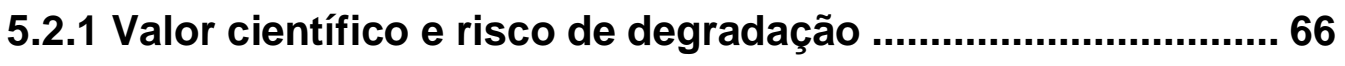

5.2.2 Potencial uso turístico e educativo....................................... 70

6 - PROPOSTAS DE USO E GESTÃO DOS LOCAIS DE INTERESSE

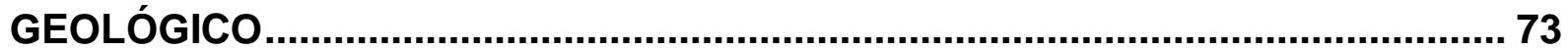

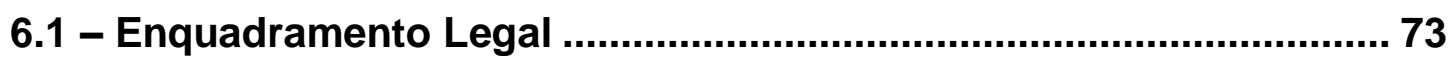

6.2 Integração dos dados e propostas de valorização e divulgação..... 78

6.2.1 Propostas para a APA Cananeia Iguape e Peruíbe (APACIP)78

6.2.2 Propostas para a Estação Ecológica Jureia-Itatins (EEJI) ... 79

6.2.3 Propostas para a APA Ilha Comprida (APAIC) ..................... 81

6.3 Propostas de roteiros geoturísticos................................................ 82

6.3.1 Roteiro 1 - Como se formou a llha Comprida? .................... 83

6.3.3 Proposta 2 - Roteiro cicloturístico do Lagamar Paulista..... 91

7 CONSIDERAÇÕES FINAIS E CONCLUSÕES ............................................... 93

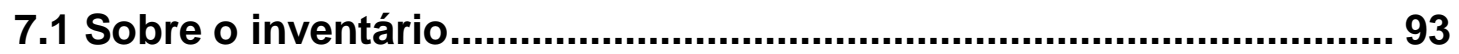

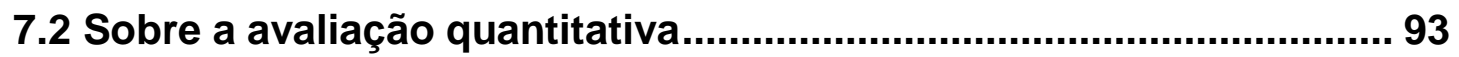

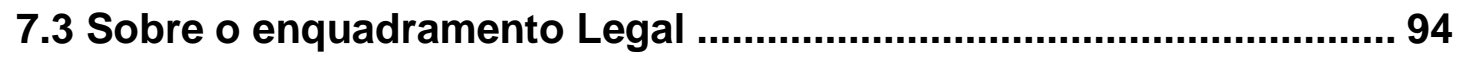

7.4 Sobre a integração dos dados e propostas de roteiros geoturísticos95

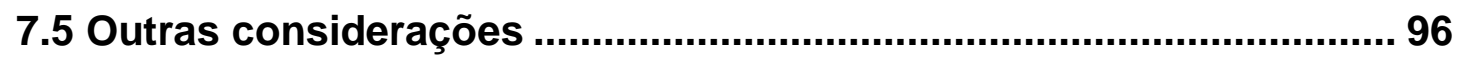

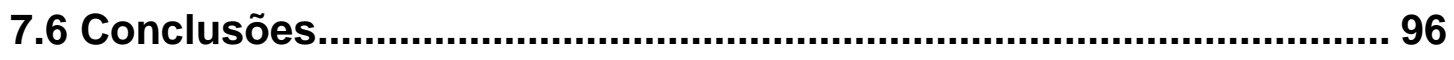

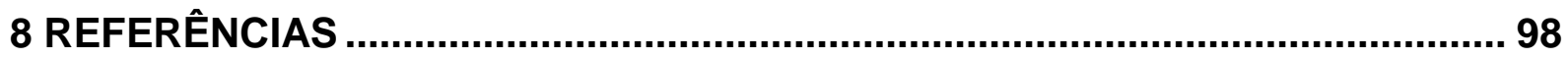




\section{INTRODUÇÃO}

Uma das questões atuais mais discutidas sobre conservação da natureza envolve o uso desenfreado de recursos naturais, utilizados principalmente para o desenvolvimento tecnológico e industrial. Essa evolução tecnológica surge para suprir as necessidades de uma sociedade moderna que cresce demasiadamente com a visão de que os recursos naturais são infinitos, caracterizando-se, segundo Bacci e Kuntschik (2013), em um modelo utilitarista que representa uma prática predatória de apropriação da natureza. Os mesmos autores afirmam que, no Brasil, esse modelo de exploração foi implantado desde o início da colonização devido à grande disponibilidade de água e de riquezas minerais, modelo que permeou por muito tempo.

Essas explorações tiveram início principalmente nas zonas costeiras do país, que possuem grande diversidade de recursos naturais. Além disso, os ecossistemas costeiros abrigam recursos de alta relevância ambiental e que proporcionam um sem-número de serviços essenciais para a vida humana (MMA, 2010). As zonas costeiras começaram a desempenhar um importante papel econômico e, consequentemente, tiveram um expressivo crescimento populacional sem o devido planejamento.

As regiões costeiras são complexas e muito frágeis, suscetíveis a mudanças, pois vários fatores tais como atmosféricos, terrestres e marinhos, influenciam no equilíbrio ambiental dessas áreas (Souza, 2010). O uso e a ocupação antrópica sem planejamento causam sérias consequências para 0 meio ambiente $e$, consequentemente, para a população.

Outra questão atual importante são os impactos decorrentes das mudanças climáticas, que vêm ganhando grande importância nos debates sobre conservação da natureza, devido a eventos extremos que afetam principalmente as regiões costeiras, tais como aumento do nível do mar, erosão, enchentes, secas prolongadas, mudanças na temperatura, precipitação e nebulosidade, entre outros (Souza, 2010). Os ecossistemas das zonas costeiras podem sofrer danos muitas vezes irreversíveis, pois são regiões vulneráveis a mudanças climáticas por conta de sua fragilidade e limitada capacidade de adaptação (MMA, 2010). 
A ocorrência cada vez mais frequente destes eventos implica em urgência nas ações para resolução destes problemas, pois afetam não só a sociedade como também a biodiversidade e a geodiversidade (Souza, 2010).

Como consequência destas e de outras questões, movimentos conservacionistas para a proteção da biodiversidade começaram a surgir no fim do século 19, incentivando a criação de áreas de proteção ambiental. Na década de 70, questões que envolvem "meio ambiente e desenvolvimento" vieram à tona com publicações apresentando o esgotamento dos recursos naturais e as consequências dos impactos causados pela produção capitalista. Surge, então, o conceito de desenvolvimento sustentável, com o objetivo de levantar a questão da problemática ambiental nas decisões políticas na esfera global (Jacobi, 2005).

Neste contexto, as áreas de proteção ambiental foram e vêm sendo criadas na esteira do avanço do debate sobre os impactos globais que a produção de bens e insumos exerce sobre o meio ambiente. $O$ discurso sobre sustentabilidade tem 0 objetivo de dar visibilidade ao tema na agenda política internacional e alcançar decisões favoráveis em todas as esferas políticas. O termo "desenvolvimento sustentável" aparece atualmente em vários cenários e tornou-se palavra-chave em campanhas de ativistas em prol do meio ambiente, conferências, workshops e outros (Jacobi, 2005).

No Brasil, as áreas protegidas são definidas pelo Sistema Nacional de Unidades de Conservação (SNUC - Lei 9.985/2000) e recebem o nome de Unidades de Conservação (UC), divididas em categorias que determinam seu tipo de uso. São áreas que visam a conservação e a gestão dos ecossistemas e dos recursos naturais e sua valorização e, em alguns casos, sua gestão. A criação destas áreas vem obedecendo, principalmente, critérios voltados à manutenção da biodiversidade, embora a grande maioria apresente valores importantes em termos de geodiversidade. Portanto, numa abordagem ecossistêmica, é fundamental para o sistema terrestre que também haja a valorização e conservação da geodiversidade, que é o substrato da biota e necessária para manter o equilíbrio da natureza.

Em termos internacionais, as áreas protegidas são geridas pela União Internacional para a Conservação da Natureza (IUCN), que teve sua criação em 1994. Desde 2002, a IUCN vem inserindo em suas diretrizes o conceito de geodiversidade como parte integrante da natureza em áreas protegidas, ressaltando o valor e a integridade dos processos biológicos e geológicos na conservação da 
natureza. No último acordo internacional realizado em 2016, no Havaí, tornou-se explícita a necessidade de se conservar de forma integral a geodiversidade e 0 patrimônio geológico em 14 resoluções criadas para o Programa Global da IUCN 2017-2020. Esse programa funcionará como um guia para a elaboração dos programas regionais, afetando o planejamento internacional de conservação do patrimônio geológico em escala global, regional, estadual e local (Brilha, 2016; Brilha, 2002).

Os municípios de Iguape e Ilha Comprida, focos desta pesquisa, estão inseridos no sistema estuarino-lagunar Cananeia e Iguape, região costeira de importante valor em termos de conservação da natureza. Várias unidades de conservação geridas em nível municipal, estadual e nacional formam um mosaico que tem como objetivo proteger áreas chave para a manutenção da flora e da fauna, da paisagem e de elementos da geodiversidade. Todos os locais de interesse geológico inventariados estão localizados em áreas protegidas, o que traz perspectivas importantes quanto ao seu uso e a conservação, pois são áreas que estão em constante crescimento populacional e cuja pressão imobiliária constitui um problema grave.

Neste sentido, a grande contribuição deste trabalho é trazer estes locais a conhecimento, fornecendo as bases para ampliar as alternativas de uso sustentável no contexto das UCs envolvidas.

Os termos geodiversidade, patrimônio geológico e geoconservação surgiram nos anos 90 como uma alternativa à necessidade de valorização do meio abiótico da natureza.

Com o atual panorama ambiental descrito acima, as atividades humanas estão diretamente relacionadas aos recursos naturais. Porém, quando o assunto é conservação do meio ambiente, o meio abiótico é menos valorizado em comparação ao meio biótico. Em decorrência disso, novos termos surgiram para dar maior visibilidade aos aspectos físicos do meio. Tendo em vista essa defasagem, surge assim o conceito dos 5 G's: Geodiversidade, Geoconservação, Patrimônio Geológico, Geoturismo e Geoparques. Esses termos passaram a ser usados pela comunidade geocientífica, que começou a desenvolver projetos e pesquisas em prol da proteção do meio abiótico, possibilitando, muitas vezes, tornar mais sustentável o seu uso. Os locais de interesse geológicos estão ganhando cada vez mais espaço nos movimentos e projetos de conservação da natureza, no Brasil e no exterior. 


\subsection{Conceitos Básicos}

\section{Geodiversidade}

Segundo Gray (2018), a geodiversidade trouxe e traz muitos benefícios para a sociedade e se caracteriza como a "espinha dorsal" para o patrimônio geológico e para a geoconservação. Segundo o aturo, é o pilar que sustenta esses dois conceitos. A geodiversidade é um termo de valor neutro, que descreve a variedade de fenômenos abióticos na Terra, equivalente à biodiversidade, e pode ser definida como "A variedade natural (diversidade) de materiais geológicos (rochas, minerais, fósseis), geomorfológicos (relevo, topografia, processos físicos), solos e características hidrológicas. Incluem suas associações, estruturas, sistemas e contribuições para paisagens" (Gray, 2013 p. 12).

Junto a esse conceito surgem outros que buscam abranger outras demandas para a conservação da diversidade geológica.

\section{Geoconservação}

Devido à exploração demasiada dos recursos naturais, foram estipuladas estratégias buscando um equilíbrio sustentável com a geodiversidade. A partir disso surgiu o conceito de "geoconservação" (Brilha, 2005). Porém se torna inviável a conservação de toda a geodiversidade da qual a humanidade depende, então foram delineadas vias de gestão sustentável da geodiversidade, que estabelecem e classificam os locais que possuem algum tipo de valor superlativo em relação aos demais. Esses valores são intrínseco, cultural, estético, econômico, funcional, científico e educativo (Gray, 2013).

Segundo Brilha (2018) a geoconservação tem como uma de suas principais atividades a seleção de sítios para a proteção legislativa ou para criar uma rede não designada de sítios importantes. Isso fez com que muitos países e organizações baseassem a sua seleção principalmente pela representatividade da geodiversidade da área.

\section{Patrimônio Geológico}

Enquanto a geodiversidade possui valor neutro, o patrimônio geológico é um termo carregado de valores que são utilizados para identificar os elementos específicos da geodiversidade, selecionados para ações de geoconservação. 
(Brilha, 2018a)

Segundo a metodologia utilizada neste trabalho, dependendo do tipo de valor que possuem, os elementos da geodiversidade recebem denominações distintas, geossítios ou sítios da geodiversidade (Brilha, 2016). Segundo o autor, geossítios são locais de relevância cientifica que podem ou não ter outros valores associados; somente esses locais serão classificados como patrimônio geológico. Sítios da geodiversidade são locais que associam-se principalmente ao potencial uso educativo e turístico.

Esses sítios são locais-chave na compreensão da história geológica de um país, região, continente e de processos geológicos de caráter global (Brilha, 2005). Para que se mantenha a integridade dos elementos da geodiversidade, além de minimizar e impedir essas ameaças, é necessária a implementação de estratégias de geoconservação. Essas estratégias são a implementação de uma metodologia de trabalho para sistematizar as tarefas de conservação e gestão dos locais de interesse geológico. Assim sendo, são necessárias as seguintes etapas, respectivamente: inventário, quantificação, enquadramento legal, valorização e divulgação e monitoramento (Brilha, 2005).

\section{Geoturismo}

Trata-se de um segmento do turismo voltado à identificação, à conservação e à divulgação do patrimônio natural não-biótico, utilizando como principais elementos a geologia e a geomorfologia (Nascimento et al. 2007; Moreira 2010). O conceito surgiu com Hose (1995) para conceituar o tipo de turismo que utiliza como atrativos feições geológicas diversas, tais como formações rochosas, estruturas e paisagens.

As definições originais tinham como principal característica a preocupação com a divulgação do meio físico. As abordagens mais recentes, no entanto, incluem, dentre as atividades ligadas ao geoturismo a a integração com outros aspectos do patrimônio da região. A Declaração de Arouca, desenvolvida durante o Congresso Internacional de Geoturismo, realizado em Portugal, em 2011, postula que o Geoturismo passe a ser entendido como "... o turismo que sustenta e incrementa a identidade de um território, considerando a sua geologia, ambiente, cultura, valores estéticos, patrimônio e o bem-estar dos seus residentes...", definição que se aproxima muito do conceito de Ecoturismo. 


\section{Geoparques}

Geoparques são áreas que englobam além da proteção, a valorização e divulgação do Patrimônio Geológico com o desenvolvimento sustentável local (Zouros, 2010). Segundo o mesmo autor essas áreas devem abranger um

\footnotetext{
"patrimônio geológico com características geológicas, mineralógicas, geofísicas, geomorfológicas, paleontológicas ou geográficas específicas. E devem compreender certo número de sítios geológicos de particular importância em termos de sua qualidade científica, raridade, apelo estético ou valor educacional."
}

Além disso, o patrimonio geológico associado a outros bens naturais e culturais podem atrair visitantes através de atividades educativas e geoturisticas, desempenhando um importante papel na caracterização, conservação e interpretação do patrimônio, etapas básicas para estratégias de geoconservação (Brilha, 2018).

Os georparques foram criados durante o Congresso Internacional de Geologia na China em 1996, nessa época as atividades de geoturismo já se encontravam em desenvolvimento em 4 paises França, Alemanha, Espanha e Grécia, posteriormente, em 2000 foi criada a Rede Européia de Geoparques, e a Rede Mundial de Geoparques da UNESCO em 2014 (Boggiani, 2010). Atualmente existem 127 Geoparques Mundiais distribuídos em 35 países. O Brasil possui somente um, 0 Geoparque Araripe (UNESCO).

É comum que conceito de geoparque possa ser confundido com os conceito dos parques no Brasil, pois visam a conservação ambiental, porém diferente do conceito de parque atribuído as leis brasileiras os geoparques, visam beneficiar a população, tornando os aspectos geológicos atrativos para um novo desenvolvimento econômico local associado à conservação do patrimônio natural, a valorização e preservação da cultura (Boggiani, 2010). 


\subsection{Justificativa}

Os municípios de Iguape e llha Comprida inserem-se na região mais preservada da costa paulista, nas Reservas de Mata Atlântica do Sudeste, denominadas Patrimônio Natural Mundial pela UNESCO e que se estendem por toda planície costeira, de Iguape (SP) a Paranaguá (PR). A região possui grande disponibilidade de recursos naturais fornecidos principalmente pelos ecossistemas costeiros.

A atividade econômica da região está relacionada diretamente com o meio físico, pois, além dos bens e serviços fornecidos pelos ecossistemas, a área possui grandes belezas naturais e também diversos atrativos culturais, históricos e religiosos, o que os torna cada vez mais destino de muitos turistas e consequentemente aumentam a especulação imobiliária. Esse alto crescimento turístico, aliado à falta de informação sobre as características do meio físico, coloca em risco a integridade do meio natural, incluindo muitos locais de interesse geológico que, além de constituírem-se em importantes registros do quartenário brasileiro, a região têm potencial para atividades turísticas sustentáveis e de educação formal e não-formal.

Neste contexto, cabe que medidas sejam tomadas para promover a conservação destes locais. O primeiro passo para isso deve ser o inventário, que tem como objetivo selecionar os locais mais relevantes, descrever suas características e apontar sugestões de uso. Associado à quantificação, os locais selecionados compõem uma lista seriada que estabelece prioridades de proteção e potencialidades, resultados que podem ser utilizados na valorização do patrimônio geológico. Adicionalmente, o conhecimento adequado destes locais dá margem a usos diversos, que incluem também a disseminação do conhecimento geocientífico produzido na academia para o público geral, o subsídio à organização de políticas públicas e a elaboração de futuras propostas de gestão.

Este inventário faz parte de um trabalho maior, que tem como objetivo o diagnóstico de locais de interesse geológico da região costeira do estado de São Paulo (Garcia et al. 2012, 2014, 2018, no prelo). 


\subsection{Objetivos}

O objetivo desta pesquisa é realizar o inventário dos locais de interesse geológico dos municípios de lguape e llha Comprida, litoral sul do estado de São Paulo, por meio da identificação e avaliação desses locais de acordo com os seus valores científicos, educativos e turísticos.

Como objetivos específicos, tem-se:

- Seleção dos sítios de interesse geológico;

- Identificação e descrição dos sítios selecionados;

- Avaliação e classificação dos sítios identificados;

- Quantificação dos geossítios e sítios da geodiversidade;

- Avaliação do enquadramento legal dos locais;

- Recomendações para adequada gestão, conservação e utilização sustentável;

- Sugestões para valorização turística e educativa dos locais de interesse geológico. 


\section{CARACTERIZAÇÃO DE IGUAPE E ILHA COMPRIDA}

Neste capítulo serão descritas as principais características sociais, ambientais e do meio físico dos municípios de Iguape e llha Comprida.

\subsection{Localização e acesso}

Os municípios de Iguape e llha Comprida situam-se no litoral sul do Estado de São Paulo e integram-se na região do Baixo Vale do Ribeira. Estão distantes cerca de 200 km da capital (Fig. 1). O acesso partindo-se da capital paulista é possível por meio de duas rodovias principais: pela Rodovia Régis Bittencourt até o trevo de Iguape, seguindo pela Rodovia Pref. Casimiro Teixeira (SP-222) e pela Rodovia dos Imigrantes (BR-101) até a Rod. Pref. Casemiro Teixeira. O trajeto de Iguape para Ilha Comprida pode ser feito por terra, pela ponte Prefeito Laércio Ribeiro, ou por balsa, a partir de Cananeia.

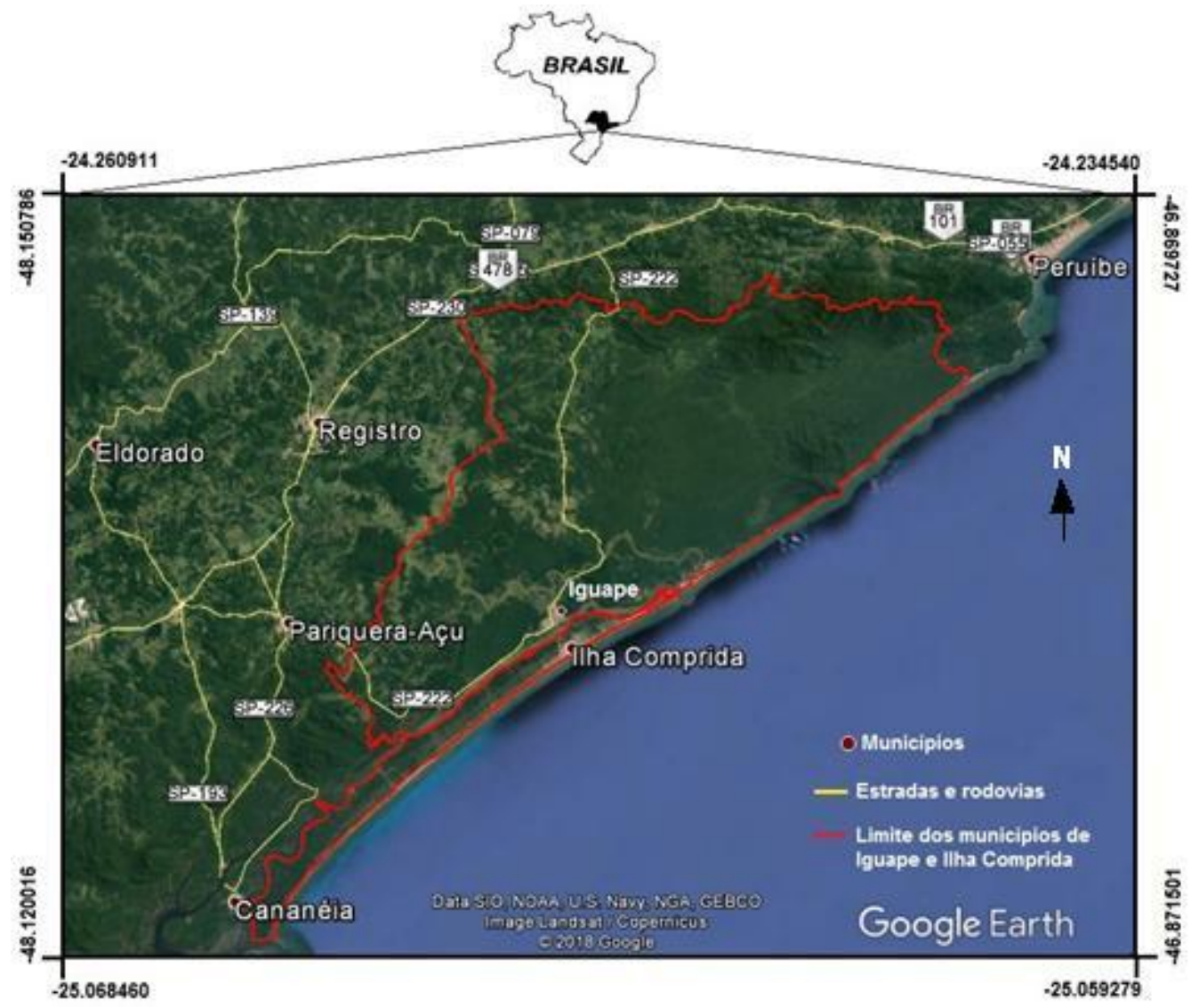

Figura 1 - Mapa de localização e acesso dos municípios de Iguape e llha Comprida, litoral sul do estado de São Paulo. 


\subsection{Aspectos do meio físico}

A região de estudo insere-se no sistema estuarino-lagunar Cananeia-Iguape, que integra-se ao mais extenso domínio de sedimentação terrígena quaternária do estado de São Paulo e é formado por sedimentos costeiros.

\subsubsection{Contexto Geomorfológico}

A área de estudo desse trabalho insere-se, segundo Almeida (1964, p.200), na Província Costeira, que está dividida em duas zonas geomorfológicas: a serrania costeira e a baixadas litorâneas. A serrania costeira abrange uma faixa de direção E$\mathrm{W}$, com aproximadamente $50 \mathrm{~km}$ de comprimento e $10 \mathrm{~km}$ de largura. É composta principalmente por rochas gnáissicas ao longo da bacia do Ribeira de Iguape (Bentz, 2004).

Segundo Souza e Souza (2002), essa faixa é denominada Morros e Serras e é representada pelas unidades de relevo como Serra do Bananal, Serra dos Itatins e Serra de Peruíbe e também por unidades isoladas na porção central, como a Serra da Jureia e os morros do Maceno-Itu e do Espia.

A Serra de Itatins refere-se ao bloco soerguido de uma falha normal de direção NE e encontra-se aproximadamente $500 \mathrm{~m}$ acima das serras do Bananal, com altitudes máximas de 620 a $679 \mathrm{~m}$, num relevo com montanhas e vales profundos, entre os municípios de Miracatu e Iguape. Ambas são exemplos da tectônica cenozoica que ocorreu na região (Souza e Souza, 2002). A Serra da Jureia caracteriza-se por um maciço isolado de relevo montanhoso, com altitude máxima de $870 \mathrm{~m}$.

Nas baixadas litorâneas os tipos mais frequentes de relevo são as planícies costeiras e os terraços marinhos. A baixada do rio Ribeira de Iguape é constituída por praias extensas e restingas, localmente recobertas por dunas (Souza e Souza, 2002).

Na llha Comprida há somente uma elevação, o Morrete, que se encontra na ponta sudoeste da ilha, com 42 metros de altura, formado por rochas alcalinas neocretáceas como quartzo-sienito (Spinelli, 2007). Suguio e Petri (1973) apontaram alguns morros mais próximos à área urbana da cidade de lguape, como o Morro da Paixão, o mais alto, com 500 m, o Morro dos Engenhos, o Morro do Icapara e o 
Morro do Espia.

\subsubsection{Contexto geológico}

A área de estudo desse trabalho, a região sul do litoral do estado de São Paulo, encontra-se no segmento central do cinturão Ribeira, uma das entidades geotectônicas pré-cambrianas da Província Mantiqueira, originada durante o evento Brasiliano-Pan Africano que consolidou o paleocontinente Gondwana Ocidental (Fig. 2) (Heibron et al., 2004; Almeida et al., 1977).

Durante o Mesozoico, houve a ruptura do supercontinente Gondwana, o que resultou na abertura do Oceano Atlântico Sul e posterior desenvolvimento da atual margem continental atlântica (Almeida et al., 1977). Um dos registros mais significativos dos eventos de abertura é o alinhamento Guapiara, uma faixa de direção NW com cerca de $600 \mathrm{~km}$ de extensão que alcança o litoral de Iguape e se caracteriza por fraturas, falhas e numerosos diques de diabásio com direção NW que cortam as rochas metamórficas e graníticas mais antigas de idade précambriana. Esta feição é considerada o principal fator que controlou a abertura do vale do rio Ribeira de Iguape (Souza e Souza, 2002; Almeida e Carneiro 1998).

Durante a abertura do Oceano Atlântico Sul houve a formação de áreas de sedimentação no continente e na plataforma continental. Ao final dessa sedimentação ocorreram vários episódios de mudanças climáticas e erosivas predeterminantes do cenário costeiro que iria receber regressões e transgressões marinhas quaternárias responsáveis pela atual configuração do sistema lagunar da região (Ab'Saber, 2007).

Essas unidades litoestratigráficas cenozoicas cobrem a maior parte da região e incluem predominantemente sedimentos arenosos do Pleistoceno (formações Pariquera-açu e Cananeia -Suguio e Petri, 1973) e do Holoceno (Formação Ilha Comprida, com 5,5 mil anos, esses últimos com evidências de sambaquis - Suguio e Martin, 1978) (Fig.3).

Os sedimentos da Formação Pariquera-Açu estão ligados à reativação das falhas normais, associadas ao arqueamento Guapiara. Abrangem depósitos de leques aluviais, depósitos de planície fluvial meandrante e lacustres (Melo, 1990). 


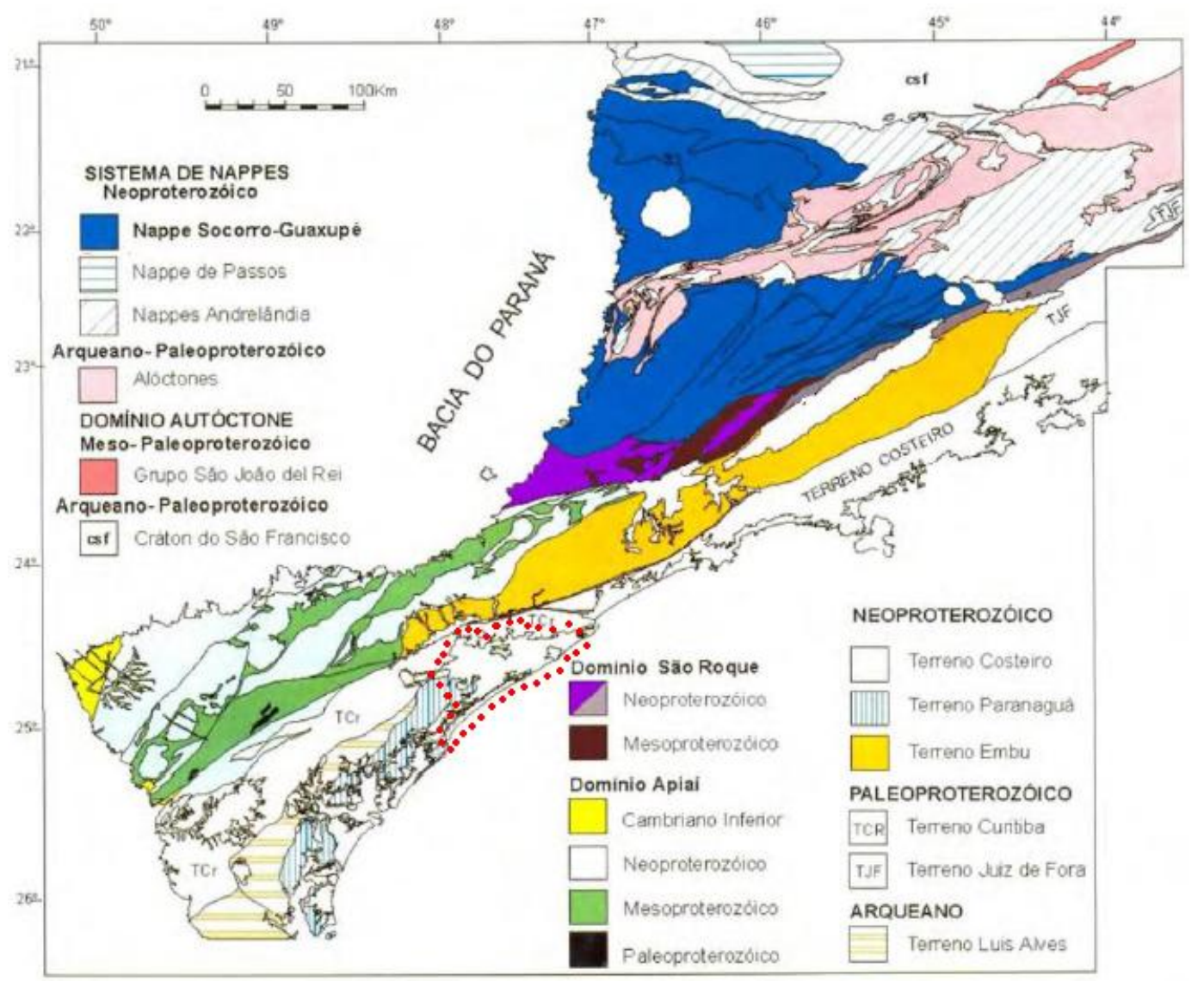

Figura 2 - Mapa tectônico dos terrenos Apiaí, Guaxupé, Curitiba, Embu e Luís Alves. O polígono pontilhado vermelho corresponde à área de estudo (adaptado de HEILBRON et al., 2004).

A Formação Cananeia foi denominada por Suguio e Petri (1973), que reconheceram quatro sequências litológicas, da base para o topo: I - camadas arenosas e conglomeráticas (relacionadas à formação Pariquera-Açu), II sedimentos síltico-argilosos, III - areias siltosas e IV - areias finas muito bem selecionadas, cimentadas por material ferruginoso localmente conhecido como "picarras". As sequências I, II, III são relacionadas ao período transgressivo e a sequência IV, à época regressiva. Esta formação está presente por toda extensão do litoral sul paulista e relaciona-se ao evento da Transgressão Cananeia.

A Formação Ilha Comprida, segundo Suguio e Martin (1994), estão associados a areias marinhas holocênicas finas a muito finas, que estão dispostas sob a forma de cordões litorâneos e apresentam dunas eólicas de diferentes tipos e gerações. A llha Comprida é composta essencialmente por cordões litorâneos e seu desenvolvimento, com ou sem dunas frontais, depende, segundo Hesp, (2002 apud Guedes, 2009 p. 114) "de fatores como volume, granulometria da área suprida, 
vegetação, regime de ventos e ondas, morfodinâmica da praia, variação do NRM e estabilidade da linha de costa". O mesmo autor afirma que qualquer alteração nesses fatores pode modificar o tipo de cordão formado e causar o retrabalhamento sedimentar. A análise dessas feições é de grande importância para compreender os processos sedimentares ao longo do tempo e de seus fatores controladores, tais como aporte sedimentar e variação do nível relativo do mar.

Os cordões que foram estabilizados por vegetação mostram, em alguns pontos da ilha, principalmente na parte central, rupturas de deflação (blowouts), que são feições erosivo-deposicionais geradas por retirada da vegetação via deflação e redeposição local pelo vento (Giannini et al 2005). O maior período de atividade dessas rupturas possui idades correlacionáveis com a Pequena Idade do Gelo (1450-1850 d.c) (Guedes, 2009).

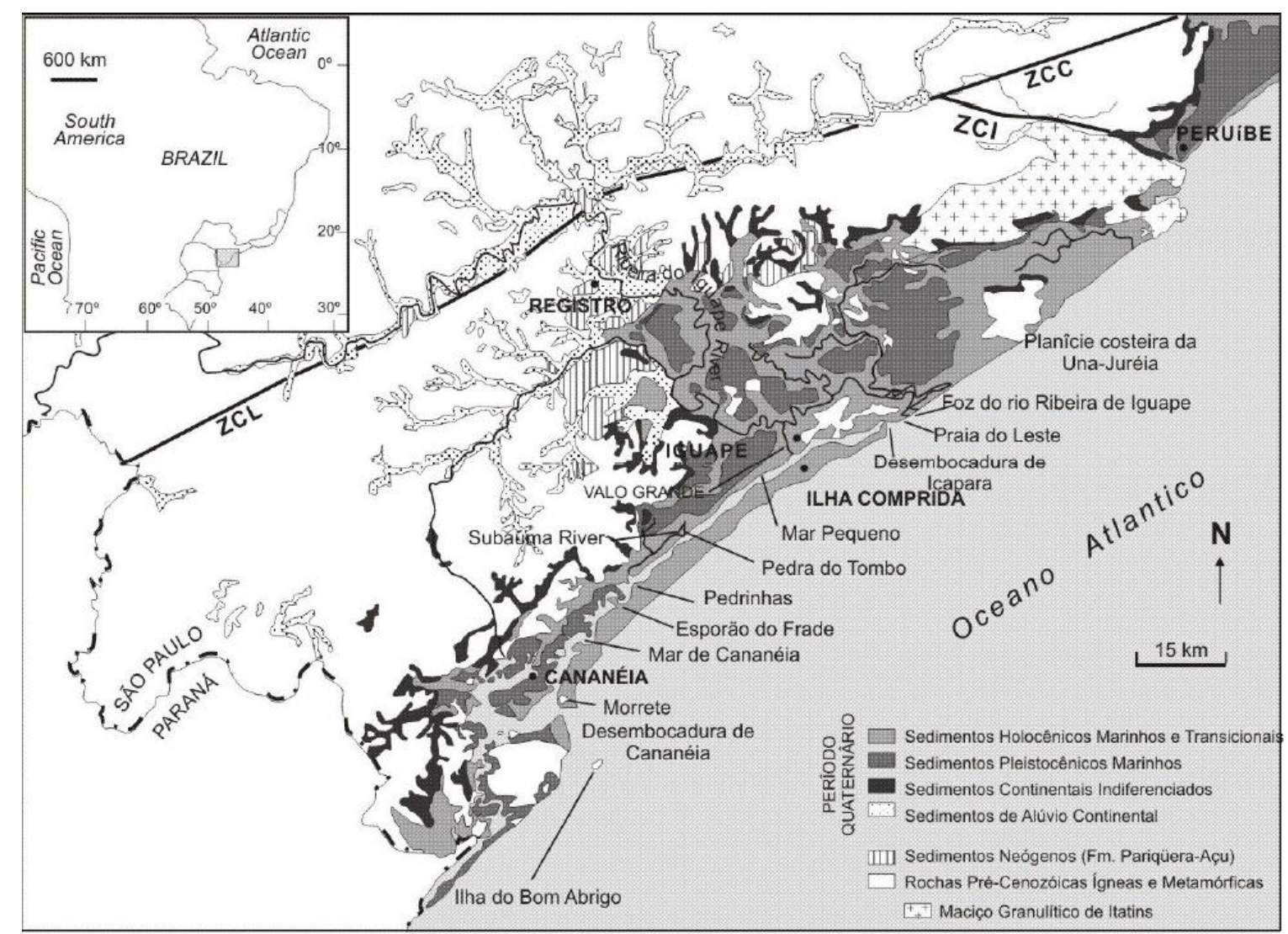

Figura 3 - Mapa geológico da região, com destaque para as formações do período quaternário. ZCL- Zona de Cisalhamento Lancinha; ZCC- Zona de Cisalhamento Cubatão; ZCI Zona de Cisalhamento Itariri. (Guedes, 2009). 


\subsection{Aspectos socioeconômicos e culturais}

Iguape é o maior município do estado, com uma área de 1.977,96 km². De acordo com o último senso do IBGE, em 2010 a população totalizava 28.841 habitantes. Assim a densidade demográfica desse município é $14.58 \mathrm{hab} / \mathrm{km}^{2}$ e seu IDH é 0,726. O município de llha Comprida, que fazia parte de Iguape, alcançou sua emancipação política em 05/03/1992, ano em que recebeu a condição de Estância Balneária. Possui uma área de $192,09 \mathrm{~km}^{2}$ e sua população é estimada em 9.025 habitantes, segundo o mesmo senso. A densidade demográfica é de $47 \mathrm{hab} / \mathrm{km}^{2}$ e 0 IDH, 0,725.

A região também é habitada por comunidades tradicionais como caiçaras, quilombolas e indígenas. Segundo Diegues (1997), a cultura caiçara mistura elementos negros, indígenas e europeus. Na região de Iguape e llha Comprida há comunidades ainda existentes. Em Iguape as principais são as comunidades do Prelado, da Enseada, de Sorocabinha, do Sete Belo, e da Ilha Grande. Em Ilha Comprida estão as comunidades do Araçá, de Arthur de Ramos, de Ubatuba, de Pedrinhas, de Juruvaúva, do Boqueirão Sul e do Boqueirão Norte, esse último concentrando grande parte da população da ilha e onde situa-se a sede administrativa (MMA, 2016).

O inicio da massiva ocupação da região se deu de forma lenta e gradual ao longo de 6000 A.P, período em que se têm os vestígios dos primeiros habitantes da região. Os vestígios dizem respeito aos "sambaquis", que são depósitos compostos por montes de conchas de moluscos nos quais frequentemente são encontrados ossos humanos e objetos. Esses vestígios constituem o patrimônio arqueológico da região e são importantes para compreender a configuração da paisagem daquela época. A ocorrência dos sambaquis comprova que o local escolhido pelos antigos habitantes situava-se junto à costa na época, mas atualmente encontra-se a $30 \mathrm{~km}$ de distância da orla, evidenciando o processo de variação do nível do mar (Scatamacchia, 2004). Esses habitantes são denominados "homens do sambaqui" e não conheciam o arco-e-flecha.

Após a fase de ocupação primitiva tem início a dos colonizadores europeus, que tem importante papel histórico no período das primeiras expedições da costa 
brasileira. No século XVI instalaram-se os povoados que viriam a constituir lguape e Cananeia.

Por volta de 1502 a Armada do espanhol Américo Vespúcio deixa na llha do Bom Abrigo, em Cananeia, o degradado Cosme Fernandes "O Bacharel", que teria sido capturado pelos índios Tupis em uma expedição para Ilha Comprida. Após ganhar a confiança dos índios, casa-se com a filha do cacique Ariró (Carvalho, 1999; Prefeitura de Ilha Comprida).

Em meados de 1531, Martin Afonso de Souza foi enviado por Dom João III para garantir interesses da coroa portuguesa na região, instalando-se inicialmente na Ilha do Bom Abrigo. A comitiva toda foi recebida pelo Bacharel, que Ihes apresentou a llha Comprida e escolhe a Vila de Maratayama ${ }^{1}$ ou Vila dos Tupis como sede da primeira vila oficial da Coroa Portuguesa. Esse povoado teria durado cerca de 80 anos (Becegato e Suguio, 2007; Prefeitura de llha Comprida). Com a instalação dos europeus formou-se também o primeiro povoado de Iguape, localizado onde hoje é o bairro do Icapara.

Mais tarde, em 1534, chega à Ilha Comprida Rui Garcia de Mosquera, responsável por construir um forte que leva o seu nome no Pontal da Trincheira que, atualmente, encontra-se totalmente destruído (Carvalho, 1999).

No final do século XVII a vila de Iguape muda-se da região do bairro do Icapara para a área na qual está localizada atualmente. Nesta época foi descoberto, nos afluentes do rio Ribeira de Iguape, o ouro de lavagem, iniciando-se assim o primeiro ciclo econômico da região. Graças à abundância do ouro, a mineração intensificou-se, surgindo então a primeira Oficina Real de Fundição de Ouro do Brasil. Este ciclo do ouro não se perpetuou por muito tempo e, no início do século $\mathrm{XVIII}$, as empresas exploradoras instaladas na região migraram gradualmente para Minas Gerais por conta do crescimento das atividades mineradoras neste estado, o que resultou numa emigração populacional significativa e na transformação de Iguape em uma vila humilde e pacata (Pereira Junior, 2005).

Entre o final do século XVIII e o início do século XIX, o ciclo do arroz destacou a vila de Iguape como uma das mais importantes do Império, sendo o seu porto um dos maiores do país. A criação do porto deu origem ao Valo Grande, um canal artificial criado para facilitar o transporte de mercadorias e que acarretou em

\footnotetext{
${ }^{1}$ Maratayama na língua tupi significa "terra do mar" (BECEGATO, 2007).
} 
diversos impactos e mudanças na paisagem da região, tornando Iguape uma ilha fluvial. Esse caso será detalhado no item 2.3.3.

A cidade de lguape ainda possui construções dos séculos XVII e XVIII. A arquitetura apresenta uma mistura de técnicas brasileiras, uma das quais utilizava conchas dos sambaquis, que foram chamados de ostreiros pelos colonizadores e transformados em cal para construções, técnica chamada de berbigão. Até hoje Iguape possui casas, casarões e igrejas que se tornaram patrimônio histórico e cultural e o centro histórico foi tombado pelo Iphan em 2011 (Nascimento e Scifoni, 2011).

A administração de llha Comprida foi dividida, em 1958, entre os municípios de Cananeia e Iguape. A porção norte, cerca de $70 \%$ da ilha, ficou com Iguape e a porção sul (30\%), com Cananeia. A especulação imobiliária da ilha teve inicio em 1950, data a partir da qual a ilha foi se transformando em um polo turístico. Em 1987, foi criada a APA Ilha Comprida (Becegato e Suguio, 2007).

\subsection{Aspectos socioambientais}

A região insere-se na bacia hidrográfica do rio Ribeira de Iguape, que tem suas desembocaduras a nordeste - desembocadura de Icapara e a sul da llha Comprida - desembocadura do Mar Pequeno.

A vegetação é caracterizada em sua maior parte pelo bioma da Mata Atlântica e possui alta diversidade de espécies animais, muitos de hábito migratório, e vegetais, que são associados aos ecossistemas costeiros como mangue, restinga, duna, estuário, laguna, costão rochoso e praia, que têm relação direta com a geodiversidade.

Pela importância desses ecossistemas tanto para a vida animal quanto para a vida humana, a área é protegida por diferentes unidades de conservação.

O clima da região insere-se na faixa de transição entre os climas tropical e subtropical, encontra-se sob a influência da Zona de Convergência do Atlântico Sul (ZCAS). O clima local predomina quente e úmido devido à proximidade do oceano, a dinâmica atmosférica regional, e as formas de relevo, caracterizados por altas temperaturas, umidade elevada e altos índices pluviométricos. (MAGALHÂES, 2003) 


\subsubsection{O Valo Grande}

Após a queda do ciclo do ouro na região de Iguape, o ciclo do arroz teve seu auge e serviu para consolidar a construção do porto de Iguape, na época o mais importante do estado de São Paulo. Para facilitar o transporte da produção agrícola e mineral da região ao longo do rio ribeira de Iguape, o maior curso fluvial do litoral paulista, até o porto, foi construído por volta de 1857 um canal artificial denominado Valo Grande (Giannini et al. 2018).

O canal, que tinha inicialmente cerca de 4 metros de largura alcança, atualmente, em alguns locais, cerca de 300 metros, tornando Iguape uma ilha fluvial. A abertura do valo ocasionou consequências hidrodinâmicas, geomorfológicas, sedimentológicas e sobre os ecossistemas, afetando a dinâmica da região por meio do acelerado assoreamento do rio Ribeira de Iguape e de mudanças na extremidade NE da Ilha Comprida. O intenso aporte de sedimentos ocasionou a formação de pequenas ilhas, de um delta na desembocadura do rio e no crescimento acelerado da Ilha Comprida, resultando no desaparecimento da praia do Leste, em Iguape (Gianinni et al., 2018; Nascimento, 2006). Devido a esses acontecimentos, o município de lguape teve um alto prejuízo econômico.

$\mathrm{O}$ assoreamento do rio também começou a impedir as navegações e a atracação da balsa, o que levou à construção da ponte rodoviária que interliga Iguape a llha Comprida, em 1984. Porém, devido aos impactos ambientais gerados, foi interrompida em 1991. Após apresentar propostas de regularização, a prefeitura da Ilha Comprida, que acabara de se emancipar, solicitou uma licença para retomar as obras. A ponte foi inaugurada em 2000 (Becegato e Suguio, 2007). 


\section{METODOLOGIA}

A qualidade dos dados obtidos nas etapas iniciais de qualquer estratégia de geoconservação (i.e., inventário e avaliação quantitativa) é essencial para o sucesso das ações subsequentes. Por esta razão, o inventário deve ser realizado de forma sistemática e com critérios bem definidos, de modo a garantir a seleção de locais realmente relevantes de acordo com os objetivos da pesquisa. Do mesmo modo, a avaliação quantitativa deve conter a menor subjetividade possível, para que os resultados possam, efetivamente, subsidiar ações de conservação e uso.

\subsection{Para o inventário de locais de interesse geológico}

Neste trabalho, utiliza-se a metodologia de Brilha (2016) para o inventário de locais de interesse geológico.

\subsubsection{Pesquisas iniciais}

Nesta etapa foram utilizadas informações coletadas sobre a área de estudo por meio de análises de mapas, teses, artigos, dissertações, imagens de satélite (Google Earth), reportagens e consultas a pesquisadores que já trabalharam na região. Utiliza-se como base cartográfica o Mapa Geológico do estado de São Paulo (PERROTTA et al., 2005).

\subsubsection{Seleção dos locais potenciais}

Com base na etapa anterior foi elaborada uma lista preliminar com 26 locais potenciais, selecionados com base em sua representatividade dentro da história geológica da região. Informações básicas sobre estes locais, incluindo localização e acesso, foram incluídas para facilitar as atividades de campo.

\subsubsection{Trabalho de campo}

Para investigar e caracterizar os potenciais locais de interesse geológico selecionados na etapa anterior, foram realizadas duas viagens de campo, em fevereiro e março de 2017, para a área de estudo, totalizando 6 dias de trabalho e 26 locais visitados. 
A visita aos locais situados em unidade de conservação permanente, como é o caso da Estação Ecológica Jureia-Itatins, foi feita por meio de um pedido de autorização prévia e agendamento de guia, com a administração da unidade.

A área de estudo possui paisagens bem diversificadas, por isso os sítios selecionados localizam-se em diferentes locais como praias, dunas, costões, trilhas, cachoeiras, morros e estradas. Sendo uma região em crescimento demográfico, alguns locais não foram encontrados, pois foram parcialmente ou totalmente destruídos por ação antrópica.

Os sítios pré-selecionados foram descritos quanto aos seus aspectos geológicos e estruturais, geomorfológicos, biológicos, históricos e culturais. A localização foi feita utilizando GPS para obter as coordenadas (geográfica e UTM). Além disso, os locais foram fotografados para registrar as principais feições e foram retiradas amostras para análise mais detalhada (quando cabíveis). O ambiente de entorno também foi avaliado em relação a condições de observação, acesso, infraestrutura e possíveis ameaças naturais e antrópicas.

\subsubsection{Lista final}

A lista final foi determinada após os trabalhos de campo. A seleção levou em conta principalmente a representatividade, a integridade das principais feições geológicas e as limitações de uso. Ao todo, 12 locais foram selecionados.

A classificação tipológica para os geossítios e o sítio da geodiversidade foi feita de acordo com Fuertes-Gutiérrez e Fernández-Martínez (2010). O risco de degradação foi avaliado conforme Garcia-Ortiz et al. (2014) quanto à fragilidade e à vulnerabilidade natural e antrópica.

\subsection{Para a avaliação quantitativa}

A avaliação quantitativa dos locais de interesse geológico dos municípios de Iguape e llha Comprida foram feitos a partir da plataforma GEOSSIT, desenvolvida pelo Serviço Geológico do Brasil (CPRM) - Rocha et al. (2016). A plataforma utiliza como base as metodologias de Brilha (2016) e Garcia-Cortés e Carcavilla-Urquí (2009). 


\subsubsection{Critérios}

Os critérios utilizados para essa avaliação levam em conta o valor científico, o risco de degradação e o potencial de uso educativo e turístico.

O valor científico é avaliado por sete parâmetros, em que cada um recebe os valores de $0,1,2$ ou 4, (Tabela 2). Na avaliação do risco de degradação, cinco parâmetros foram estabelecidos, com valores que variam de 0 a 4 (Tabela 2). A avaliação quantitativa do potencial de uso educativo é avaliada por doze parâmetros e o de uso turístico, por treze, com valores de 0 a 4 (Tabela 3). Para cada parâmetro é atribuído um peso que será apresentado nas tabelas 4, 5, 6 e 7.

Tabela 1 - Parâmetros utilizados para avaliação quantitativa do valor científico de locais de interesse geológico de acordo com Rocha et al. (2016).

\section{Critérios do valor científico}

\section{A1 - Representatividade}

O local de interesse é o melhor exemplo, atualmente conhecido, na área de trabalho, para ilustrar elementos ou processos, relacionados com a área temática em questão (quando aplicável).

O local de interesse é um bom exemplo para ilustrar elementos ou processos, relacionados com a área temática em questão (quando aplicável).

O local de interesse ilustra razoavelmente elementos ou processos, relacionados com a área temática em questão (quando aplicável).

Não se aplica.

\section{A2 - Local-tipo}

O local é reconhecido como holostratótipo ou unidade litodêmica nos léxicos estratigráficos do Brasil e da Amazônia Legal ou documentos similares, ou é a fonte de um holótipo, neótipo ou lectótipo registrado em publicações científicas, de acordo com o código (ICZN, ICBN ou ICN) vigente na época da descrição e cadastrado na Base de Dados Paleo da CPRM ou bases similares ou é um sítio de referência da IMA;

O local de interesse é reconhecido, na área de trabalho, como local-tipo secundário, sendo a fonte de um paratrastótipo, unidade litodêmica ou de um parátipo.

O local de interesse é reconhecido, na área de trabalho, como um dos locais-tipo secundários, sendo a fonte de um ou mais paratrastótipo, unidade litodêmica, parátipo ou sintipo.

Não se aplica.

\section{A3 - Conhecimento científico}

Existem artigos sobre o local de interesse em livro, em revistas científicas internacionais, diretamente relacionados com a categoria temática em questão (quando aplicável).

Existem artigos sobre o local de interesse em revistas científicas nacionais, diretamente relacionados com a categoria temática em questão (quando aplicável).

Existem resumos apresentados sobre o local de interesse em anais de eventos científicos, ou em relatórios inéditos, diretamente relacionados com a categoria temática em questão (quando aplicável).

Não se aplica.

\section{A4 - Integridade}

Os principais elementos geológicos (relacionados com a categoria temática em questão, quando aplicável) estão muito bem preservados.

O local de interesse não está muito bem preservado, mas os principais elementos geológicos (relacionados com a categoria temática em questão, quando aplicável) ainda estão preservados.

O local de interesse não está muito bem preservado, mas os principais elementos geológicos (relacionados com a categoria temática em questão, quando aplicável) ainda estão preservados. 
Continuação...

Local de interesse com 3 ou 4 tipos diferentes de aspectos geológicos com relevância científica.

Local de interesse com 1 ou 2 tipos diferentes de aspectos geológicos com relevância científica.

Não se aplica.

A6 - Raridade

O local de interesse é a única ocorrência deste tipo na área de estudo (representando a categoria

temática em questão, quando aplicável).

Existem, na área de estudo, 2-3 exemplos de locais semelhantes (representando a categoria temática em questão, quando aplicável).

Existem, na área de estudo, 4-5 exemplos de locais semelhantes (representando a categoria temática em questão, quando aplicável).

Não se aplica.

A7 - Limitações ao uso

\begin{tabular}{|c|}
\hline 2 \\
\hline 1 \\
\hline Valor \\
\hline 4 \\
\hline 2 \\
\hline 1 \\
\hline 0 \\
\hline Valor \\
\hline 4 \\
\hline 2 \\
\hline 1 \\
\hline 0 \\
\hline
\end{tabular}

Não existem limitações (necessidade de autorização, barreiras físicas, etc.) para realizar amostragem ou trabalho de campo.

É possível fazer amostragem ou trabalho de campo depois de ultrapassar as limitações existentes.

A realização de amostragem ou trabalho de campo é muito difícil de ser conseguida devido à existência de limitações (necessidade de autorização, barreiras físicas, etc.).

Não se aplica.

Tabela 2 - Parâmetros utilizados para avaliação quantitativa do uso educativo e turístico de locais de interesse geológico de acordo com Rocha et al. (2016).

\section{C1 - Vulnerabilidade}

\section{Critérios do potencial uso educativo e turístico}

Os elementos geológicos do local de interesse não apresentam possibilidade de deterioração por atividades antrópicas

Possibilidade de deterioração de elementos geológicos secundários por atividade antrópica

Possibilidade de deterioração dos principais elementos geológicos por atividade antrópica

Possibilidade de deterioração de todos elementos geológicos por atividade antrópica

Não se aplica.

C2 - Acessibilidade

Local de interesse localizado a menos de $100 \mathrm{~m}$ de uma estrada asfaltada com local para estacionamento

Local de interesse localizado a menos de $500 \mathrm{~m}$ de uma estrada asfaltada

Local de interesse acessível por veículo em estrada não asfaltada

Local de interesse sem acesso direto por estrada, mas situado a menos de $1 \mathrm{~km}$ de uma estrada

acessível por veículo

Não se aplica.

C3 - Limitações de uso

O local de interesse não tem limitações para ser usado por estudantes e turistas

O local de interesse pode ser usado por estudantes e turistas, mas apenas ocasionalmente

O local de interesse pode ser usado por estudantes e turistas, mas só depois de ultrapassar certas

limitações (autorização, barreiras físicas, marés, inundações, etc.)

O uso por estudantes e turistas é muito difícil de conseguir devido à dificuldade em ultrapassar certas limitações (autorização, barreiras físicas, marés, inundações, etc.)

Não se aplica.

C4 - Segurança

Local de interesse com infraestrutura de segurança (vedações, escadas, corrimões, etc.), rede de comunicações móveis e situado a menos de $10 \mathrm{~km}$ de serviços de socorro

Local de interesse com infraestrutura de segurança (vedações, escadas, corrimões, etc.), rede de comunicações móveis e situado a menos de $25 \mathrm{~km}$ de serviços de socorro 
Continuação...

Critérios do potencial uso educativo e turístico

Local de interesse sem instalações de segurança (vedações, escadas, corrimões, etc.), mas com rede de comunicações móveis e situado a menos de $50 \mathrm{~km}$ de serviços de socorro

Local de interesse sem instalações de segurança (vedações, escadas, corrimões, etc.) nem rede de comunicações móveis e situado a mais de $50 \mathrm{~km}$ de serviços de socorro

Não se aplica.

C5 - Logística

Existem restaurantes e alojamentos para grupos de 50 pessoas a menos de $15 \mathrm{~km}$ do local de interesse

Existem restaurantes e alojamentos para grupos de 50 pessoas a menos de $50 \mathrm{~km}$ do local de interesse

Existem restaurantes e alojamentos para grupos de 50 pessoas a menos de $100 \mathrm{~km}$ do local de interesse

Existem restaurantes e alojamentos para grupos de até 25 pessoas a menos de $50 \mathrm{~km}$ do local de interesse

Não se aplica.

\section{C6 - Densidade populacional}

Local de interesse localizado num município com mais de 1000 habitantes por km.

Local de interesse localizado num município com 250-1000 habitantes por km.

Local de interesse localizado num município com 100-250 habitantes por km.

Local de interesse localizado num município com menos de 100 habitantes por $\mathrm{km}$.

Não se aplica.

\section{C7 - Associação com outros valores}

Existem diversos valores ecológicos e culturais a menos de $10 \mathrm{~km}$ do local de interesse

Existem diversos valores ecológicos e culturais a menos de $20 \mathrm{~km}$ do local de interesse

Existe um valor ecológico e um cultural a menos de $20 \mathrm{~km}$ do local de interesse

Existe um valor ecológico ou um cultural a menos de $20 \mathrm{~km}$ do local de interesse

Não se aplica.

\section{C8 - Beleza cênica}

Local de interesse habitualmente usado em campanhas turísticas do país, mostrando aspectos geológicos

Local de interesse ocasionalmente usado em campanhas turísticas do país, mostrando aspectos geológicos

Local de interesse habitualmente usado em campanhas turísticas locais, mostrando aspectos geológicos

Local de interesse ocasionalmente usado em campanhas turísticas locais, mostrando aspectos geológicos

Não se aplica.

\section{C9 - Singularidade}

Ocorrência de aspectos únicos e raros no país

Ocorrência de aspectos únicos e raros no estado

Ocorrência de aspectos únicos e raros na região

Ocorrência de aspectos comum nas várias regiões do país

Não se aplica.

\section{C10 - Condições de observação}

A observação de todos os elementos geológicos é feita em boas condições

Existem obstáculos que tornam difícil a observação de alguns elementos geológicos

Existem obstáculos que tornam difícil a observação dos principais elementos geológicos

Existem obstáculos que praticamente impossibilitam a observação dos principais elementos geológicos

Não se aplica.

C11 - Potencial didático

Ocorrência de elementos geológicos que são ensinados em todos os níveis de ensino 
Continuação...

Ocorrência de elementos geológicos que são ensinados nas escolas de ensino básico

Ocorrência de elementos geológicos que são ensinados nas escolas de ensino secundário

Ocorrência de elementos geológicos que são ensinados no ensino superior

Não se aplica.

C12 - Diversidade geológica

Ocorrem mais de 5 tipos de elementos da geodiversidade (mineralógicos, paleontológicos, geomorfológicos, etc.)

Ocorrem 3 ou 4 tipos de elementos da geodiversidade

Ocorrem 2 tipos de elementos da geodiversidade

Ocorre apenas 1 tipo de elemento da geodiversidade

Não se aplica.

C13 - Potencial para divulgação

Ocorrência de elementos geológicos que são evidentes e perceptíveis para todos os tipos de púbicos

O público necessita de algum conhecimento geológico para entender os elementos geológicos que ocorrem no sítio

O público necessita de bons conhecimentos geológicos para entender os elementos geológicos que ocorrem no sítio

Os elementos geológicos que ocorrem no sítio apenas são evidentes e perceptíveis para quem possui graduação em geociências

Não se aplica.

C14 - Nível econômico

Local de interesse localizado num município com pelo menos o dobro do IDH que se verifica no estado

Local de interesse localizado num município com IDH superior ao que se verifica no estado

Local de interesse localizado num município com IDH idêntico ao que se verifica no estado

Local de interesse localizado num município com IDH inferior ao que se verifica no estado

Não se aplica.

C15 - Proximidade a zonas recreativas

Local de interesse localizado a menos de $5 \mathrm{~km}$ de uma zona recreativa ou com atrações turísticas

Local de interesse localizado a menos de $10 \mathrm{~km}$ de uma zona recreativa ou com atrações turísticas

Local de interesse localizado a menos de $15 \mathrm{~km}$ de uma zona recreativa ou com atrações turísticas

Local de interesse localizado a menos de $20 \mathrm{~km}$ de uma zona recreativa ou com atrações turísticas

Não se aplica.

Tabela 3 - Parâmetros utilizados para avaliação quantitativa do risco de degradação de locais de interesse geológico de acordo com Rocha et al. (2016).

\begin{tabular}{|l|c|}
\hline \multicolumn{1}{|c|}{ Critérios do risco de degradação } & Valor \\
\hline B1 - Deterioração de elementos geológicos & 4 \\
\hline Possibilidade de deterioração de todos os elementos geológicos. & 3 \\
\hline Possibilidade de deterioração dos principais elementos geológicos. & 2 \\
\hline Possibilidade de deterioração dos elementos geológicos secundários. & 1 \\
\hline Existem reduzidas possibilidade de deterioração dos elementos geológicos secundários. & 0 \\
\hline Não se aplica. & Valor \\
\hline B2 - Proximidade a áreas/atividades com potencial para causar degradação & 4 \\
\hline $\begin{array}{l}\text { Local de interesse situado a menos de 100 m de área/atividade com potencial para causar } \\
\text { degradação. }\end{array}$ & 4 \\
\hline
\end{tabular}

Continua.. 
Continuação.

\begin{tabular}{|l|c|}
\hline \multicolumn{1}{|c|}{ Critérios do risco de degradação } & Valor \\
\hline $\begin{array}{l}\text { Local de interesse situado a menos de } 500 \mathrm{~m} \text { de área/atividade com potencial para causar } \\
\text { degradação. }\end{array}$ & 3 \\
\hline $\begin{array}{l}\text { Local de interesse situado a menos de } 1000 \mathrm{~m} \text { de área/atividade com potencial para causar } \\
\text { degradação. }\end{array}$ & 2 \\
\hline $\begin{array}{l}\text { Local de interesse situado a mais de } 1000 \mathrm{~m} \text { de área/atividade com potencial para causar } \\
\text { degradação. }\end{array}$ & 1 \\
\hline Não se aplica. & 0 \\
\hline B3 - Proteção legal & Valor \\
\hline Local de interesse situado numa área sem proteção legal nem controle de acesso. & 4 \\
\hline Local de interesse situado numa área sem proteção legal, mas com controle de acesso. & 3 \\
\hline Local de interesse situado numa área com proteção legal, mas sem controle de acesso. & 2 \\
\hline Local de interesse situado numa área com proteção legal e com controle de acesso. & 1 \\
\hline Não se aplica. & 0 \\
\hline B4 - Acessibilidade & Valor \\
\hline $\begin{array}{l}\text { Local de interesse localizado a menos de 100 m de uma estrada asfaltada com local para } \\
\text { estacionamento de veículos }\end{array}$ & 4 \\
\hline Local de interesse localizado a menos de 100 m de uma estrada asfaltada. & 3 \\
\hline Local de interesse acessível por veículo em estrada não asfaltada. & 2 \\
\hline $\begin{array}{l}\text { Local de interesse sem acesso direto por estrada mas situado a menos de 1 km de uma estrada } \\
\text { acessível. }\end{array}$ & 1 \\
\hline Não se aplica. & 0 \\
\hline B5 - Densidade populacional & Valor \\
\hline Local de interesse localizado num município com mais de 1000 habitantes por km. & 4 \\
\hline Local de interesse localizado num município com 250-1000 habitantes por km. & 3 \\
\hline Local de interesse localizado num município com 100-250 habitantes por km. & 2 \\
\hline Local de interesse localizado num município com menos de 100 habitantes por km. & 1 \\
\hline Não se aplica. & 0 \\
\hline
\end{tabular}

Tabela 4 - Pesos atribuídos para avaliação quantitativa do valor científico de acordo com Rocha et al. (2016).

\begin{tabular}{|c|c|c|}
\hline & Critérios & Peso \\
\hline A1 & Representatividade & $30 \%$ \\
\hline A2 & Local-tipo & $20 \%$ \\
\hline A3 & Conhecimento científico & $5 \%$ \\
\hline A4 & Integridade & $15 \%$ \\
\hline A5 & Diversidade geológica & $5 \%$ \\
\hline A6 & Raridade & $15 \%$ \\
\hline A7 & Limitações ao uso & $10 \%$ \\
\hline & Total & $100 \%$ \\
\hline
\end{tabular}

Adaptado da metodologia de Brilha (2016) 
Tabela 5 - Pesos atribuídos para avaliação quantitativa do risco de degradação de acordo com Rocha et al. (2016).

\begin{tabular}{|c|c|c|}
\hline & Critérios & Peso \\
\hline B1 & Deterioração de elementos geológicos & $35 \%$ \\
\hline B2 & Proximidade a áreas/atividades com potencial para causar degradação & $20 \%$ \\
\hline B3 & Proteção legal & $20 \%$ \\
\hline B4 & Acessibilidade & $15 \%$ \\
\hline B5 & Densidade populacional & $10 \%$ \\
\hline & Total & $100 \%$ \\
\hline
\end{tabular}

Tabela 6 - Valores para classificação do risco de degradação dos locais de interesse geológico de acordo com Rocha et al. (2016).

\begin{tabular}{|c|c|}
\hline Valor final & Risco de degradação \\
\hline $0<=$ Valor $<=200$ & Baixo \\
\hline $200<$ Valor $<=300$ & Médio \\
\hline $300<$ Valor $<=400$ & Alto \\
\hline
\end{tabular}

Tabela 7 - Pesos atribuídos para avaliação quantitativa do potencial de uso educativo e turístico de acordo com Rocha et al. (2016).

\begin{tabular}{|c|c|c|c|}
\hline & Critério & Educativo & Turístico \\
\hline C1 & Vulnerabilidade & $10 \%$ & $10 \%$ \\
\hline C2 & Acessibilidade & $10 \%$ & $10 \%$ \\
\hline C3 & Limitações ao uso & $5 \%$ & $5 \%$ \\
\hline C4 & Segurança & $10 \%$ & $10 \%$ \\
\hline C5 & Logística & $5 \%$ & $5 \%$ \\
\hline C6 & Densidade populacional & $5 \%$ & $5 \%$ \\
\hline C7 & Associação com outros valores & $5 \%$ & $5 \%$ \\
\hline C8 & Beleza cênica & $5 \%$ & $15 \%$ \\
\hline
\end{tabular}

Continua. 
Continuação...

\begin{tabular}{|c|c|c|c|}
\hline & Critério & Educativo & Turístico \\
\hline C9 & Singularidade & $5 \%$ & $10 \%$ \\
\hline C10 & Condições de observação & $10 \%$ & $5 \%$ \\
\hline C11 & Potencial didático & $20 \%$ & - \\
\hline C12 & Diversidade geológica & $10 \%$ & - \\
\hline C13 & Potencial para divulgação & - & $10 \%$ \\
\hline C14 & Nível econômico & - & $5 \%$ \\
\hline C15 & Proximidade a zonas recreativas & - & $5 \%$ \\
\hline & Total & $100 \%$ & $100 \%$ \\
\hline
\end{tabular}

\subsection{Enquadramento Legal}

A identificação do enquadramento legal foi realizada através de consultas a sites dos órgãos gestores, como ICMBIO, Fundação Florestal, prefeituras, plano de manejo das unidades de conservação, mapas e cadernos de educação ambiental sobre unidades de conservação elaborados pela Secretaria de Estado do Meio Ambiente de São Paulo. 


\section{DESCRIÇÃO DOS LUGARES DE INTERESSE GEOLÓGICO}

\subsection{Introdução}

Este capítulo apresenta a descrição das principais características de cada local selecionado. No total foram definidos 12 geossítios, sete em Iguape e quatro na llha Comprida e um no limite entre os dois municípios, além de um sítio da geodiversidade, em Iguape (Fig.4).

Todos os sítios selecionados neste inventário estão em áreas protegidas, sendo que alguns locais pertencem a mais de uma unidade de conservação. Para efeitos de descrição da proteção legal serão indicadas neste trabalho as unidades que são responsáveis pela gestão de cada ponto.

A história geológica da região é representada pelos seguintes geossítios, distribuídos entre seis categorias geológicas (CG) definidas em Garcia et al. (2018) (Tabela 8 ):

1) CG Geomorfologia e evolução da paisagem: Morro do Espia e Maciço da Jureia;

2) CG Evolução quaternária: Cordões litorâneos e Paleodunas da praia da Jureia,Terraços holocênicos do Pontal da Trincheira, Dunas, paleodunas e paleolagunas da Ilha Comprida e Campo de dunas ativas do Araçá; Processos sedimentares da desembocadura do rio Ribeira de Iguape;

3) CG Magmatismo alcalino do Cretáceo Tardio: Intrusão alcalina da llha Comprida;

4) CG Zonas de cisalhamento: Granito Iguape com feições miloníticas;

5) CG Magmatismo granítico sin-tectônico: Granito Iguape no Morro do Espia;

6) CG Terreno Curitiba: Granulitos do Complexo Itatins na Cachoeira do Paraíso e Paragnaisses da Praia da Jureia.

Somente um sítio da geodiversidade foi inventariado: Paragnaisses da Cachoeira Grande. 
Tabela 8 - Geossítios e sítios da geodiversidade dos municípios de lguape e llha Comprida distribuídos segundo as categorias geológicas definidas em Garcia et al. (no prelo). Interesse geológico principal de acordo com Rocha et al. (2016) GEOSSIT. 'Sítio da geodiversidade

\begin{tabular}{|c|c|c|c|c|c|}
\hline $\begin{array}{l}\text { Categorias } \\
\text { Geológicas (CG) }\end{array}$ & Sítio & Município & $\begin{array}{l}\text { Interesse } \\
\text { geológico } \\
\text { principal }\end{array}$ & Tipologia & $\begin{array}{r}\text { Área de } \\
\text { Proteção } \\
\text { Ambienta }\end{array}$ \\
\hline \multirow{2}{*}{$\begin{array}{l}\text { Geomorfologia e } \\
\text { evolução da } \\
\text { paisagem }\end{array}$} & Maciço da Jureia & Iguape & Geomorfológico & Área & APACIP \\
\hline & Morro do Espia & Iguape & Geomorfológico & Área & APACIP \\
\hline \multirow{5}{*}{$\begin{array}{l}\text { Evolução } \\
\text { quaternária }\end{array}$} & $\begin{array}{c}\text { Cordões litorâneos e } \\
\text { paleodunas da praia da } \\
\text { Jureia }\end{array}$ & Iguape & Sedimentológico & Área & APACIP \\
\hline & $\begin{array}{l}\text { Terraços holocênicos do } \\
\text { Pontal da Trincheira }\end{array}$ & $\begin{array}{c}\text { Ilha } \\
\text { Comprida }\end{array}$ & Sedimentológico & Área & $\begin{array}{l}\text { APA llha } \\
\text { Comprida }\end{array}$ \\
\hline & $\begin{array}{l}\text { Dunas, paleodunas e } \\
\text { paleolagunas da llha } \\
\text { Comprida }\end{array}$ & $\begin{array}{l}\text { Ilha } \\
\text { Comprida }\end{array}$ & Sedimentológico & Área & $\begin{array}{l}\text { APA llha } \\
\text { Comprida }\end{array}$ \\
\hline & $\begin{array}{l}\text { Campo de dunas } \\
\text { ativas do Araçá }\end{array}$ & $\begin{array}{l}\text { Ilha } \\
\text { Comprida }\end{array}$ & Sedimentológico & Área & $\begin{array}{l}\text { APA llha } \\
\text { Comprida }\end{array}$ \\
\hline & $\begin{array}{l}\text { Processos sedimentares } \\
\text { da desembocadura do rio } \\
\text { Ribeira de Iguape }\end{array}$ & $\begin{array}{l}\text { Iguape/ llha } \\
\text { Comprida }\end{array}$ & Sedimentológico & Área & APACIP \\
\hline $\begin{array}{l}\text { Magmatismo } \\
\text { alcalino do } \\
\text { Cretáceo Tardio }\end{array}$ & $\begin{array}{c}\text { Intrusão alcalina da Ilha } \\
\text { Comprida }\end{array}$ & $\begin{array}{l}\text { Ilha } \\
\text { Comprida }\end{array}$ & Ígneo & Ponto & $\begin{array}{l}\text { APA llha } \\
\text { Comprida }\end{array}$ \\
\hline $\begin{array}{c}\text { Zonas de } \\
\text { cisalhamento }\end{array}$ & $\begin{array}{l}\text { Granito Iguape com } \\
\text { feições miloníticas }\end{array}$ & Iguape & Ígneo & Ponto & APACIP \\
\hline $\begin{array}{l}\text { Magmatismo } \\
\text { granítico sin- } \\
\text { tectônico }\end{array}$ & $\begin{array}{c}\text { Granito Iguape no Morro } \\
\text { do Espia }\end{array}$ & Iguape & Ígneo & Ponto & APACIP \\
\hline \multirow{3}{*}{ Terreno Curitiba } & $\begin{array}{c}\text { Granulitos do Complexo } \\
\text { Itatins na Cachoeira do } \\
\text { Paraíso }\end{array}$ & Iguape & Ígneo & Ponto & $\begin{array}{l}\text { Parque } \\
\text { Estadual } \\
\text { Itinguçu }\end{array}$ \\
\hline & $\begin{array}{l}\text { Paragnaisses da Praia } \\
\text { da Jureia }\end{array}$ & Iguape & Metamórfico & Ponto & APACIP \\
\hline & $\begin{array}{l}\text { Paragnaisses da } \\
\text { Cachoeira Grande }\end{array}$ & Iguape & $\begin{array}{l}\text { Metamórfico } \\
\text { Tectônico }\end{array}$ & Ponto & $\begin{array}{l}\text { Parque } \\
\text { Estadual } \\
\text { Itinguçu }\end{array}$ \\
\hline
\end{tabular}




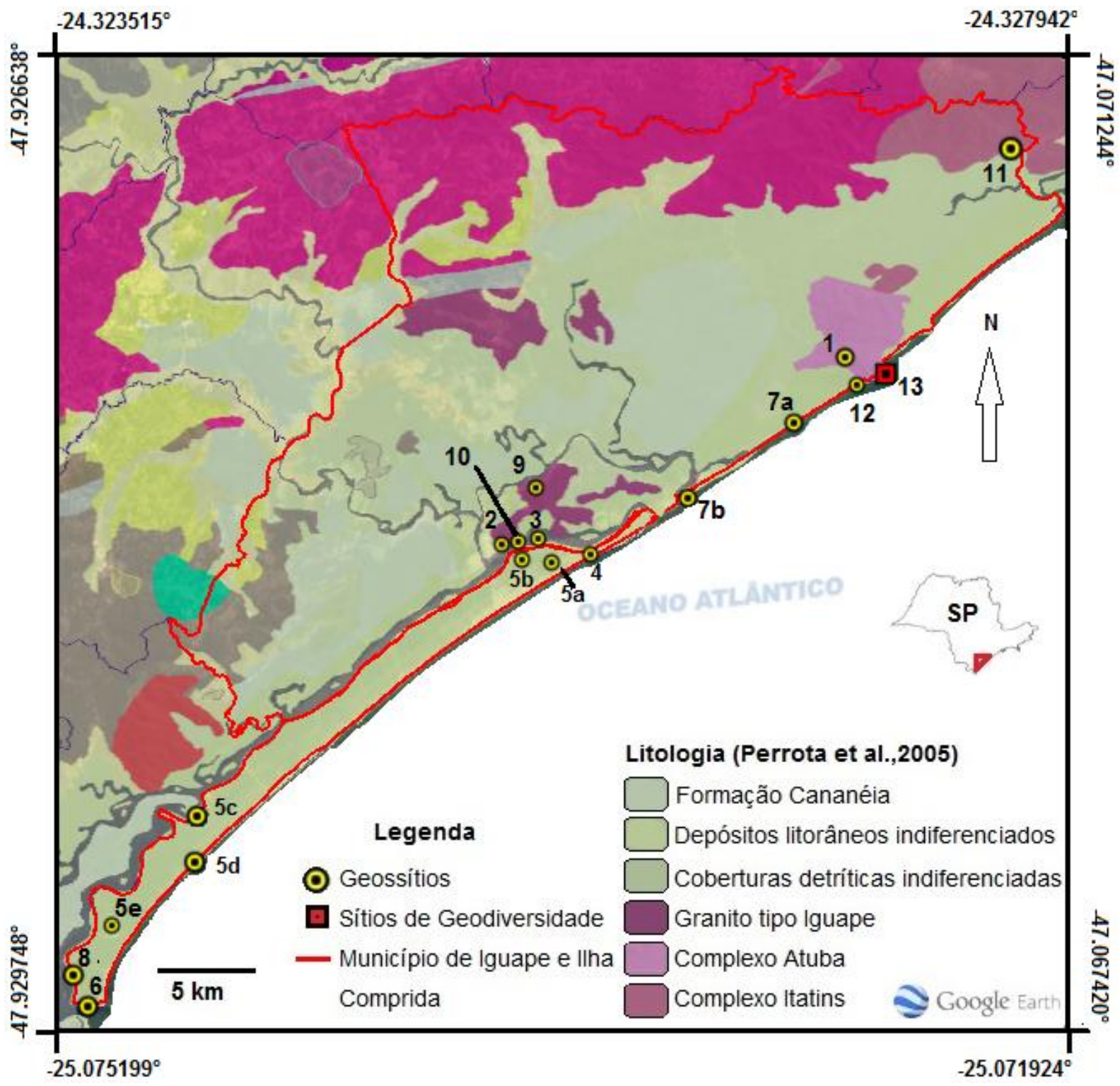

Figura 4 - Mapa de localização dos geossítios e sítios da geodiversidade. 1) Maciço da Jureia; 2) Morro do Espia; 3) Processos sedimentares da desembocadura do rio Ribeira de Iguape; 4) Campo de dunas ativas do Araçá; 5) Dunas, paleodunas e paleolagunas da llha Comprida a - Paleoduna em área urbanizada, b e c paleolagunas, $d$ - paleodunas com expressiva erosão, e- paleodunas densamente vegetadas; 6) Terraços holocênicos do Pontal da Trincheira; 7) Cordões litorâneos e paleodunas da praia da Jureia a - Paleodunas, b- dunas frontais e nebkas; 8) Intrusão alcalina da Ilha Comprida; 9) Granito Iguape com feições miloníticas; 10) Granito Iguape no Morro do Espia; 11) Granulitos do Complexo Itatins na Cachoeira do Paraíso; 12) Paragnaisses da Praia da Jureia; 13) Paragnaisses da Cachoeira Grande. 


\subsection{Descrição dos locais de interesse geológico}

\subsubsection{CG - Terreno Curitiba}

Geossítio "Granulitos do Complexo Itatins na Cachoeira do Paraíso"

Localização geográfica: -24.396193, -47.21948

Tipologia: Ponto

Proteção legal: Parque Estadual Itinguçu

Litotipo predominante: Rochas gnáissicas migmatíticas

Unidade (Perrota et al., 2005): Complexo Itatins (PP2ita)

A Cachoeira do Paraíso localiza-se no perímetro do município de Iguape, com acesso pelo município de Peruíbe. Do centro de Peruíbe percorrem-se $18 \mathrm{~km}$ pela Estrada do Guaraú-Una até a base do Núcleo Itinguçu, km 11, onde se encontra uma trilha de 250 metros que leva ao poço principal (Fig. 5A).

Localizado na Serra dos Itatins, o afloramento é bem heterogêneo e intensamente deformado. Predominam rochas gnáissicas de coloração cinza escuro a cinza claro, constituídos por bandas milimétricas a centimétricas félsicas de composição quartzo-feldspática, de granulação fina e bandas máficas de biotita e granada de granulação fina a média.

A foliação principal possui atitude média de $75^{\circ} / 20^{\circ} \mathrm{NW}$ e é plano axial a dobras intrafoliais (Fig. 5D). A tectônica extensional é evidenciada pelos boudins de rochas máficas que variam de 5 a $50 \mathrm{~cm}$ de comprimento (Fig. 4A; B). A foliação encontra-se intensamente dobrada (Fig. 5E). Ocorrem xenólitos com dimensões de 2 a $30 \mathrm{~cm}$, orientados ao longo da foliação, que apresentam formas irregulares, desde angulosas a dobradas (Fig. 5C).

Picanço (1994), em seu estudo sobre o Maciço Itatins obteve dados Rb-Sr que indicam que os protólitos dessas rochas possuem idades paleoproterozoicas e que foram provavelmente formadas em ambiente de convergência de placas, sendo posteriormente afetadas pelo Ciclo Brasiliano, no Neoproterozoico (720-580 Ma).

O geossítio pode ser utilizado para fins educativos voltados para alunos de ensino superior e técnico, pois os processos e feições geológicas podem ser facilmente observáveis como dobras, xenólitos, boudins e intrusões. O local também 
apresenta potencial turístico, visto que a cachoeira possui beleza cênica e recebe muitos turistas na alta temporada.

O local possui limitação de acesso na temporada, 200 pessoas por dia. Para acessar a cachoeira é necessário passar pela base do Núcleo Itinguçu, onde os visitantes são recebidos por monitores e recebem informações sobre segurança e sobre a unidade de conservação (Fig. 5 F;G). O acesso ao poço principal é feito por uma trilha bem demarcada, com infraestrutura como corrimões, placas indicativas e mapa de localização.

Vulnerabilidade natural: Baixa - não sujeita a eventos naturais Vulnerabilidade antrópica: Baixa - área com controle de acesso Fragilidade: Baixa - rochas resistentes 

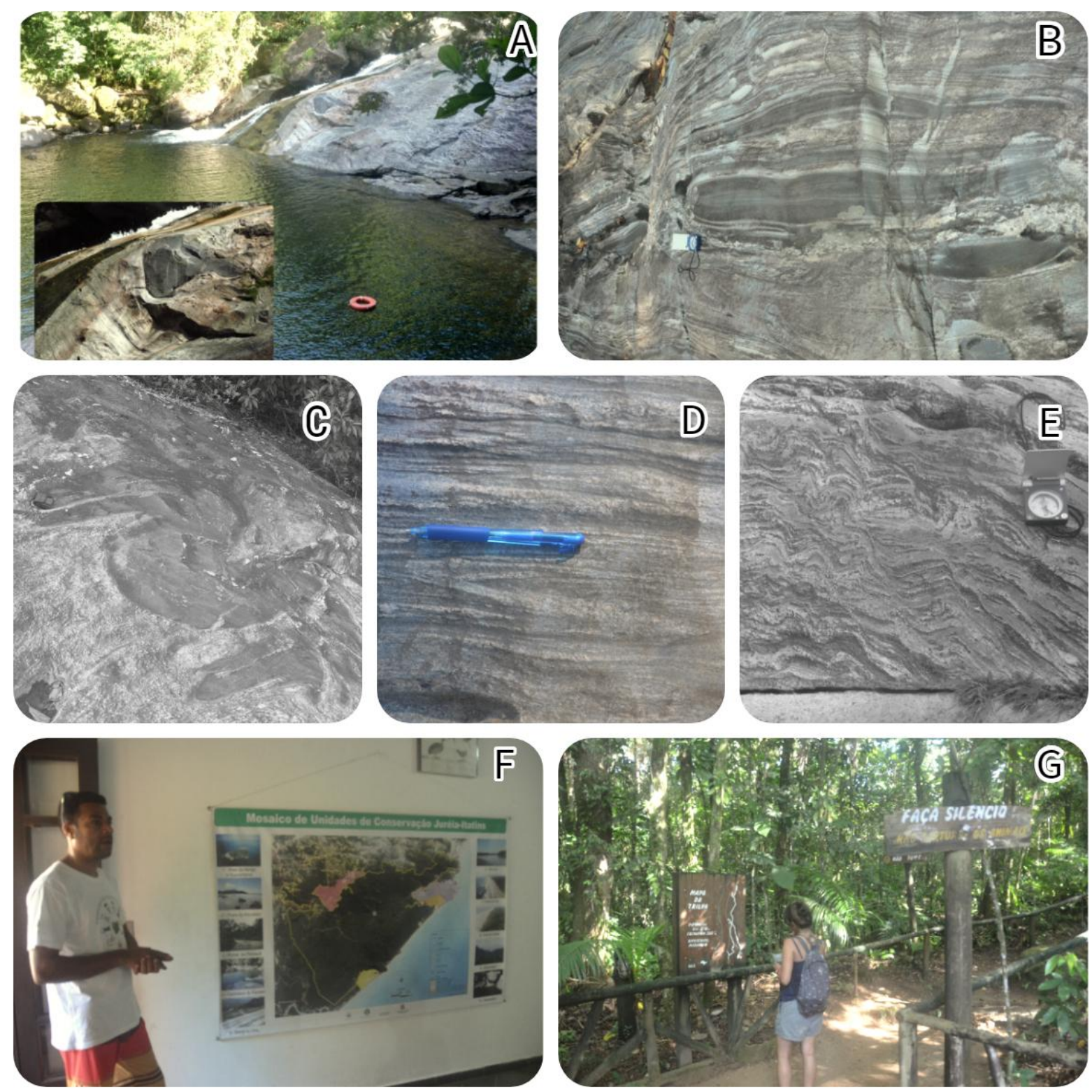

Figura 5 - Geossítio "Granulitos do Complexo Itatins na Cachoeira do Paraíso". A) Poço principal da cachoeira com destaque para xenólito de rocha máfica; B) Boudins de rocha máfica indicativos da tectônica extensional; C) Xenólito de rocha máfica deformado. Plano axial paralelo à foliação principal; D) Dobra intrafolial com plano axial paralelo à foliação da rocha; E) Foliação plano-axial intensamente dobrada em evento posterior; F) Recepção com informações sobre segurança e sobre a unidade de conservação; G) Infraestrutura do local com placas, mapa das trilhas, corrimões e escadas. 
Geossítio "Paragnaisses da Praia da Jureia"

Localização geográfica: -24.570978, -47.237323

Tipologia: Ponto

Proteção legal: Parque Estadual do Prelado

Litotipo predominante: Paragnaisses

Unidade Perrota et al. (2005): Complexo Atuba

O geossítio localiza-se na praia da Jureia no bairro do Ribeira, a $36 \mathrm{~km}$ do centro de lguape. $O$ acesso pode ser feito pela estrada do Icapara, ao final atravessa-se a balsa até o bairro da Ribeira. Na praia da Jureia percorre-se $15 \mathrm{~km}$ pela praia até o afloramento, localizado no costão rochoso, base do Maciço da Jureia (Fig 6 C).

O corpo rochoso é composto principalmente por muscovita-biotita gnaisse com estrutura bandada. Predomina bandamento composicional paralelo à foliação, bandas finas centimétricas a decimétricas de composição quartzo-feldspática intercaladas com porções mais xistosas, com lentes quartzosas sigmoidais com textura granoblástica (Fig.6 A), Ocorrem dobras suaves com planos axiais perpendiculares à foliação e boudins centimétricos de rochas máficas intercaladas no bandamento (Fig. 6 B).

Cury (2009) descreve as rochas do costão como pertencentes ao Complexo Turvo-Cajati, do Terreno Paranaguá. Passarelli (2001) classifica estas rochas como pertencentes ao bloco Registro da porção centro-sul do estado de São Paulo, limitado entre as zonas de cisalhamento Cubatão-Itariri e Serrinha. Segundo a autora, as rochas apresentam-se intensamente afetadas pelo Ciclo Brasiliano, em fácies anfibolito alto, com idades U-Pb em monazitas de $750 \mathrm{Ma}$.

Além do seu valor científico, o geossítio apresenta alto potencial turístico, visto que a praia já recebe muitos turistas durante o ano. Além disso, o local é passagem para uma conhecida trilha ecoturística, a Trilha do Imperador.

O local possui potencial educativo voltado para alunos de ensino superior e técnico, uma vez que as feições geológicas desse afloramento são facilmente observáveis e as feições geomorfológicas também são de fácil visualização, inclusive por imagens de satélites. 
Vulnerabilidade natural: Baixa

Vulnerabilidade antrópica: Baixa - praia com acesso livre, inclusive para veículos Fragilidade: Baixa/média - alterações intempéricas
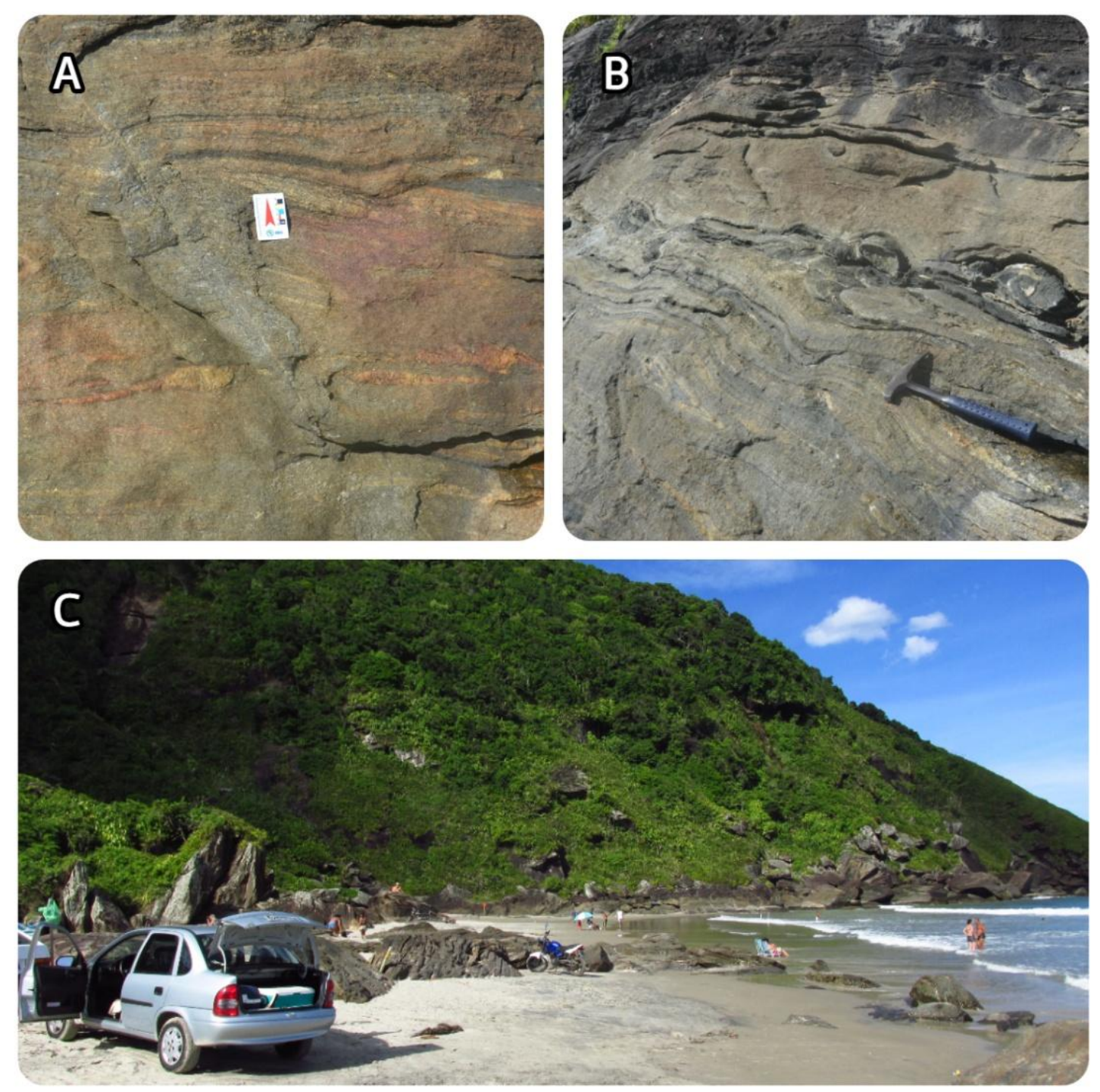

Figura 6 - Geossítio "Paragnaisses da Praia da Jureia". A) Aspecto bandado da rocha, com intercalações de níveis félsicos e máficos. Destaque para as lentes quartzosas sigmoidais; B) Boudins centimétricos de rochas máficas intercalados no bandamento;C) Vista geral do afloramento, onde observa-se carros e motos próximos ao geossítio. 


\subsubsection{CG - Magmatismo granítico sin-tectônico}

\section{Geossítio "Granito Iguape no Morro do Espia"}

Localização geográfica: -24.693111, -47.535735

Tipologia: Ponto

Proteção legal: APA Cananeia, Iguape e Peruíbe

Litotipo predominante: Sieno graníticas porfirítica

Unidade Perrota et al. (2005): Unidades graníticas

O geossítio está localizado na base do Morro do Espia e o acesso é pela antiga estrada do Icapara, em Iguape. Encontra-se numa propriedade particular, um restaurante que serve como local de lazer e turismo. Existem dois afloramentos principais, ambos formados por rochas sieno graníticas levemente alteradas, com coloração bege esbranquiçada. Essas rochas são denominadas, segundo Passarelli (1991), como granito tipo Iguape.

O primeiro afloramento possui estrutura foliada (fenocristais euédricos orientados segundo $\mathrm{N} 10$, textura inequigranular porfirítica com fenocristais de 1 a 2 $\mathrm{cm}$ de feldspato alcalino tabular e matriz fina a média composta por quartzo, plagioclásio, feldspato potássico e biotita (Fig. 7A). Ocorrem enclaves centimétricos $(<20 \mathrm{~cm})$ de cor cinza escuro e granulação fina. Observa-se um dique pegmatítico de 30 a $40 \mathrm{~cm}$ de espessura orientado segundo a direção N40 com estrutura maciça e minerais máficos orientados perpendicularmente à borda do dique. A textura é inequigranular grossa e a rocha é composta por quartzo, feldspato potássico, plagioclásio e minerais máficos boudinados (turmalina) (Fig. 7B). Datações U-Pb feitas por Passarelli (2001) indicam idades de $600 \mathrm{Ma}$, interpretadas como a época de cristalização da rocha.

Em outro ponto dessa propriedade há um pequeno lago artificial com afloramento da mesma rocha, com ocorrência de xenólitos de rocha máfica que variam de 10 a $30 \mathrm{~cm}$ (Fig. 7C). O afloramento possui algumas alterações antrópicas devido à formação do lago artificial.

O geossítio possui grande potencial turístico por estar localizado em um ambiente de lazer para os visitantes. No local há também ruínas de antigas construções feitas por escravos, utilizando argila, conchas e óleo de baleia, que 
valorizam a parte histórica e cultural do sitio (Fig. 7D). Possui potencial educativo para alunos de ensino superior e técnico.

Vulnerabilidade natural: Baixa

Vulnerabilidade antrópica: Baixa/média - propriedade privada, mas com possibilidade de modificações

Fragilidade: Baixa
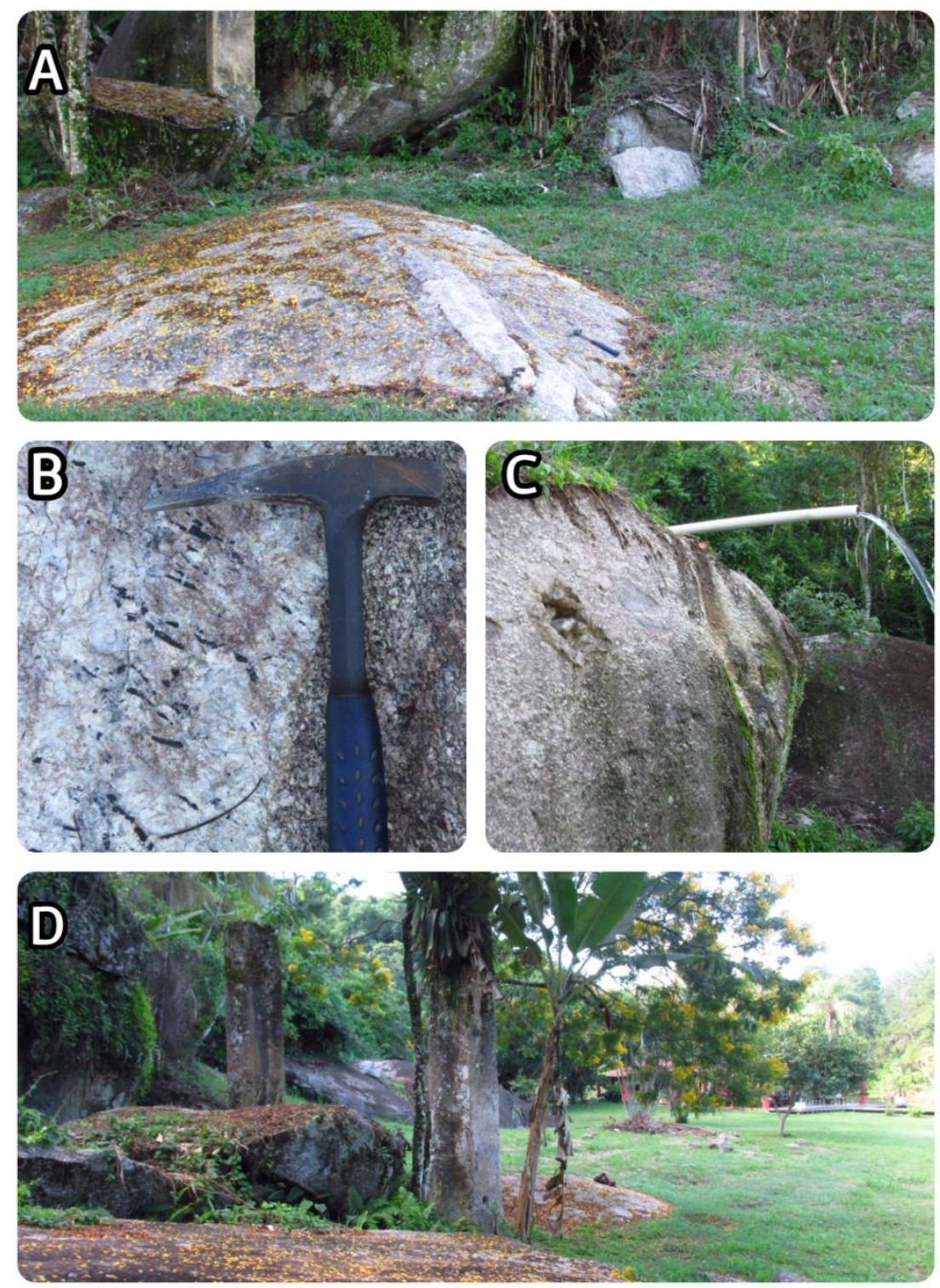

Figura 7 - Geossítio "Granito Iguape no Morro do Espia”._A) Vista do primeiro afloramento, com destaque para o dique pegmatítico; B) Detalhe do dique com turmalinas orientadas e boudinadas; C) Vista do segundo afloramento, onde 
observam-se xenólitos de rocha máfica; D) Ruínas de antigas construções feitas por escravos, utilizando argila, conchas e óleo de baleia.

\subsubsection{CG - Zonas de cisalhamento}

\section{Geossítio "Granito lguape com feições miloníticas"}

Localização geográfica: -24.656156, -47.519935

Tipologia: Ponto

Proteção legal: APA - Cananeia, Iguape e Peruíbe

Litotipo predominante: Granito milonítico porfirítico

Unidade Perrota et al. (2005): Unidades graníticas

O geossítio localiza-se no município de Iguape, na beira da Rodovia Prof. Casemiro Teixeira (SP-222), aproximadamente no no 6.400. Encontra-se no quintal de uma residência (Fig. $8 \mathrm{C}$ )

A rocha encontra-se moderadamente alterada e possui coloração clara, de esbranquiçada a cinza. Sua estrutura é foliada anastomosada, definida pelo estiramento dos minerais da matriz inequigranular. A textura é protomilonítica e os minerais essenciais são feldspato potássico, quartzo e plagioclásio. Biotita, granada e muscovita ocorrem como fases acessórias (Fig. 8A).

Segundo Cury (2009), o geossítio pertence ao Terreno Paranaguá, constituído em grande parte por um complexo ígneo. Esse complexo é representado pela Suite Morro Inglês, que apresenta rochas graníticas típicas de arco magmático. As estruturas observadas nesse terreno sugerem relação com uma tectônica de nappes de direção nor-nordeste, que provavelmente está inserida no contexto da aglutinação da porção oeste do Supercontinente Gondwana (Cury, 2009).

O geossitio não possui potencial educativo, pois suas feições principais encontram-se alteradas e de difícil observação. Também não possui beleza cênica e está localizado em uma propriedade particular, portanto não possui potencial turístico.

\section{Vulnerabilidade natural: Baixa}


Vulnerabilidade antrópica: Moderada - lixo e entulho são encontrados em parte do afloramento (Fig. 8B)

Fragilidade: Moderada - intemperismo intenso
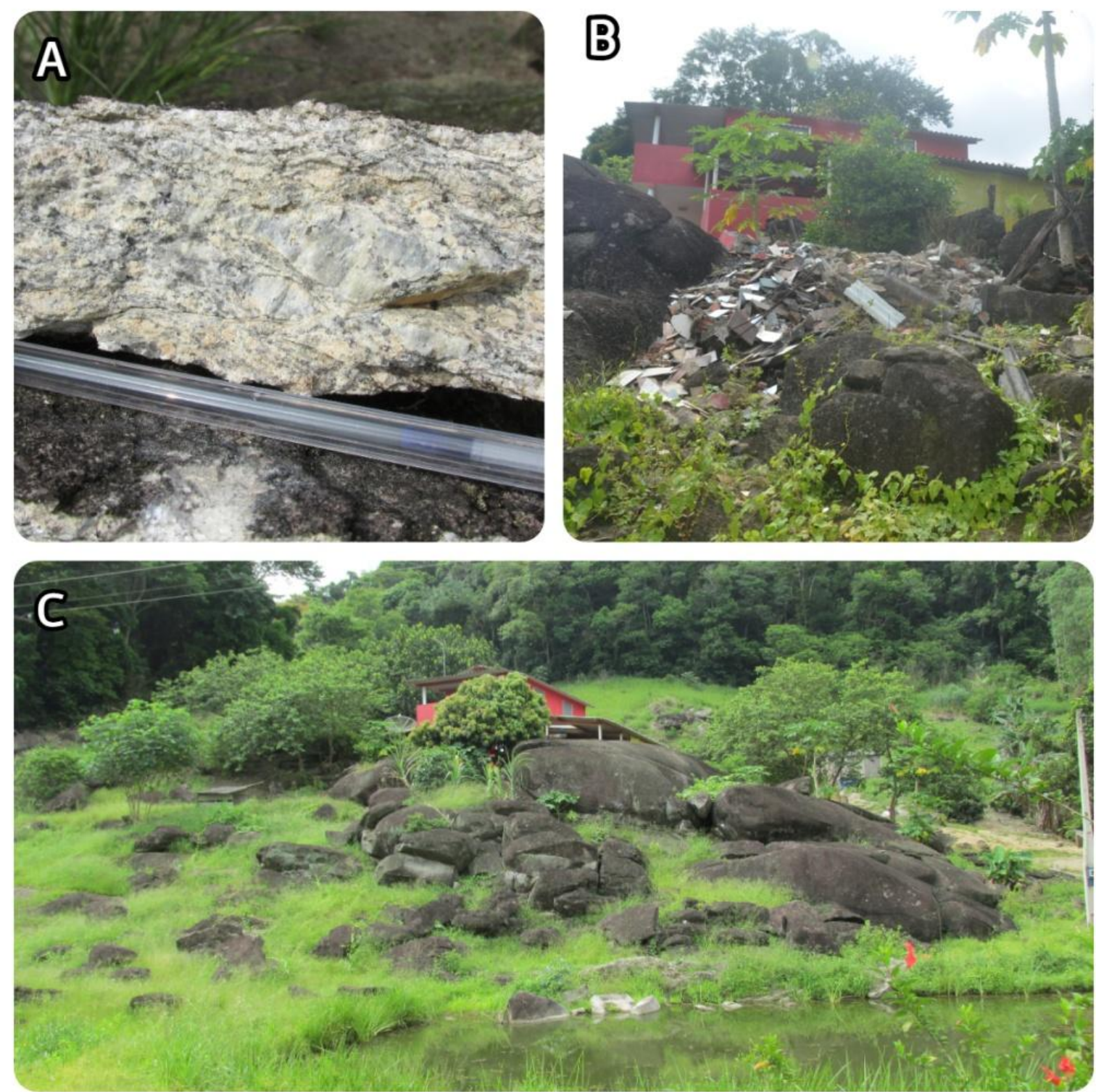

Figura 8 - Geossítio "Granito Iguape com feições miloníticas._A) Detalhe do Granito moderadamente alterado; B) Entulho e lixo jogados entre a rocha; C) Vista geral do geossítio. 


\subsubsection{CG - Magmatismo alcalino do Cretáceo Tardio}

Geossítio "Intrusão alcalina de Ilha Comprida"

Localização geográfica: -25,089115, -47,912757

Tipologia: Ponto

Proteção legal: APA Ilha Comprida

Litotipo predominante: Sieno granito

Unidade Perrota et al. (2005): Coberturas Cenozoicas

O geossítio encontra-se próximo ao boqueirão sul do município de llha Comprida. De Cananeia a travessia é feita por balsa e, em seguida, pega-se a estrada de terra sentido orla e, a cerca de $600 \mathrm{~m}$ adiante, toma-se a primeira via à direita, que passa ao lado do geossítio.

O corpo intrusivo, denominado na bibliografia por Morrete, é um satélite do stock alcalino Morro de São João, localizado em Cananeia (Fig. 10C). O afloramento tem dimensões de $470 \mathrm{~m} \times 47 \mathrm{~m}$ e encontra-se fortemente intemperizado. $\mathrm{O}$ acesso é dificultado pela densa vegetação, sendo possível apenas observar blocos de 0,5 a 1 metro. É constituído por rochas sieníticas leucocráticas, com estrutura maciça e coloração entre tons de cinza claro e escuro. A rocha é constituída predominantemente por feldspato alcalino grosso, com quartzo subordinado. A granulação varia de média a grossa, com textura inequigranular, ocasionalmente porfirítica, com cristais de feldspato alcalino em meio a uma matriz fina (Fig. 10A). Os minerais máficos são anfibólio, clinopiroxênio, biotita, óxidos e magnetita. Idades $\mathrm{Rb}-\mathrm{Sr}$ indicam cerca de 83,5 Ma para a cristalização da rocha (Spinelli e Gomes, 2008).

As intrusões alcalinas Morro de São João e Morrete foram estudadas por Suguio et al. (1987, apud Spinelli, 2007) que, através de perfilagens geofísicas, constataram a existência de uma laje denominada "Laje do Argolão", mais tarde estudadas por Spinelli (2007), que sugere uma sequência cronológica de formação para a essas intrusões alcalinas, representadas na Fig. 9. 

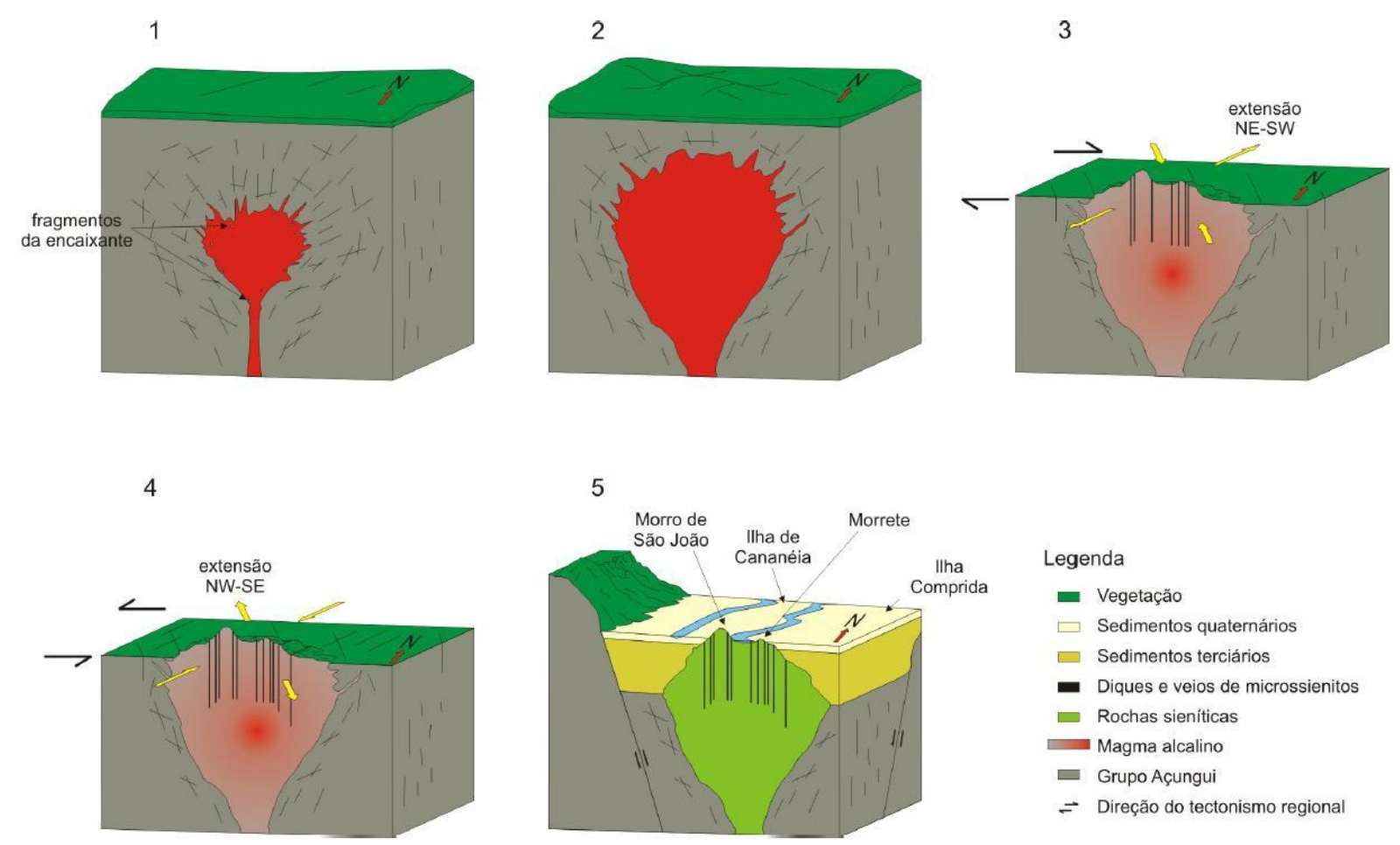

Figura 9 - Sequência de formação do geossítio Intrusão alcalina da llha Comprida. 1 e 2 - Intrusão do magma alcalino nas rochas encaixantes do Grupo Açungui; 3 - desenvolvimento da superfície do Japi no Senoniano com extensão NE-SW e intrusão de diques NW-SE; 4 - avanço da erosão na Superfície do Japi no Paleozóico/Eoceno NW-SE e intrusão de diques NE/SW; 5 - recuo erosivo da Serra do Mar e formação da Planície Costeira Cananéia-Iguape (Spinelli, 20017).

O geossítio se destaca pelo seu valor científico, pois o estudo dessas rochas ígneas sieníticas colaboram para a compreensão da dinâmica extensional da região, visto que essa intrusão alcalina está associada ao lineamento Guapiara, reativado durante a consolidação das margens passivas do oceano Atlântico Sul (Spinelli, 2007). É importante ressaltar a ocorrência global de diversos minerais raros em corpos ígneos alcalinos, em especial os sieníticos.

O local não possui potencial turístico e/ou educativo, pois as feições geológicas estão muito alteradas, além de estar localizado numa propriedade particular que não possui atrativos turísticos.

Vulnerabilidade natural: Moderada

Vulnerabilidade antrópica: Baixa

Fragilidade: Moderada - intemperismo avançado, densa vegetação (Fig. 10B). 

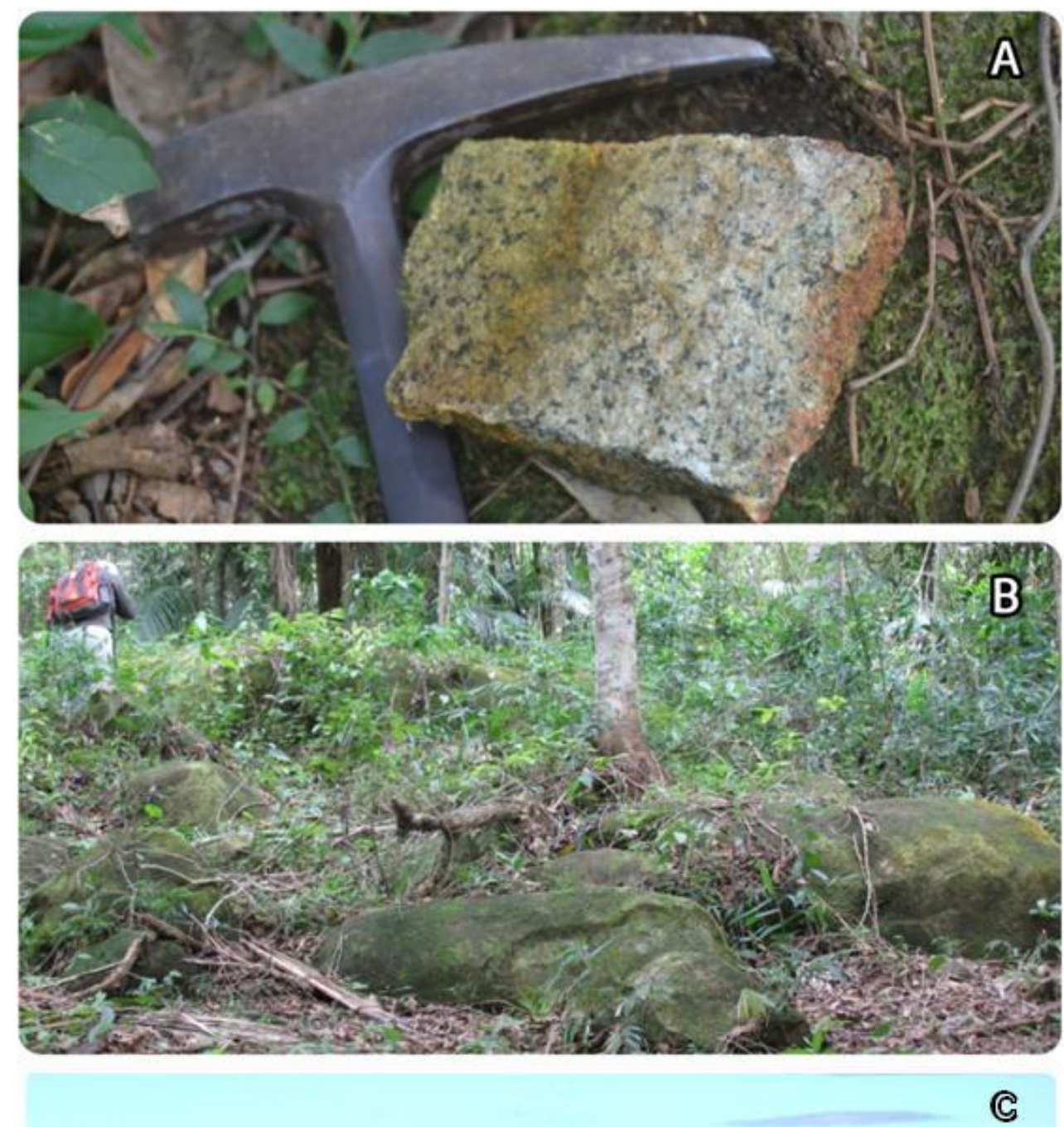

Morro São João

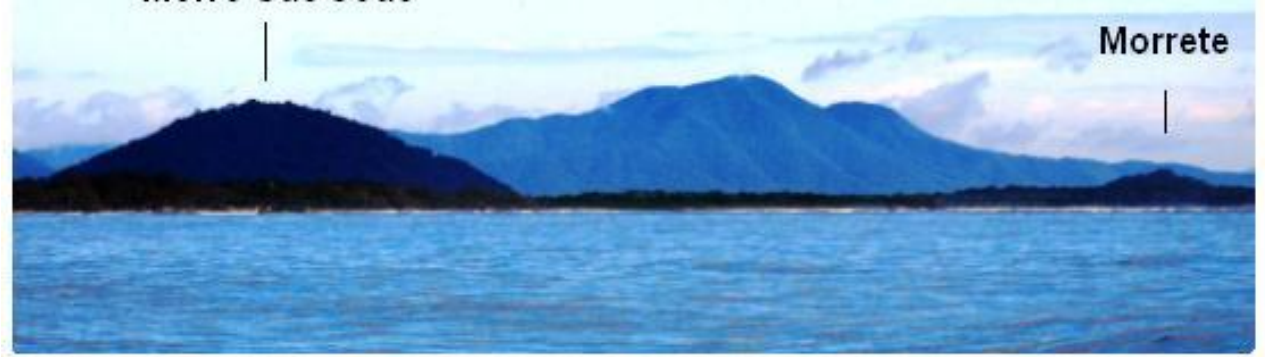

Figura 10- Geossítio "Intrusão alcalina da llha Comprida"._A) Detalhe do sieno granito que compõe os blocos; B) Vista geral do afloramento coberto por densa vegetação. 


\subsubsection{CG - Evolução quaternária}

Geossítio "Cordões Litorâneos e Paleodunas da praia da Jureia"

Localização geográfica: $-24.712133,-47.4976851$

Tipologia: Área

Proteção legal: APA llha Comprida

Litotipo predominante: Sedimentos arenosos quaternários

Unidade Perrota et al. (2005): Coberturas Cenozoicas

O acesso ao geossítio é feito, a partir do centro do município de Iguape, seguindo sentido bairro do Icapara, com a balsa para a praia da Jureia. O geossítio localiza-se ao longo da praia, por $18 \mathrm{~km}$, em forma de cordões litorâneos e paleodunas alinhados paralelamente. Esses cordões são formados por dunas frontais, compostas por areia fina.

A praia da Jureia encontra-se em processo de erosão, sendo que as dunas frontais mais recentes foram removidas (fig. 11A). Na parte central da atual linha de costa é possível observar os depósitos de paleodunas, caracterizados por dunas altas, com cerca de 8 metros de altura e cobertas por densa vegetação, que as torna estabilizadas (Fig. 11B). As paleodunas possuem idades holocênicas, o que sugere que após a máxima transgressão do NRM (nível relativo do mar) houve progradação da linha de costa atual (Bentz, 2004). Algumas casas na beira da praia foram construídas em meio aos cordões litorâneos e, à medida que a praia erode, os moradores vão criando contenções para segurar a erosão, modificando as estruturas das dunas (Fig.11C).

Esse geossítio possui valor turístico por ser localizado numa praia que já recebe muitos turistas na alta temporada. Possui potencial educativo voltado para ensino superior.

Vulnerabilidade natural: Alta - região com erosão costeira Vulnerabilidade antrópica: Alta - sem controle de acesso; pode ser acessado por veículos

Fragilidade: Alta - sedimentos frágeis 

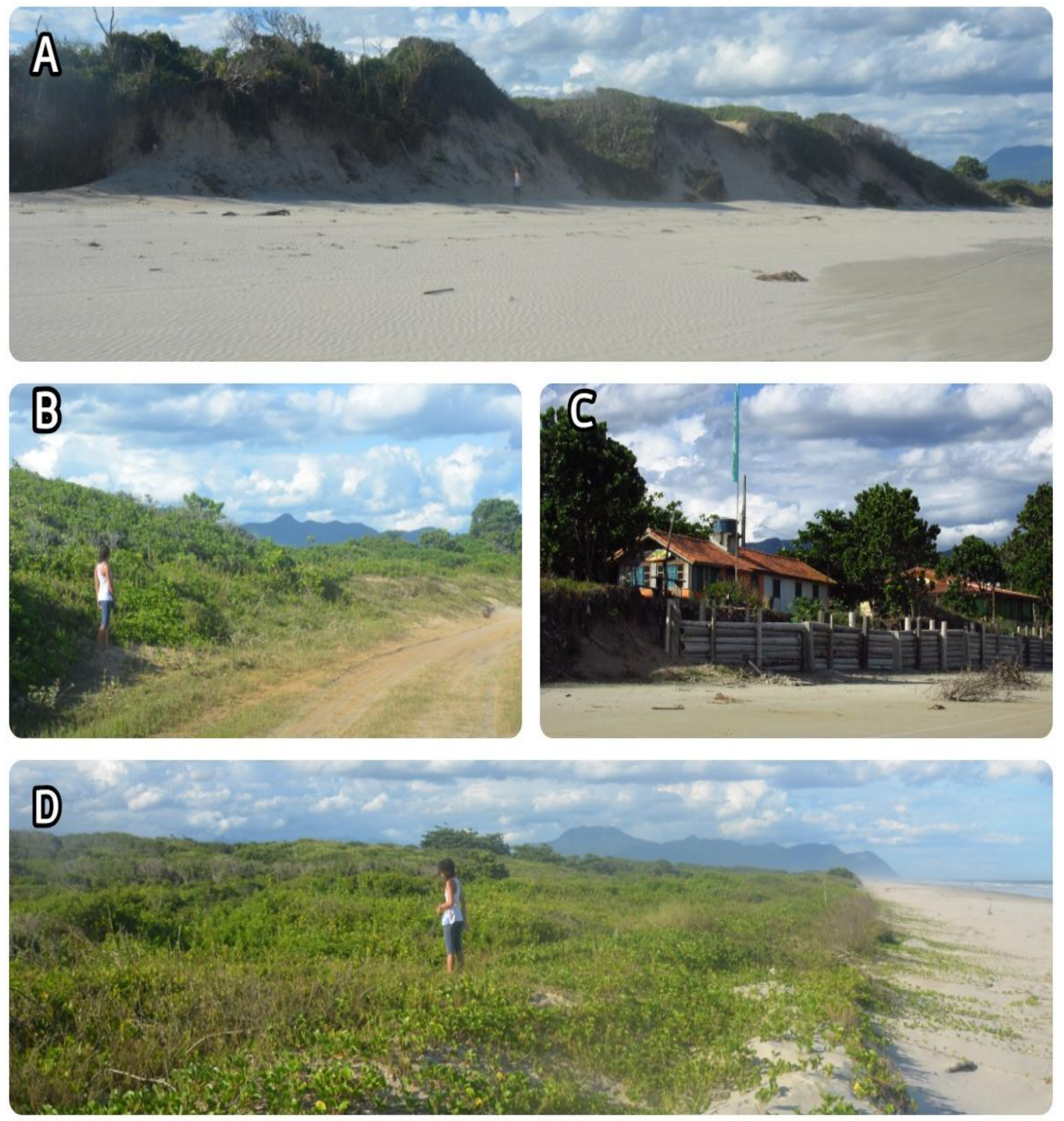

Figura 11 - Geossítio "Cordões Litorâneos e Paleodunas da praia da Jureia”._A) Paleodunas na linha da costa em processo de erosão; B) Paleodunas mais interiores cobertas por densa vegetação; C) Residências na beira da praia fazem contenção contra as fortes marés; D) Pequeno campo de nebkas; ao fundo o observa-se o maciço da Jureia. 


\section{Geossítio "Terraços holocênicos do Pontal da Trincheira"}

Localização geográfica: -25,3047, $-47,5403$

Tipologia: Área

Proteção legal: APA Ilha Comprida e Zona de Vida Silvestre

Litotipo predominante: Sedimentos arenosos quaternários

Unidade Perrotta et al. (2005): Coberturas Cenozoicas

O Pontal da Trincheira localiza-se no extremo sudoeste da llha Comprida. São terraços constituídos por fácies deposicionais que atingem cotas de 3 metros acima do nível médio do mar atual. O geossítio é composto por areias finas holocênicas com estratificação plano-paralela, no topo, e estratificação planoparalela com icnofóssies, na base (Guedes, 2009) (Fig.12A;C). Os icnofósseis ocorrem como tubos de cerca de $5 \mathrm{~cm}$ de diâmetro, característicos do artrópodo Callichirus major, pequenos invertebrados que viviam em águas rasas e que são indicativos das mudanças no NRM (Fig. 12B) (Guedes, 2009).

Os terraços correspondem à área mais antiga da ilha, datada por volta dos 6000 anos A.P. e que coincide com período de provável subida do NRM (Guedes, 2009), evidenciada por empilhamentos estratigráficos transgressivos.

Segundo Tessler et al. (1990), a erosão na Ponta da Trincheira se deve ao fato das águas nos canais lagunares ficarem retidas durante eventos climáticos e, consequentemente, na maré vazante, podem provocar o rompimento desta extremidade. Os mesmos autores ressaltam que os processos erosivos relacionamse à predominância das correntes de maré vazante que agem na Barra de Cananeia. Entre 1976 e 2011 Souza (2014) afirma que o Pontal da Trincheira recuou mais de 100 metros.

Essa área tem importância histórica por ter sido base para o Forte de Cananeia ou Forte da Trincheira, construído em 1824 e reedificado em 1839, porém hoje se encontra totalmente destruído (Mucivuna et al., 2016).

O local possui valor educativo voltado para alunos de ensino superior e técnico, pois as fácies deposicionais e icnofósseis são bem observáveis. Possui potencial turístico, visto que já é frequentado por turistas, principalmente na alta temporada, porém, é de difícil acesso, pois por ficar no extremo SW da ilha possui grande variação de maré e fortes ressacas em alguns períodos do ano, o que 
ocasiona em derrubada de árvores (Fig. 12E). Em alguns pontos é possível observar deterioração feita pelos turistas (Fig. 12D).

Vulnerabilidade natural: Alta - erosão avançada

Vulnerabilidade antrópica: Alta - sem limitação de acesso

Fragilidade: Alta
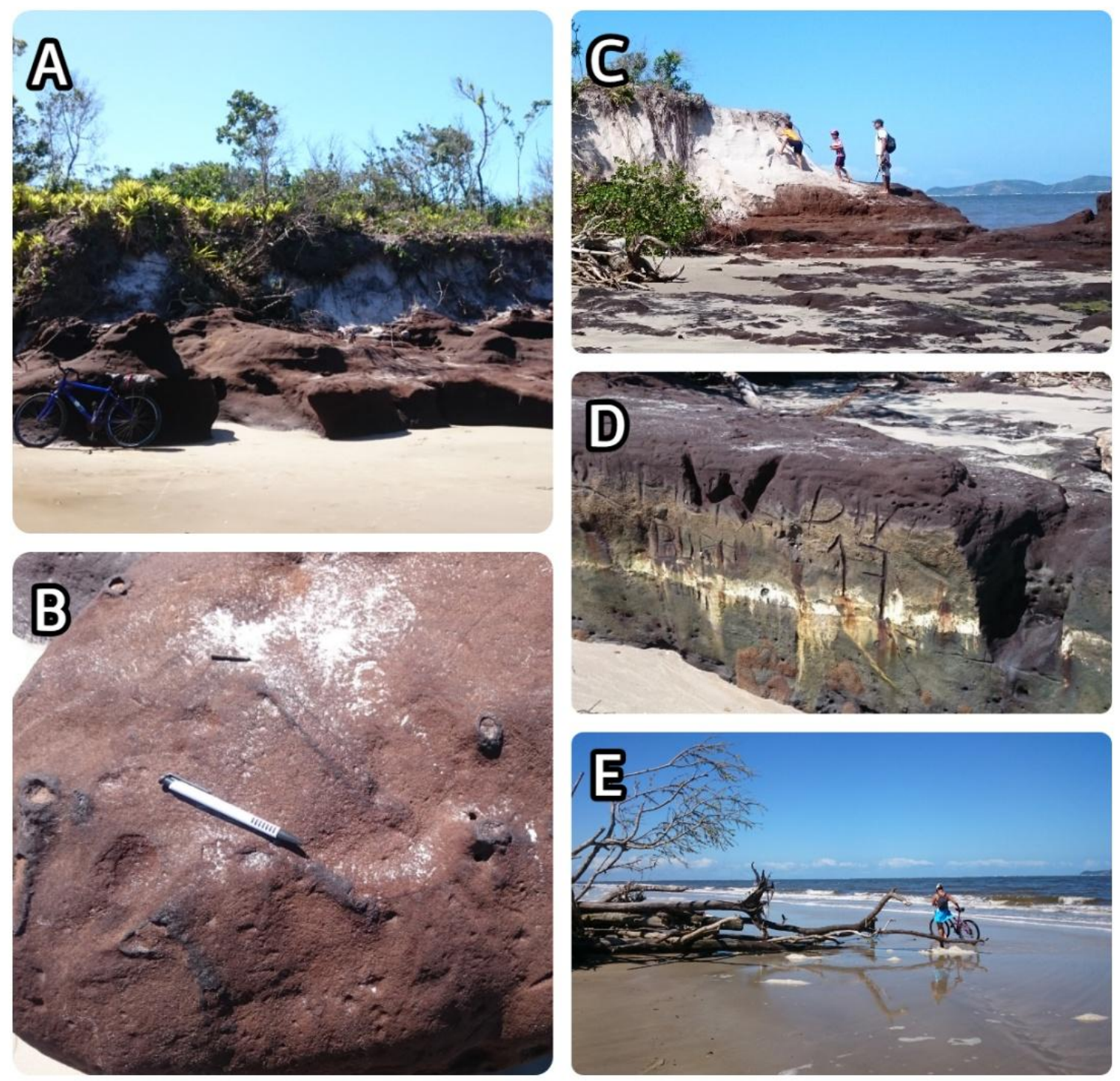

Figura 12 - Geossítio "Terraços holocênicos do Pontal da Trincheira"._A) Vista do afloramento, formado por areias finas holocênicas com estratificação plano-paralela, no topo, e estratificação plano-paralela com icnofóssies, na base; B) Vestígios do icnofóssil Callichirus Major; C) Turistas sobre o afloramento; D) Vandalismo observado em algumas porções do afloramento; E) Árvores derrubadas devido a intensas ressacas que resultam em alta erosão dos terraços. 
Geossítio "Dunas, paleodunas e paleolagunas da llha Comprida"

Localização geográfica: $-24.937047,-47.803179$

Tipologia: Área

Proteção legal: APA Ilha Comprida

Litotipo predominante: Sedimentos arenosos quaternários

Unidade Perrotta et al. (2005): Coberturas Cenozoicas

O geossítio é formado por alinhamentos de cordões litorâneos paralelos de dunas frontais, paleodunas e paleolagunas com diferentes características e que se estendem ao longo de toda a ilha, por cerca de $70 \mathrm{~km}$.

Segundo Guedes (2003), esses cordões litorâneos podem indicar a evolução espacial e temporal da ilha através de dois fatores. O primeiro seria que os alinhamentos mais interiores da ilha (paleolagunas e paleodunas), são mais antigos que os localizados próximos à costa atual (dunas eólicas e dunas frontais). $O$ segundo sugere que os cordões truncados são mais antigos do que os que truncam, representando a distinção nas etapas de crescimento da ilha.

Depósitos lagunares - Constituem os alinhamentos mais interiores e representam antigos fundos lagunares que se encontram emersos, ocasionalmente com inundações causadas pela maré. Essas áreas inundadas correspondem a antigos bancos de areia submersos, hoje ocupados por manguezais (Fig.13 E;F) (Guedes, 2009).

Cordões de paleodunas - Ocorrem até 1000 metros distante da praia atual e vão gradualmente se aproximando da praia rumo $S W$ até o $\mathrm{km} \mathrm{13}$, onde atualmente sofrem erosão causada principalmente pelas fortes marés e pelo turismo (Fig. 13A). Essa erosão causa a retirada da vegetação, formando falésias e rupturas de deflação (blowouts) causando a reativação dessas dunas (Fig. 13B;C). As idades obtidas superam 5.100 anos A.P. e permitem interpretar que a ilha é, em quase sua totalidade, mais antiga que o máximo NRM holocênico (Giannini et al. 2009; Guedes, 2011).

Cordões de dunas frontais - Localizam-se na parte mais externa, acompanhando a beira mar. Ocorrem diferentes feições eólicas, tais como dunas frontais ativas, nebkas e rupturas de deflação, algumas com até $12 \mathrm{~m}$ de altitude (Giannini et al. 2009). As dunas e os cordões litorâneos ao longo da praia foram 
utilizados para estudos sobre a evolução geológica da ilha (Suguio e Martin, 1978; Guedes 2009) e para denominar a unidade litoestratigráfica Ilha Comprida (Suguio e Martin, 1994).

Diversos estudos foram e estão sendo realizados sobre os alinhamentos dunares. O geossítio possui grande potencial educativo, pois além de existirem diversos tipos de dunas, estas encontram-se bem conservadas e são de fácil observação, constituindo-se nos melhores exemplos do estado. O geossítio possui potencial turístico, pois além da beleza cênica, suas formas chamam a atenção para o turismo de aventura, que é praticado principalmente na alta temporada (Fig. 11D;E).

Essas feições eólicas são extremamente frágeis e sua manutenção é imprescindível para a Ilha Comprida. Apesar de estar numa área de proteção ambiental, não há limitação de acesso, é permitida a circulação de veículos e até o ônibus municipal da cidade tem sua rota pela praia (Fig. 11B).

Vulnerabilidade natural: Alta - erosão

Vulnerabilidade antrópica: Alta - retirada da vegetação, circulação de veículos Fragilidade: Alta 

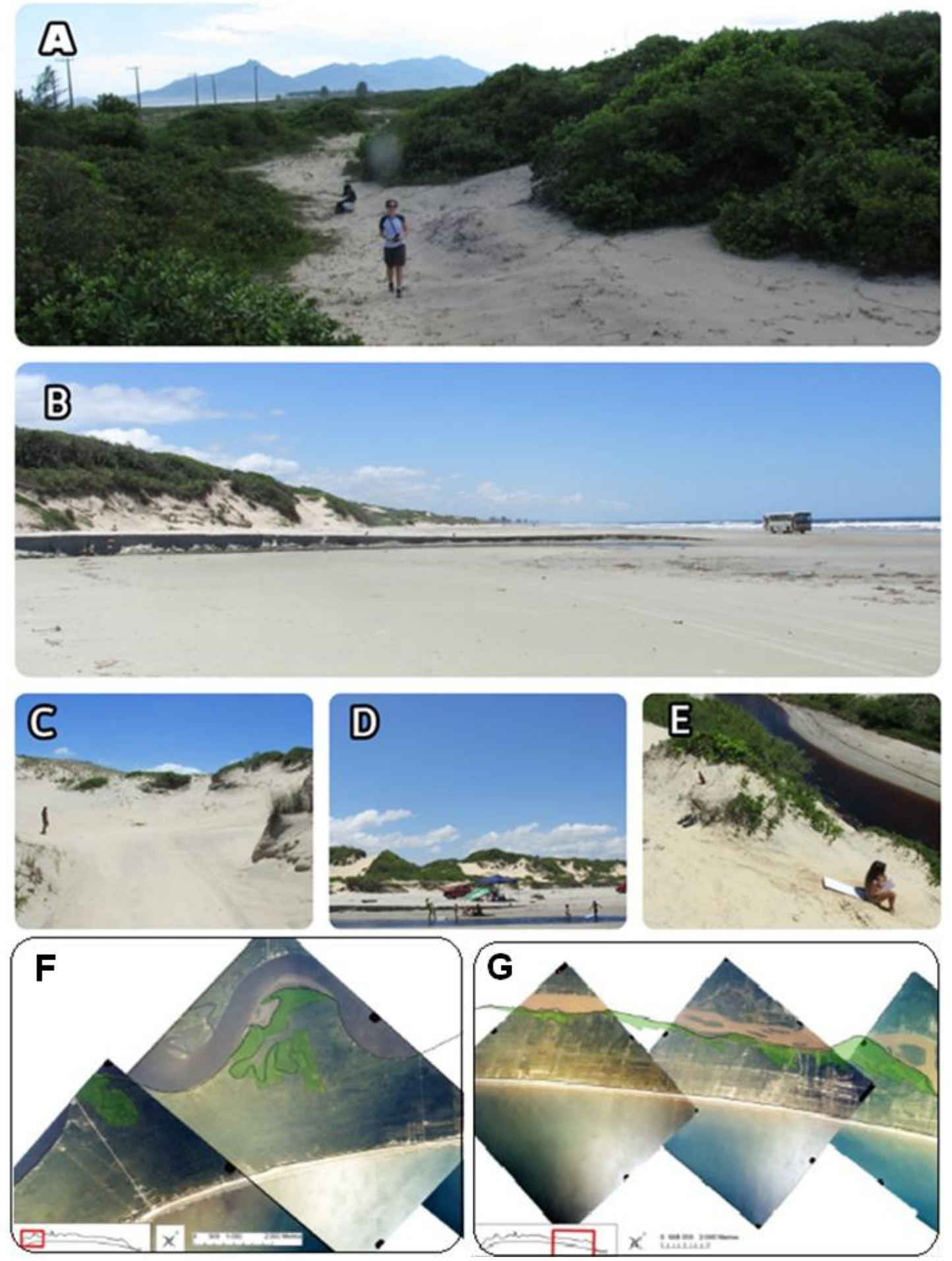

Figura 13 - Geossítio "Dunas, paleodunas e paleolagunas da llha Comprida".A) Cordões de paleodunas intensamente vegetadas; B) Paleodunas mais próximas da linha da costa, onde é possível observar a retirada da vegetação; C) Rupturas de deflação (blowout) causadas pela reativação das paleodunas; D) Turismo na ilha onde é permitido o acesso por veículos; E) Turistas escorregando sobre as dunas, atividade que ajuda na retirada da vegetação. E) Paleolagunas na porção Sul da Ilha F) Paleolagunas na região norte da ilha. E e F modificado Guedes (2009). 
Geossítio "Campo de dunas ativas do Aracá"

Localização geográfica: $-24.704888,-47.470733$

Tipologia: Área

Proteção legal: APA Ilha Comprida

Litotipo predominante: Sedimentos arenosos quaternários

Unidade Perrota et al. (2005): Coberturas Cenozoicas

Este geossítio está localizado na parte nordeste da ilha, onde se concentram as mudanças morfológicas mais significativas. Trata-se de um campo de dunas ativas com $2 \mathrm{~km}$ de extensão ao longo da costa e $400 \mathrm{~m}$ de largura, na região de máximo estreitamento (Fig. 14A). As dunas correspondem a depósitos de areia eólica de grande escala, onde se observam dunas parabólicas e barcanas com pouca vegetação, o que índica atividade com mobilidade para NW (Guedes, 2009; Giannini et al. 2009)( Fig. 14B;C).

Segundo Nascimento (2006), o crescimento da ilha através da deriva litorânea longitudinal teria sido bloqueada quando alcançou a região do Morro do Espia, tornando a região do campo de dunas a sua extremidade no período em que o Valo Grande foi aberto. Após a abertura, esse bloqueio começou a ser superado e a formação desse campo marca o período de "engorda", durante o qual a largura da ilha aumenta e o crescimento longitudinal se intensifica.

Nesta região onde a ilha teve seu recente crescimento longitudinal nos últimos 150 anos, houve intensa ocupação urbana, que anos mais tarde viria trazer grandes desastres por conta das fortes ressacas, causando erosão na praia e destruição de diversas casas ali presentes (Nascimento, 2006).

Esse geossítio possui grande beleza cênica, o que o torna um dos atrativos mais visitados da ilha. Seu relevo atrai muitos turistas durante o ano portanto, possui grande potencial turístico.

Vulnerabilidade natural: Alta - areias finas e em atividade

Vulnerabilidade antrópica: Alta - trânsito de veículos frequente

Fragilidade: Alta 

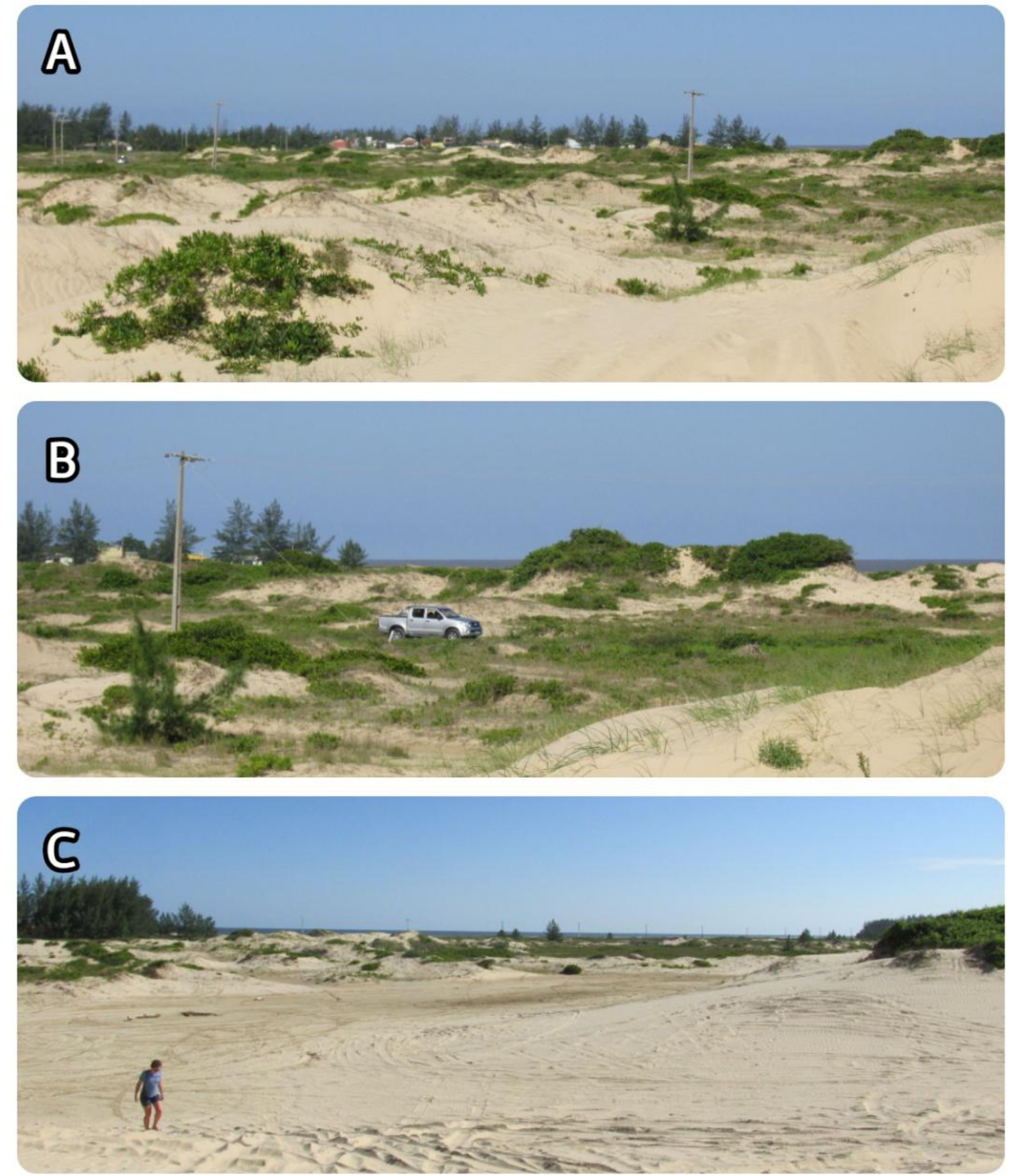

Figura 14 - Geossítio "Campo de dunas ativas do Araçá"._A) Vista geral do campo de dunas ativas do Araçá. Ao fundo observam-se diversas residências; B) Veículos em trânsito pelo campo de dunas, sem limitação de acesso; C) Dunas parabólicas e barcanas, que constituem o campo de dunas. 
Geossítio "Processos sedimentares da desembocadura do Rio Ribeira de lquape"

Localização geográfica: -24.6720336, -47.4203017

Tipologia: Área

Proteção legal: APA - Cananeia Iguape e Peruíbe.

Litotipo predominante: Sedimentos quartenários

Unidade Perrota et al. (2005): Coberturas Cenozoicas

Este geossítio localiza-se na região que cobre as imediações do canal do Valo Grande, em Iguape, até a desembocadura do Icapara, entre a ponta nordeste da Ilha Comprida e sul de Iguape, onde deságua o rio Ribeira de Iguape, um dos principais rios da região. Um bom ponto de observação da área é o mirante do Cristo localizado no morro do Espia, que também é um geossítio (Flg.15A).

O geossítio está relacionado com os processos fluviais e costeiros causados pela abertura do canal Valo Grande em 1852. Como visto anteriormente, desde então, apesar de ter sido uma atividade antropogênica, os processos decorrentes dessa obra se deram de forma natural e modificaram significativamente a paisagem na região. Estes processos serão descritos a seguir.

Segundo Gianinni et al. (2018) a abertura do canal acarretou em consequências hidrodinâmicas, geomorfológica-sedimentológicas, além de interferir sobre os ecossistemas da região.

Mudanças hidrodinâmicas - Ocorrem principalmente em virtude do aumento da vazão média anual do rio Ribeira de Iguape ao longo do canal, o que resultou na erosão das suas margens devido alto fluxo de energia(Fig.15C). A largura do Valo Grande que era de 4 metros em 1860, aumentou e atualmente em alguns locais atinge 300 metros (Fig. 15B) (Giannini et al., 2018). Nas últimas décadas, a taxa de alargamento do canal alcançou um estado de equilíbrio, provavelmente devido à estabilidade do fluxo e ao processo de formação do delta intralagunar próximo à desembocadura do Icapara (Italiani e Mahiques, 2014). A vazão do rio Ribeira de Iguape pelo canal chega a cerca de $70 \%$ via desembocadura de Icapara e apenas $30 \%$ pelo curso original do rio via desembocadura do Ribeira (Giannini et al., 2018).

Consequências geomorfológicas-sedimentológicas - Referem-se ao assoreamento junto à foz do canal devido ao aumento do aporte de sedimentos e à desaceleração do fluxo do rio. De 1860 a 1911, o Valo despejou aproximadamente 
4.2000.000 $\mathrm{m}^{3}$ de areia de suas margens erodidas (GEOBRÁs, 1966), o que ocasionou à formação de pequenas ilhas e de um delta na desembocadura do rio $\mathrm{e}$ no crescimento acelerado da parte norte da Ilha Comprida. Além disso, a mudança na dinâmica sedimentar resultou no desaparecimento da praia do Leste, em Iguape (Gianinni et al., 2018; Nascimento, 2004).(Fig A)

Consequências para os ecossistemas - Os ecossistemas localizados entre 0 canal e a desembocadura do rio Ribeira de Iguape apontam mudanças drásticas na salinidade da água, nos padrões de sedimentação e no aporte de metais (Mahiques et al., 2009). O Mar Pequeno, a nordeste, começou a receber mais água doce e avança até a região de Pedrinhas. A desembocadura original do rio Ribeira de Iguape passou a ter maior concentração de água salgada, pois perdeu $70 \%$ de sua vazão para a abertura do canal. Esse fato ocasionou a diminuição ou até mesmo o desaparecimento dos mangues, dos mariscos e dos peixes de água salgada na região do Mar Pequeno e, provavelmente, de Pedrinhas e Icapara, e aumentaram, nas áreas próximas, a desembocadura do rio Ribeira (Giannini et al. 2018).

Esse geossítio tem potencial de uso educativo voltado para alunos do ensino fundamental II, pois pode demonstrar processos sedimentares naturais ocasionados por intervenção antrópica. Também possui potencial turístico, visto que a parte em que a ilha cresceu é frequentemente utilizados por visitantes da praia.

Vulnerabilidade natural: Média

Vulnerabilidade antrópica: Alta

Fragilidade: Baixa 

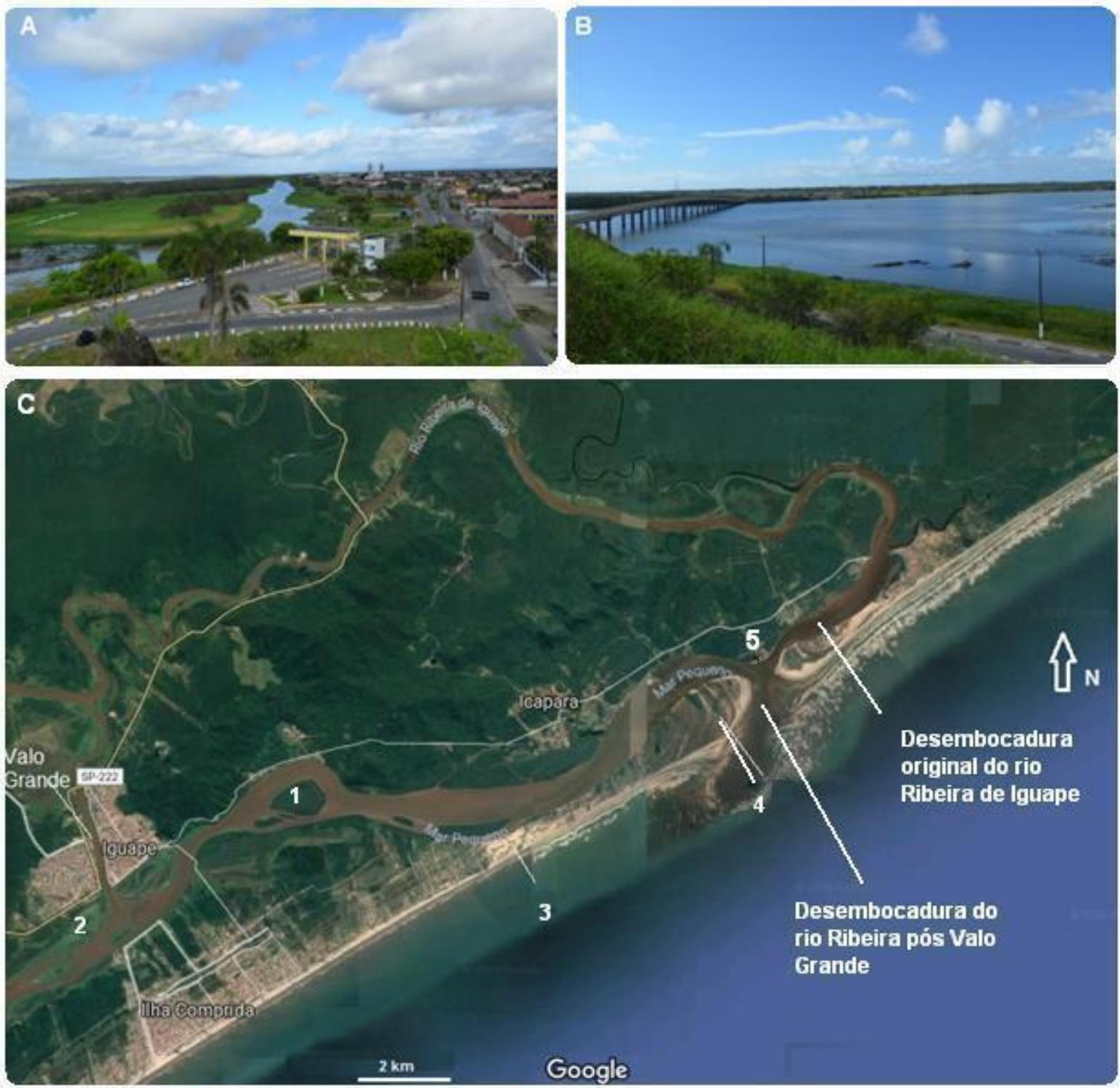

Figura 15 - Geossítio Processos sedimentares da desembocadura do rio Ribeira de Iguape”. A) À esquerda do Valo Grande, observa-se ilha fluvial em meio ao canal, ao lado do centro histórico; B) Ponte que interliga os municípios de lguape e llha Comprida; C) Localização dos processos causados pela abertura do Valo. 1formação de delta 2- formação de ilhas causadas pelo excesso de sedimentos, 3erosão no campo de dunas, 4 - linhas de crescimento longitudinais da ilha, pós Valo Grande. 5 - Local onde se encontrava a praia do leste. 


\subsubsection{CG - Geomorfologia e evolução da paisagem}

$\underline{\text { Geossítio "Maciço da Jureia" }}$

Localização geográfica: -24,570978165, -47,237323761

Tipologia: Ponto

Proteção legal: Estação Ecológica Jureia-Itatins

Litotipo predominante: Paragnaisses

Unidade Perrota et al. (2005): Complexo Atuba, Unidade Gnáissica

O Maciço da Jureia localiza-se na cidade de Iguape. A partir do centro da cidade, pega-se a estrada do Icapara até a balsa. Já no inicio da praia da Jureia é possível observar a forma de relevo que corresponde ao maciço.

O geossítio está inserido no inventário do estado de São Paulo (Garcia et al. 2018) e apresenta interesse geomorfológico devido ao relevo formado a partir de rochas granítico/gnáissicas em meio à planície costeira.

De acordo com Ab'Saber (2007) o maciço é a maior paleoilha florestada do litoral paulista, que teria se separado da Serra dos Itatins por falhamentos do período Terciário e incorporada ao continente por processos deposicionais marinhos durante o Pleistoceno Superior e boa parte do Holoceno, predominando extensos setores de sedimentação. O mesmo autor afirma que esse é "o segundo maciço elevado, de tipo horst, de toda a fachada tropical Atlântica de São Paulo".

Esse geossítio foi tombado pelo CONDEPHAAT, na resolução 11 de 25/7/1979, como bem cultural de interesse paisagístico e cientifico, pois possui individualidade geológica e morfológica próprias, além da rica biodiversidade representativa da Mata Altântica. A resolução considera que o maciço "constitui-se, por suas condições paisagísticas e topográficas, como elemento de inegável interesse à cultura, à história e ao turismo do Estado de São Paulo." (CONDEPHAAT).

Esse geossítio possui potencial educativo voltado para ensino superior, pois ajuda a compreender os processos tectônicos e sedimentares da formação da planície costeira da região.

O potencial turístico se justifica pela beleza cênica, pois a praia da Jureia é um ótimo local de observação desse geossítio(Fig 16A). Além disso, no maciço está 
situada a trilha do Imperador (Fig.16B), existente desde o inicio da colonização e que recebe esse nome por ter servido de passagem para o Imperador D. Pedro II em suas expedições pelo litoral. Antes disso a trilha recebia o nome de Trilha do Telegráfo por ter sido fortemente utilizada durante a Guerra do Paraguai. Ao longo da trilha é possível observar blocos de contenção de concreto e ruínas do antigo telégrafo, construídos por escravos no século XIX, o que define sua relevância nos aspectos históricos e culturais (Prefeitura de Iguape).

Vulnerabilidade natural: Baixa - feição geomorfológica de grandes dimensões Vulnerabilidade antrópica: Baixa

Fragilidade: Baixa
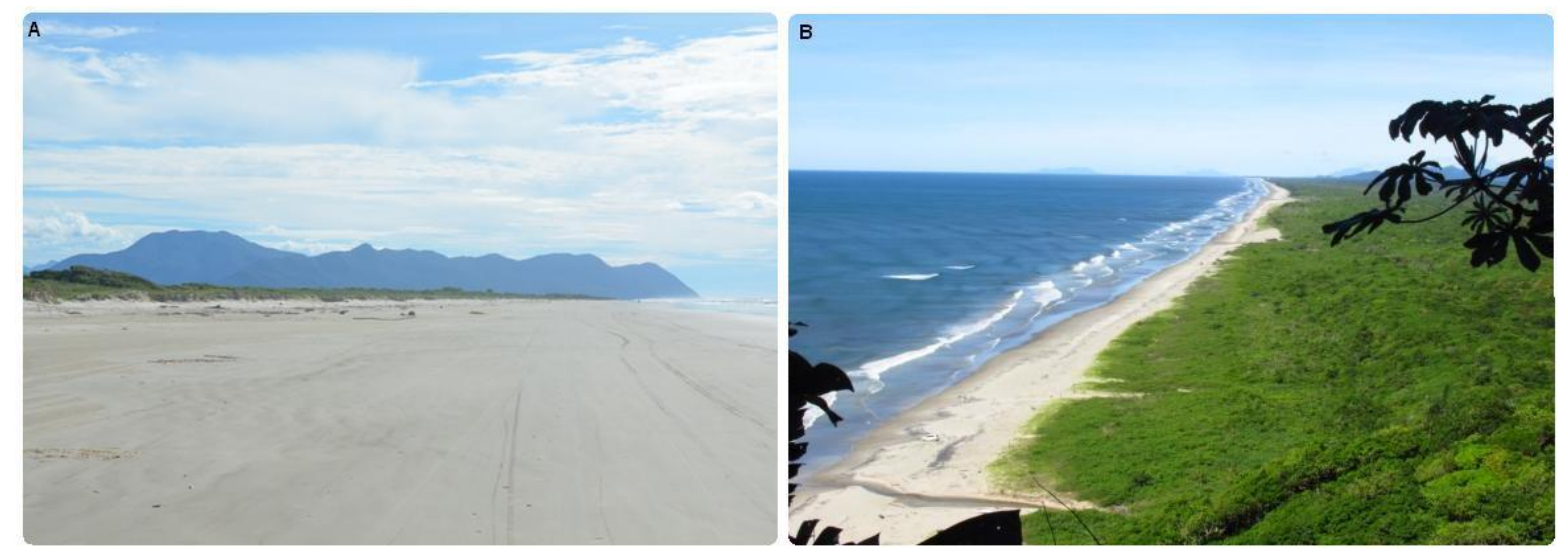

Figura 16 - Geossítio "Maciço da Jureia" A) Vista do maciço a partir da praia da Jureia; B) Vista da praia da Jureia por um mirante no Maciço. 


\section{Geossítio "Morro do Espia"}

Localização geográfica: -24.704560, -47.547639

Tipologia: Área

Proteção legal: APA Lagamar Cananeia, Iguape e Peruíbe

Litotipo predominante: Granito tipo Iguape

Unidade Perrota et al. (2005): Unidades Gnáissicas

O Morro do Espia é um maciço localizado próximo ao centro do município de Iguape. Constitui-se num representante do relevo granítico formado pelo granito Iguape, que se destaca na paisagem da planície costeira (Fig.17 A).

Ab'Saber (2007) afirma que, no Pleistoceno Superior e parte do Holoceno, esse maciço era uma ilha montanhosa que, posteriormente, foi incorporada à linha de costa por processos sedimentares.

Além da feição geomorfológica, constitui-se em mirante do qual é possível observar a planície costeira com as serranias ao fundo, as cidades de Iguape e parte da Ilha Comprida e o Valo Grande (Fig. 17 B).

No morro foi criado um parque municipal e um mirante no topo, o Mirante do Cristo. O geossítio possui potencial turístico, pois além do parque e do mirante, durante a Festa do Senhor Bom Jesus de Iguape recebe milhares de romeiros que passam por ali e acendem suas velas. Trata-se de um ótimo local para abordar questões geológicas, históricas e culturais. O local também recebe frequentemente grupos de alunos, tanto secundaristas como universitários. Portanto, possui potencial educativo também.

Vulnerabilidade natural: Baixa

Vulnerabilidade antrópica: Baixa

Fragilidade: Baixa 


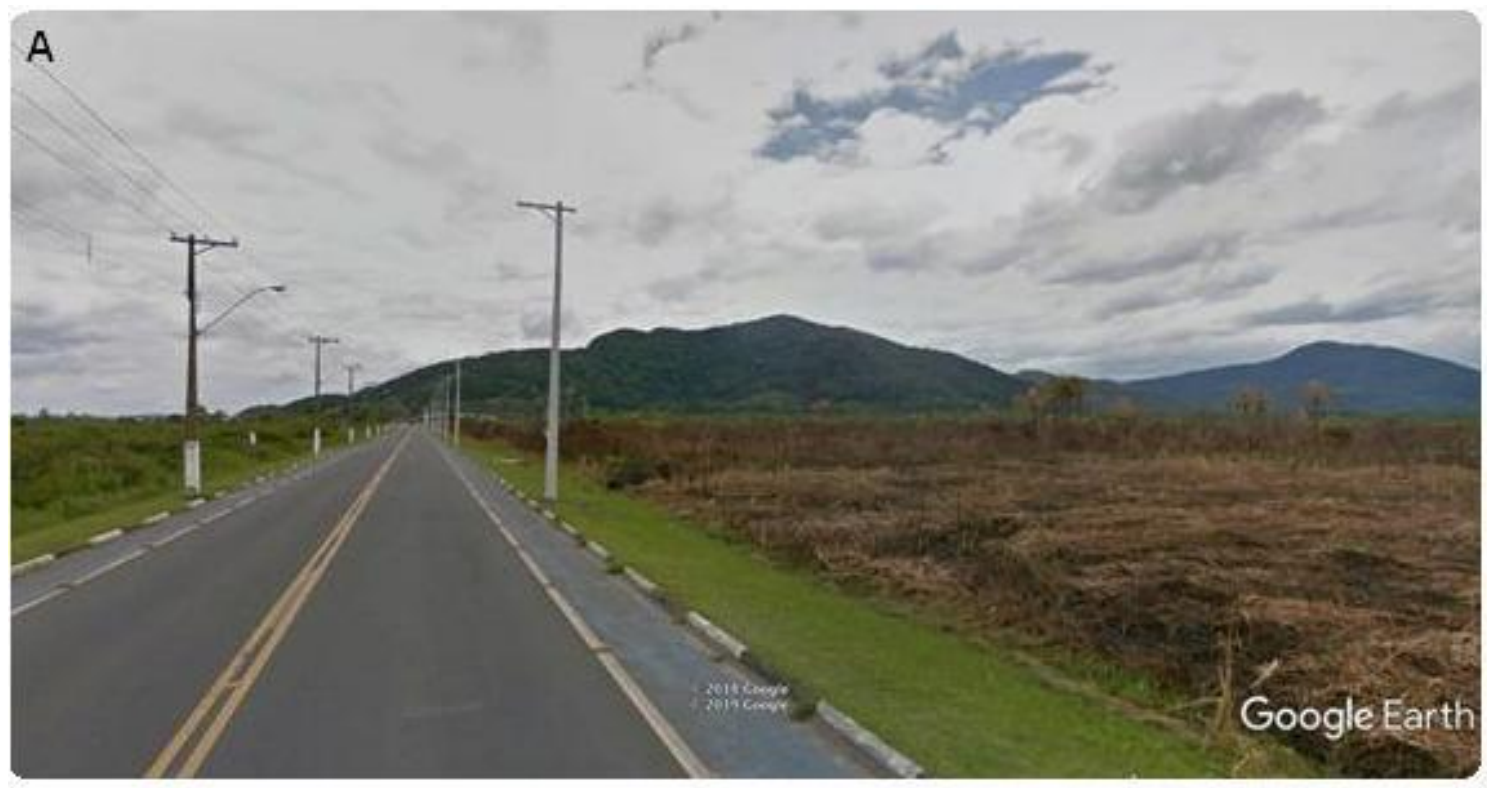

B

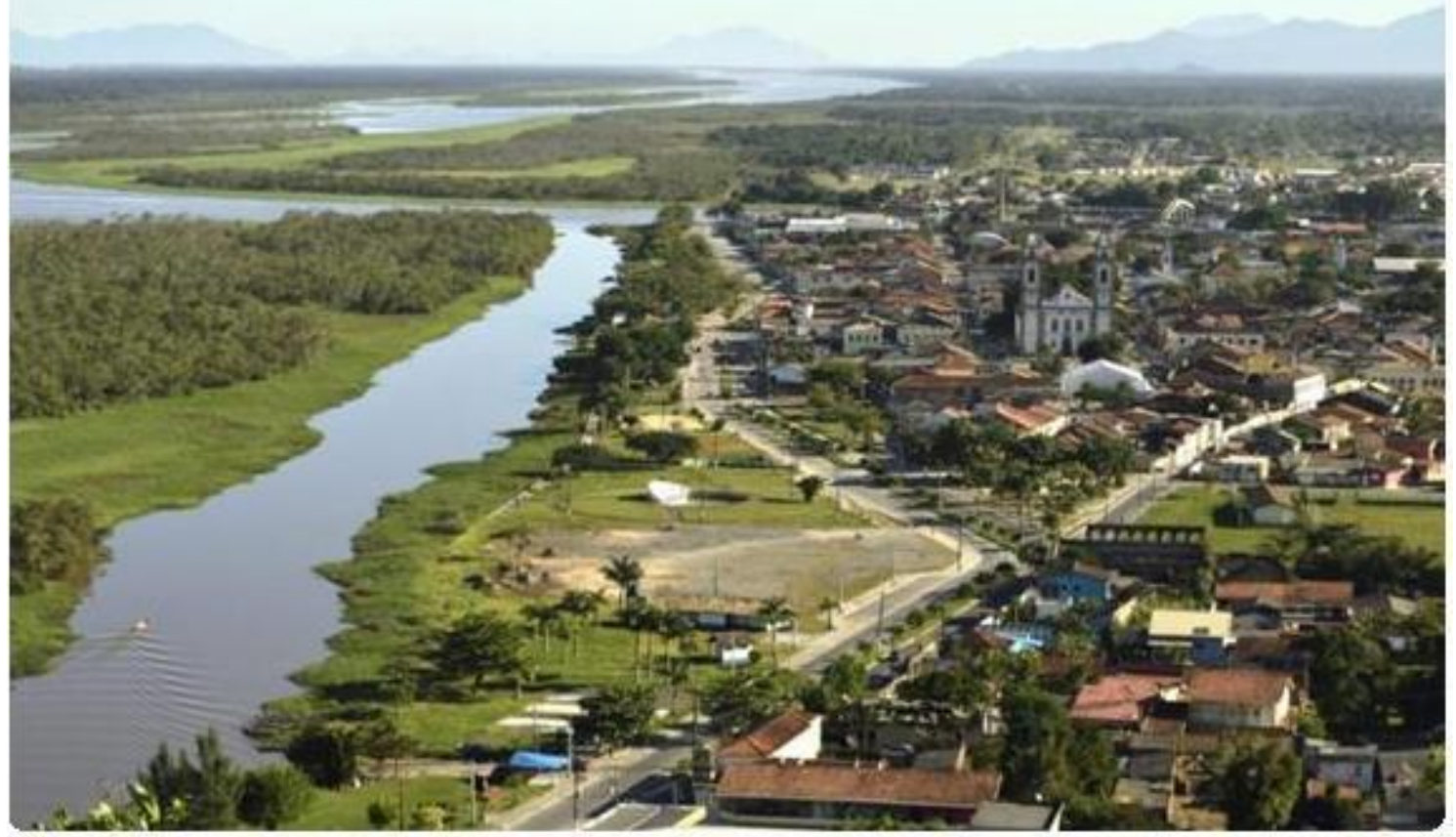

Figura 17 - Geossítio "Morro do Espia. A) Vista da llha Comprida para o Morro do Espia; B) Vista do mirante do Cristo para a cidade de Iguape, localizado no Morro do Espia. É possível observar, do mirante, a planície costeira e as serranias ao fundo. A esquerda da foto encontra-se o Valo Grande. Foto B: Thomas Akabane. 
Localização geográfica: -24.570978165, -47.237323761

Tipologia: Ponto

Proteção legal: Estação Ecologia Jureia-Itatins

Litotipopredominante: Paragnaisses

Unidade Perrota et al. (2005): Complexo Atuba, Unidade Gnáissica

O acesso ao geossítio inicia-se no fim da praia da Jureia, no município de Iguape, no núcleo prelado da EEJI, onde é possível conseguir a autorização para a trilha da Cachoeira Grande. A trilha se faz somente a pé e tem aproximadamente 1,4 $\mathrm{km}$.

A Cachoeira Grande possui aproximadamente 20 metros de queda d'água (Fig.18D). É composta por rochas paragnáissicas intensamente dobradas. Dobras intrafoliais caracterizam uma foliação pretérita deformada no evento que gerou a foliação principal (Fig. 18B). Ocorrem boudins centimétricos a métricos concordantes com a foliação (Fig. 18A). Diques máficos com direção N40W cortam todo o conjunto (Fig. 18A).

O sítio possui potencial turístico, pois a cachoeira é um atrativo procurado por turistas, além de exibir uma diversa vegetação de Mata Atlântica, e também para se acessar a cachoeira é necessário passar por um trecho da Trilha do Imperador.

Vulnerabilidade natural: Baixa

Vulnerabilidade antrópica: Baixa - necessário o acompanhamento por guia Fragilidade: Baixa 

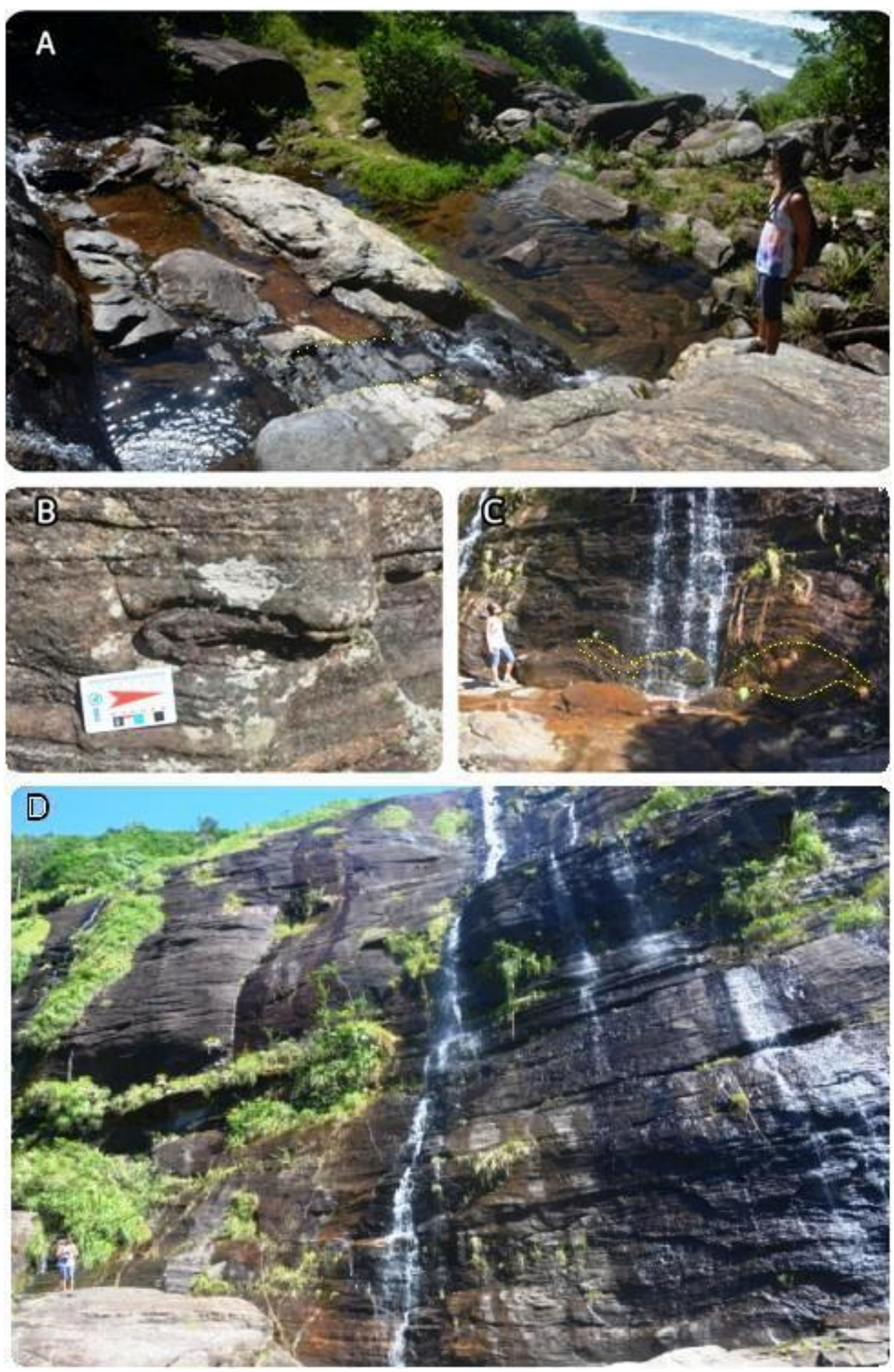

Figura 18 - - Sítio da Geodiversidade "Paragnaisses da Cachoeira Grande". A) Vista da cachoeira Grande, com detalhe para o dique de rocha máfica; B) Dobra intrafolial no paragnaisse; C) Boudins de rocha máfica; D) Vista do afloramento da Cachoeira Grande. 


\section{AVALIAÇÃO QUANTITATIVA}

A avaliação quantitativa foi feita utilizando a plataforma GEOSSIT desenvolvida pelo Serviço Geológico do Brasil. Nessa etapa verifica-se os valores numéricos de cada local quanto a sua relevância cientifica, uso potencial educativo e turístico e risco de degradação. Após a realização do inventário, foram quantificados 12 geossítios e um sítio da geodiversidade, que colaboram para o entendimento da história geológica da região.

O GEOSSIT disponibiliza também resultados referentes à avaliação da prioridade de proteção, realizada com base no método de Garcia-Cortés e Carcavilla (2009). Os valores obtidos indicam a prioridade através da soma do valor científico com o risco de degradação, formando assim um ranking. De acordo com a plataforma, através do valor de prioridade é possível avaliar o prazo de proteção desses locais que podem ser classificados em: Longo (<300); Médio (300-550); Curto(550-750); e Urgente (>700).

A seguir serão especificados os valores da avaliação quantitativa dos locais de interesse geológico da região estudada.

\subsection{Resultados da avaliação quantitativa}

Os resultados da avaliação quantitativa do valor científico estão apresentados na Tabela 9. Através de sete parâmetros pontuados com valores de 0 a 4 , o valor total determinou um ranking dos sítios de maior relevância cientifica, classificados posteriormente como relevância regional, nacional e internacional. 
Tabela 9 - Resultados da avaliação quantitativa de valor científico dos locais de interesse geológico de Iguape e llha Comprida de acordo com a plataforma GEOSSIT. * Sítio da geodiversidade.

\begin{tabular}{|c|c|c|c|c|c|c|c|c|c|c|c|}
\hline & Sitio & A1 & A2 & A3 & A4 & A5 & A6 & A7 & $\begin{array}{l}\text { Total do } \\
\text { valor } \\
\text { científico }\end{array}$ & Posição & Relevância \\
\hline 1 & Morro do Espia & 4 & 0 & 0 & 4 & 1 & 4 & 4 & 305 & $5^{\circ}$ & Internacional \\
\hline 2 & Maciço da Jureia & 4 & 0 & 4 & 4 & 1 & 4 & 4 & 305 & $5^{\circ}$ & Internacional \\
\hline 3 & $\begin{array}{c}\text { Processos } \\
\text { sedimentares da } \\
\text { desembocadura } \\
\text { do rio Ribeira de } \\
\text { lguape }\end{array}$ & 4 & 0 & 4 & 4 & 4 & 4 & 4 & 320 & $2^{\circ}$ & Internacional \\
\hline 4 & $\begin{array}{l}\text { Campo de dunas } \\
\text { ativas do Araçá }\end{array}$ & 4 & 0 & 4 & 4 & 2 & 4 & 4 & 310 & $4^{\circ}$ & Internacional \\
\hline 5 & $\begin{array}{c}\text { Dunas, } \\
\text { paleodunas e } \\
\text { paleolagunas da } \\
\text { llha Comprida }\end{array}$ & 4 & 2 & 4 & 2 & 4 & 4 & 4 & 330 & $1^{\circ}$ & Internacional \\
\hline 6 & $\begin{array}{c}\text { Terraços } \\
\text { holocênicos do } \\
\text { Pontal da } \\
\text { Trincheira }\end{array}$ & 4 & 0 & 2 & 2 & 4 & 2 & 4 & 250 & $10^{\circ}$ & Nacional \\
\hline 7 & $\begin{array}{l}\text { Cordões } \\
\text { litorâneos e } \\
\text { paleodunas } \\
\text { da praia da } \\
\text { Jureia }\end{array}$ & 4 & 0 & 2 & 2 & 4 & 4 & 4 & 280 & $7^{\circ}$ & Nacional \\
\hline 8 & $\begin{array}{l}\text { Intrusão alcalina } \\
\text { da llha Comprida }\end{array}$ & 4 & 0 & 2 & 2 & 1 & 4 & 4 & 265 & $8^{\circ}$ & Nacional \\
\hline 9 & $\begin{array}{c}\text { Granito lguape } \\
\text { com feições } \\
\text { miloníticas }\end{array}$ & 4 & 0 & 2 & 2 & 1 & 2 & 2 & 215 & $12^{\circ}$ & Nacional \\
\hline 10 & $\begin{array}{c}\text { Granito lguape } \\
\text { no Morro do } \\
\text { Espia }\end{array}$ & 4 & 0 & 2 & 4 & 2 & 2 & 2 & 250 & $10^{\circ}$ & Nacional \\
\hline 11 & $\begin{array}{c}\text { Granulitos do } \\
\text { Complexo } \\
\text { Itatins na } \\
\text { Cachoeira do } \\
\text { Paraíso }\end{array}$ & 4 & 0 & 2 & 4 & 4 & 2 & 2 & 260 & $9^{\circ}$ & Nacional \\
\hline 12 & $\begin{array}{c}\text { Paragnaisses da } \\
\text { Praia da Jureia }\end{array}$ & 4 & 0 & 4 & 4 & 4 & 4 & 4 & 320 & $2^{0}$ & Internacional \\
\hline 13 & $\begin{array}{c}\text { Paragnaisses da } \\
\text { Cachoeira } \\
\text { Grande }\end{array}$ & 2 & 0 & 0 & 4 & 4 & 2 & 1 & 180 & $13^{\circ}$ & Nacional \\
\hline
\end{tabular}

A avaliação do risco de degradação visa ordenar a prioridade de futuras estratégias de geoconservação por meio de 5 parâmetros. $O$ resultado final indica que o local pode ter baixo risco (<200), médio (201-300) e alto (301-400) (tabela 10). 
Tabela 10 - Resultados da avaliação quantitativa do risco de degradação dos locais de interesse geológico de lguape e llha Comprida de acordo com a plataforma GEOSSIT. "Sítio da geodiversidade.

\begin{tabular}{|c|c|c|c|c|c|c|c|c|c|}
\hline & Sítio & B1 & B2 & B3 & B4 & B5 & $\begin{array}{l}\text { Total do } \\
\text { risco de } \\
\text { degradação }\end{array}$ & Posição & Resultado \\
\hline 1 & $\begin{array}{l}\text { Morro do } \\
\text { Espia }\end{array}$ & 4 & 0 & 4 & 2 & 1 & 190 & $8^{\circ}$ & Baixo \\
\hline 2 & Maciço da Jureia & 1 & 0 & 1 & 1 & 1 & 80 & 13 & Baixo \\
\hline 3 & $\begin{array}{l}\text { Processos sedimentares da } \\
\text { desembocadura do rio } \\
\text { Ribeira de lguape }\end{array}$ & 1 & 4 & 2 & 4 & 1 & 225 & $4^{\circ}$ & Médio \\
\hline 4 & $\begin{array}{l}\text { Campo de dunas } \\
\text { ativas do Araçá }\end{array}$ & 4 & 4 & 2 & 3 & 1 & 315 & $1^{\circ}$ & Alto \\
\hline 5 & $\begin{array}{c}\text { Dunas, paleodunas e } \\
\text { paleolagunas da llha } \\
\text { Comprida }\end{array}$ & 4 & 4 & 2 & 3 & 1 & 315 & $1^{\circ} \underline{0}$ & Alto \\
\hline 6 & $\begin{array}{l}\text { Terraços holocênicos do } \\
\text { Pontal da Trincheira }\end{array}$ & 4 & 4 & 2 & 1 & 1 & 285 & $5^{\circ}$ & Médio \\
\hline 7 & $\begin{array}{c}\text { Cordões litorâneos e } \\
\text { paleodunas da praia da } \\
\text { Jureia }\end{array}$ & 4 & 4 & 2 & 2 & 1 & 300 & 3은 & Médio \\
\hline 8 & $\begin{array}{c}\text { Intrusão alcalina da llha } \\
\text { Comprida }\end{array}$ & 1 & 4 & 2 & 2 & 1 & 195 & $7^{0}$ & Baixo \\
\hline 9 & $\begin{array}{c}\text { Granito Iguape com feições } \\
\text { miloníticas }\end{array}$ & 1 & 3 & 1 & 4 & 1 & 185 & 9o & Baixo \\
\hline 10 & $\begin{array}{l}\text { Granito Iguape no Morro do } \\
\text { Espia }\end{array}$ & 1 & 4 & 1 & 4 & 1 & 205 & $6^{\circ}$ & Médio \\
\hline 11 & $\begin{array}{c}\text { Granulitos do Complexo } \\
\text { Itatins na Cachoeira do } \\
\text { Paraíso }\end{array}$ & 1 & 1 & 1 & 1 & 1 & 100 & $11^{\circ}$ & Baixo \\
\hline 12 & $\begin{array}{l}\text { Paragnaisses da Praia da } \\
\text { Jureia }\end{array}$ & 1 & 1 & 2 & 1 & 1 & 120 & $10^{\circ}$ & Baixo \\
\hline 13 & $\begin{array}{c}\text { Paragnaisses da Cachoeira } \\
\text { Grande* }\end{array}$ & 1 & 1 & 1 & 0 & 1 & 85 & $12^{\circ}$ & Baixo \\
\hline
\end{tabular}

Os valores do resultado da avaliação quantitativa do potencial uso educativo (VE) e turístico (VT) estão especificados na Tabela 11. Essa avaliação estabelece 15 parâmetros, além da relevância regional ou nacional. 
Tabela 11 - Resultados da avaliação quantitativa do uso potencial educativo e turístico dos locais de interesse geológico de Iguape e llha Comprida de acordo com a plataforma GEOSSIT. *Sítio da geodiversidade.

\begin{tabular}{|c|c|c|c|c|c|c|c|c|c|c|c|c|c|c|c|c|c|}
\hline Sítio & 1 & 2 & 3 & 4 & 5 & 6 & 7 & 8 & 9 & 10 & 11 & 12 & 13 & 14 & 15 & VE & VT \\
\hline Morro do Espia & 0 & 4 & 4 & 2 & 4 & 1 & 4 & 3 & 2 & 4 & 2 & 3 & 3 & 1 & 4 & 260 & 265 \\
\hline $\begin{array}{l}\text { Maciço da } \\
\text { Jureia }\end{array}$ & 4 & 1 & 4 & 2 & 4 & 1 & 4 & 3 & 3 & 4 & 2 & 3 & 3 & 1 & 4 & 270 & 275 \\
\hline $\begin{array}{c}\text { Processos } \\
\text { sedimentares da } \\
\text { desembocadura } \\
\text { do rio Ribeira de } \\
\text { lguape }\end{array}$ & 4 & 4 & 4 & 2 & 4 & 1 & 4 & 1 & 4 & 4 & 2 & 3 & 2 & 1 & 4 & 300 & 285 \\
\hline $\begin{array}{c}\text { Campo de } \\
\text { dunas ativas do } \\
\text { Araçá }\end{array}$ & 1 & 4 & 4 & 2 & 4 & 1 & 4 & 2 & 3 & 4 & 2 & 2 & 4 & 1 & 4 & 260 & 280 \\
\hline $\begin{array}{c}\text { Dunas, } \\
\text { paleodunas e } \\
\text { paleolagunas } \\
\text { da Ilha } \\
\text { Comprida }\end{array}$ & 2 & 3 & 4 & 2 & 4 & 1 & 4 & 2 & 3 & 4 & 1 & 4 & 4 & 1 & 4 & 260 & 280 \\
\hline $\begin{array}{l}\text { Terraços } \\
\text { holocênicos do } \\
\text { Pontal da } \\
\text { Trincheira }\end{array}$ & 1 & 1 & 4 & 2 & 4 & 1 & 4 & 2 & 2 & 3 & 2 & 4 & 3 & 1 & 4 & 235 & 225 \\
\hline $\begin{array}{l}\text { Cordões } \\
\text { litorâneos e } \\
\text { paleodunas } \\
\text { da praia da } \\
\text { Jureia }\end{array}$ & 2 & 2 & 4 & 2 & 4 & 1 & 4 & 3 & 3 & 4 & 2 & 3 & 3 & 1 & 4 & 265 & 275 \\
\hline $\begin{array}{l}\text { Intrusão } \\
\text { alcalina da Ilha } \\
\text { Comprida }\end{array}$ & 4 & 2 & 4 & 2 & 4 & 1 & 3 & 0 & 2 & 3 & 1 & 2 & 2 & 1 & 4 & 220 & 220 \\
\hline $\begin{array}{l}\text { Granito lguape } \\
\text { com feições } \\
\text { miloníticas }\end{array}$ & 3 & 4 & 3 & 2 & 4 & 1 & 4 & 0 & 1 & 2 & 1 & 1 & 1 & 1 & 3 & 205 & 200 \\
\hline $\begin{array}{c}\text { Granito lguape } \\
\text { no Morro do } \\
\text { Espia }\end{array}$ & 2 & 4 & 2 & 2 & 4 & 1 & 3 & 0 & 2 & 3 & 1 & 2 & 2 & 1 & 3 & 210 & 205 \\
\hline $\begin{array}{l}\text { Granulitos do } \\
\text { Complexo } \\
\text { Itatins na } \\
\text { Cachoeira do } \\
\text { Paraíso }\end{array}$ & 4 & 2 & 2 & 4 & 4 & 1 & 4 & 2 & 2 & 4 & 2 & 3 & 3 & 1 & 4 & 285 & 280 \\
\hline $\begin{array}{c}\text { Paragnaisses } \\
\text { da Praia da } \\
\text { Jureia }\end{array}$ & 4 & 1 & 4 & 2 & 4 & 1 & 4 & 3 & 2 & 4 & 1 & 2 & 2 & 1 & 4 & 240 & 265 \\
\hline $\begin{array}{c}\text { Paragnaisses } \\
\text { da Cachoeira } \\
\text { Grande* }^{\star}\end{array}$ & 4 & 0 & 2 & 2 & 4 & 1 & 3 & 1 & 2 & 4 & 2 & 2 & 3 & 1 & 4 & 225 & 220 \\
\hline
\end{tabular}




\subsection{Discussão dos resultados}

Após a conclusão do inventário e da avaliação quantitativa apresentada anteriormente, 12 geossítios e um sítio da geodiversidade foram selecionados e quantificados. Dentre estes, 3 geossítios foram classificados com relevância internacional e os demais com relevância nacional, incluindo o sítio da geodiversidade.

\subsubsection{Valor científico e risco de degradação}

O local que alcançou maior pontuação no valor cientifíco foi o geossítio "Dunas, paleodunas e paleolagunas da llha Comprida". Apesar de não estarem muito bem protegidas contra as ameaças antrópicas e naturais, as principais feições geológicas se mantêm íntegras e representam os melhores exemplos de dunas e paleodunas do estado. As dunas e os cordões litorâneos ao longo da praia também foram utilizados para estudos sobre a evolução geológica da ilha e para definir uma unidade litoestratigráfica, sendo o único sítio a ganhar pontuação no parâmetro A2 (local-tipo). Esse geossítio foi tema de diversas publicações, tanto nacionais quanto internacionais sendo, portanto, classificado com relevância internacional. O risco de degradação desse geossítio também é o mais alto, ficando em primeiro lugar no ranking.

Na segunda posição estão os geossítios "Paragnaisses da praia da Jureia" e "Processos sedimentares da desembocadura do rio Ribeira de lguape". Esses locais receberam nota máxima em quase todos os parâmetros, exceto no A2, que não se aplica, obtendo, portanto, relevância internacional.

Em quarto lugar, o geossítio "Campo de dunas ativas do Araçá" foi classificado com relevância internacional. Esse local recebeu nota baixa nos parâmetros (A2) local-tipo e diversidade geológica (A5).

Os geossítios "Maciço da Jureia" e "Morro do Espia" obtiveram o quinto lugar. Recebem notas baixas por não serem locais-tipo e por terem pouca diversidade geológica. Os geossítios foram classificados com relevância internacional. 
Classificado em sétimo lugar e com relevância nacional, o geossítio "Cordões litorâneos e paleodunas da praia da Jureia” recebeu esse resultado principalmente por não estar muito preservado, embora as principais feições estejam em bom estado de observação. Também não possui publicações internacionais ou em livro e não é um local-tipo.

O geossítio "Intrusão alcalina da Ilha Comprida" obteve a oitava colocação, resultado que se deve ao fato do geossítio não ser um local-tipo, as publicações sobre esse local serem nacionais, o local não estar muito preservado por conta da densa vegetação que cobre o afloramento e por não ter muitos tipos diferentes de aspectos geológicos.

Em nono lugar ficou o geossítio "Granulitos do Complexo Itatins na Cachoeira do Paraíso". Este geossítio recebeu baixa pontuação por não ter publicações internacionais, por não ser um exemplo raro na região, além de estar inserido em uma UC que possui limitação de uso, o que diminui a pontuação. Apesar disso, é o melhor exemplo do Complexo Itatins no município de Iguape.

Os geossítios "Terraços holocênicos do Pontal da Trincheira" e "Granito Iguape no Morro do Espia" ficaram em décimo lugar. O geossítio "Terraços holocênicos do Pontal da Trincheira" recebeu essa classificação por não estar muito bem preservado e por ser de alta vulnerabilidade e fragilidade tanto natural quanto antrópica. O local teve baixa pontuação nos parâmetros A5 e A6 por não ter uma grande diversidade de aspectos geológicos e por não ser o único exemplo na área de estudo, visto que em outros locais da ilha também há terraços desse tipo, embora estejam em área ou residência com difícil acesso e/ou sem ótimos pontos de observação.

O geossítio "Granito Iguape no Morro do Espia” teve baixa pontuação porque existem somente publicações nacionais sobre a temática do sítio e por possuir pouca diversidade geológica, além de ser necessária autorização para entrar, pois é uma área particular.

O "Granito Iguape com feições miloníticas" é o geossítio que recebeu menor pontuação, ficando em última colocação no ranking dos geossítios. Esse resultado decorre pelo fato de não existirem publicações internacionais sobre o geossítio, sua integridade não estar muito bem preservada, o geossítio estar muito intemperizado, existir pouca diversidade geológica,e por não ser um exemplo único na região. $\mathrm{O}$ 
local situa-se numa propriedade particular, sendo necessária autorização, o que diminui a sua pontuação.

O sítio "Paragnaisses da Cachoeira Grande" foi classificado como sitio da geodiversidade de relevância nacional, principalmente por não existirem publicações cientificas no local e também por não ser um local-tipo. Além disso, existem limitações de uso, sendo necessária autorização do parque para visitar.

Os resultados da quantificação do risco de degradação não foram coerentes para os geossítios "Terraços holocênicos do Pontal da Trincheira" e "Cordões litorâneos e paleodunas da praia da Jureia", esses locais possuem alta vulnerabilidade e fragilidade natural, decorrentes inclusive das mudanças climática que já demonstram alterações nesses locais, porém na quantificação esse fator não é levado em consideração. A vulnerabilidade e fragilidade antrópica são altas também, por serem locais que já recebem muitos turistas e por mais que a densidade populacional dos municípios seja menos de 100 habitantes por $\mathrm{km}^{2}$ (parâmetro B5), durante a temporada a população chega a ser o triplo, esse também é outro fator que não é levado em consideração no método aplicado, pois lugares turísticos atraem pessoas de todos os tipos e são turistas que desconhecem a realidade e fragilidade do ambiente o que aumenta ainda mais o risco de degradação,

No gráfico abaixo observa-se a relação do valor cientifico e do risco de degradação dos geossítios (Fig. 19). Nota-se que os geossítios 3, 4, 5 e 7 são os que obtiveram maior valor cientifico em relação ao risco de degradação. Todos esses locais pertencem à categoria geológica "Evolução Quaternária", o que indica uma significativa prioridade de proteção para os geossítios desta categoria. 


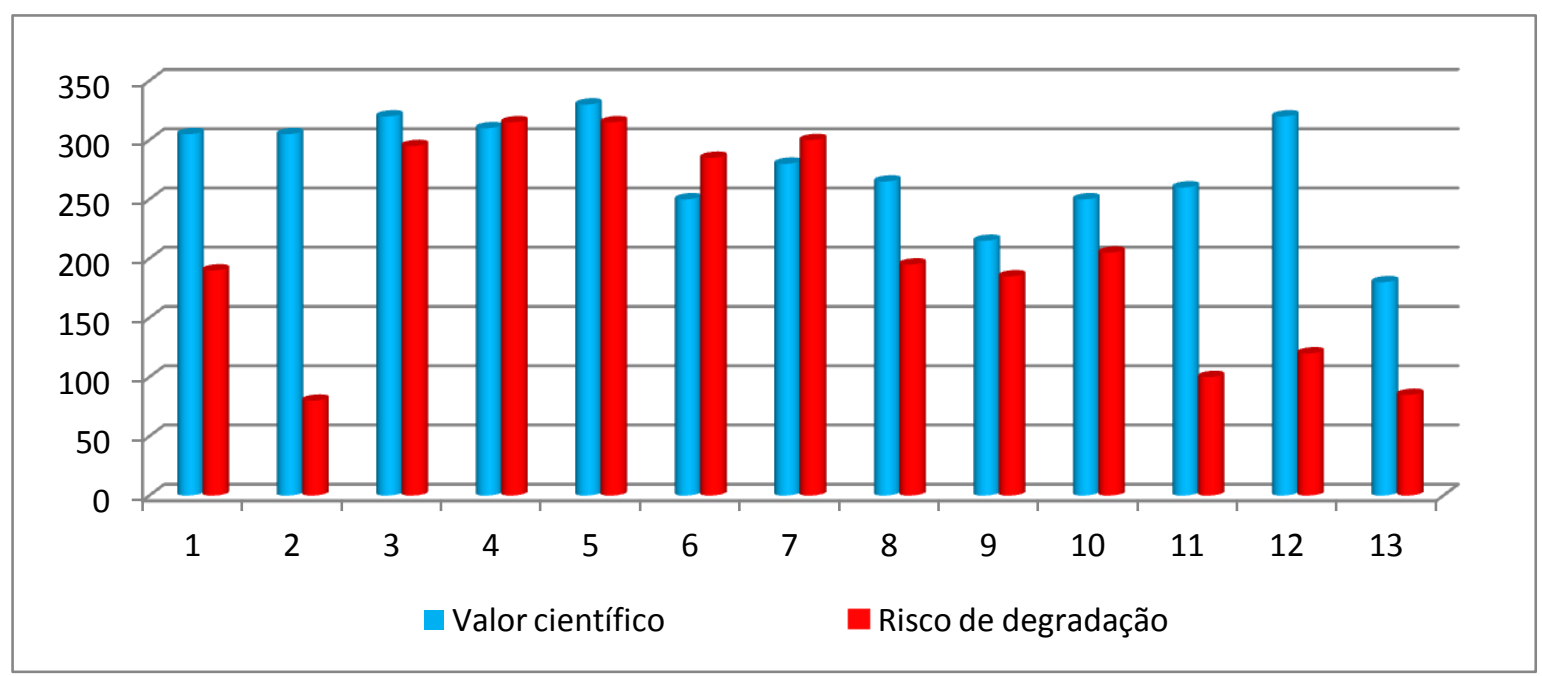

Figura 19 - Relação do valor científico e risco de degradação dos geossítios e sítio da geodiversidade. Os locais estão numerados de 1 a 13 conforme tabelas 10 e 11 .

O ranking dos sítios com maior prioridade de proteção estão especificados na tabela 12. Os sítios $5,4,3$ e 7 foram os primeiros colocados na posição de prioridade de proteção. Para os geossítios 4,5 e 7 a necessidade de proteção seria a curto prazo, pois são locais com alto valor científico e alto risco de degradação. Além disso, não possuem limite de acesso, ou seja, existe possibilidade de deterioração dos elementos geológicos por causas antrópicas.

Tabela 12 - Prioridade de proteção científica e prazo de proteção dos locais de interesse geológico dos municípios de lguape e llha Comprida. "Sítio da geodiversidade.

\begin{tabular}{|c|c|c|c|c|}
\hline & Sítio & $\begin{array}{l}\text { Prioridade de } \\
\text { proteção científica }\end{array}$ & Ranking & $\begin{array}{l}\text { Prazo de } \\
\text { Proteção }\end{array}$ \\
\hline 1 & $\begin{array}{l}\text { Morro do } \\
\text { Espia }\end{array}$ & 495 & $6^{\circ}$ & Médio \\
\hline 2 & Maciço da Jureia & 385 & $11^{\circ}$ & Médio \\
\hline 3 & $\begin{array}{c}\text { Processos sedimentares } \\
\text { da desembocadura do rio } \\
\text { Ribeira de Iguape }\end{array}$ & 615 & $3^{\circ}$ & Médio \\
\hline 4 & $\begin{array}{l}\text { Campo de dunas } \\
\text { ativas do Araçá }\end{array}$ & 625 & $2^{\circ}$ & Curto \\
\hline
\end{tabular}


Continuação...

\begin{tabular}{|c|c|c|c|c|}
\hline & Sítio & $\begin{array}{c}\text { Prioridade de } \\
\text { proteção científica }\end{array}$ & Ranking & $\begin{array}{l}\text { Prazo de } \\
\text { Proteção }\end{array}$ \\
\hline 5 & $\begin{array}{c}\text { Dunas, paleodunas e } \\
\text { paleolagunas da llha } \\
\text { Comprida }\end{array}$ & 645 & $1^{0}$ & Curto \\
\hline 6 & $\begin{array}{l}\text { Terraços holocênicos do } \\
\text { Pontal da Trincheira }\end{array}$ & 535 & $5^{\circ}$ & Médio \\
\hline 7 & $\begin{array}{c}\text { Cordões litorâneos e } \\
\text { paleodunas da praia da } \\
\text { Jureia }\end{array}$ & 580 & $4^{\circ}$ & Curto \\
\hline 8 & $\begin{array}{l}\text { Intrusão alcalina da llha } \\
\text { Comprida }\end{array}$ & 460 & $7^{\circ}$ & Médio \\
\hline 9 & $\begin{array}{l}\text { Granito Iguape com } \\
\text { feições miloníticas }\end{array}$ & 400 & $10^{\circ}$ & Médio \\
\hline 10 & $\begin{array}{c}\text { Granito Iguape no Morro } \\
\text { do Espia }\end{array}$ & 455 & $8^{\circ}$ & Médio \\
\hline 11 & $\begin{array}{c}\text { Granulitos do Complexo } \\
\text { Itatins na Cachoeira do } \\
\text { Paraíso }\end{array}$ & 360 & $12^{\circ}$ & Médio \\
\hline 12 & $\begin{array}{c}\text { Paragnaisses da Praia } \\
\text { da Jureia }\end{array}$ & 440 & $9^{\circ}$ & Médio \\
\hline 13 & $\begin{array}{l}\text { Paragnaisses da } \\
\text { Cachoeira Grande* }\end{array}$ & 265 & $13^{\circ}$ & Médio \\
\hline
\end{tabular}

\subsubsection{Potencial uso turístico e educativo}

Os resultados dos valores de uso potencial educativo e turístico estão apresentados na tabela 11 . Os locais de uso potencial educativo levam em consideração, principalmente, o potencial didático (parâmetro 11), a diversidade geológica (parâmetro 12) e por serem locais que não apresentam possibilidade de deterioração por atividades antrópicas direta. Os locais que apresentam maior potencial educativo são os geossítios "Processos sedimentares da desembocadura do rio Ribeira de Iguape", "Granulitos do Complexo Itatins na cachoeira Grande" e o "Maciço da Jureia".

O geossítio "Processos sedimentares da desembocadura do rio Ribeira de Iguape" é um sítio com alguns pontos de observação, um deles a ponta extrema da 
ilha, é uma região bastante visitada. Um dos melhores pontos de observação desse geossítio é do Mirante do Cristo, no topo do Morro do Espia. Desse mirante é possível observar os processos sedimentares causados pela abertura do Valo Grande, um dos primeiros desastres ambientais causados pelo homem no Brasil.

"Os Granulitos do Complexo Itatins na Cachoeira Grande" é um geossítio que representa o Complexo Itatins no município de Iguape, importante unidade geológica que tem suas feições muito bem preservadas e de fácil observação. Esse complexo é a unidade mais antiga do litoral paulista, formada no Paleoproterozoico, tendo sido afetada pelo ciclo Brasiliano, no Neoproterozoico. Esse sítio possui infraestrutura para receber turistas e estudantes e para entrar na área da cachoeira é preciso passar pela recepção do parque, onde há um monitor que passa informações sobre a trilha, além de questões de segurança. A sede do Parque Itinguçu possui salas para cursos e palestras, banheiros, lanchonetes ao lado e a trilha até o afloramento principal conta com escadas, corrimões, placas de sinalização e de conscientização ambiental. Durante a temporada, a cachoeira tem um limite de uso de 200 pessoas por dia.

O "Maciço da Jureia" é um geossítio de interesse geomorfológico, que se destaca no valor educativo por ter baixa vulnerabilidade, além de estar também associado com outros valores históricos e biológicos.

Os locais que apresentaram maior potencial turístico foram os geossítios "Processos sedimentares da desembocadura do rio Ribeira de lguape", "Campo de dunas ativas do Araçá", "Dunas, Paleodunas e Paleolagunas da Ilha Comprida" e "Granulitos do Complexo Itatins na Cachoeira Grande". Essa avaliação permite selecionar os locais potenciais para divulgação geocientifica, como a criação de roteiros geoturísticos. Esses locais apresentam, além de elevada beleza cênica, outros valores associados como históricos, arqueológicos, ecológicos e culturais.

Os sítios que receberam maior pontuação já recebem muitos turistas durante o ano, porém o geossítio "Campo de dunas ativas do Araçá" e "Dunas, Paleodunas e Paleolagunas da llha Comprida" possuem alto risco de degradação, sendo necessário prioridade de proteção em curto prazo.

No geossítio "Dunas, Paleodunas e Paleolagunas da llha Comprida" houve dificuldade em estabelecer o potencial de uso (parâmetro C2), pois esse geossítio é muito extenso e com vários pontos de observação, alguns localizados em área 
urbanizada com acesso via estrada asfaltada e outros ao longo da praia, sem asfalto mas com acesso a veículos. Considerou-se, então, que o local de interesse é acessível por veículos em estrada não asfaltada por ter a maioria dos pontos nessa área.

No gráfico abaixo (Fig.20) é possível analisar a relação dos valores de uso potencial educativo e turístico com o risco de degradação.

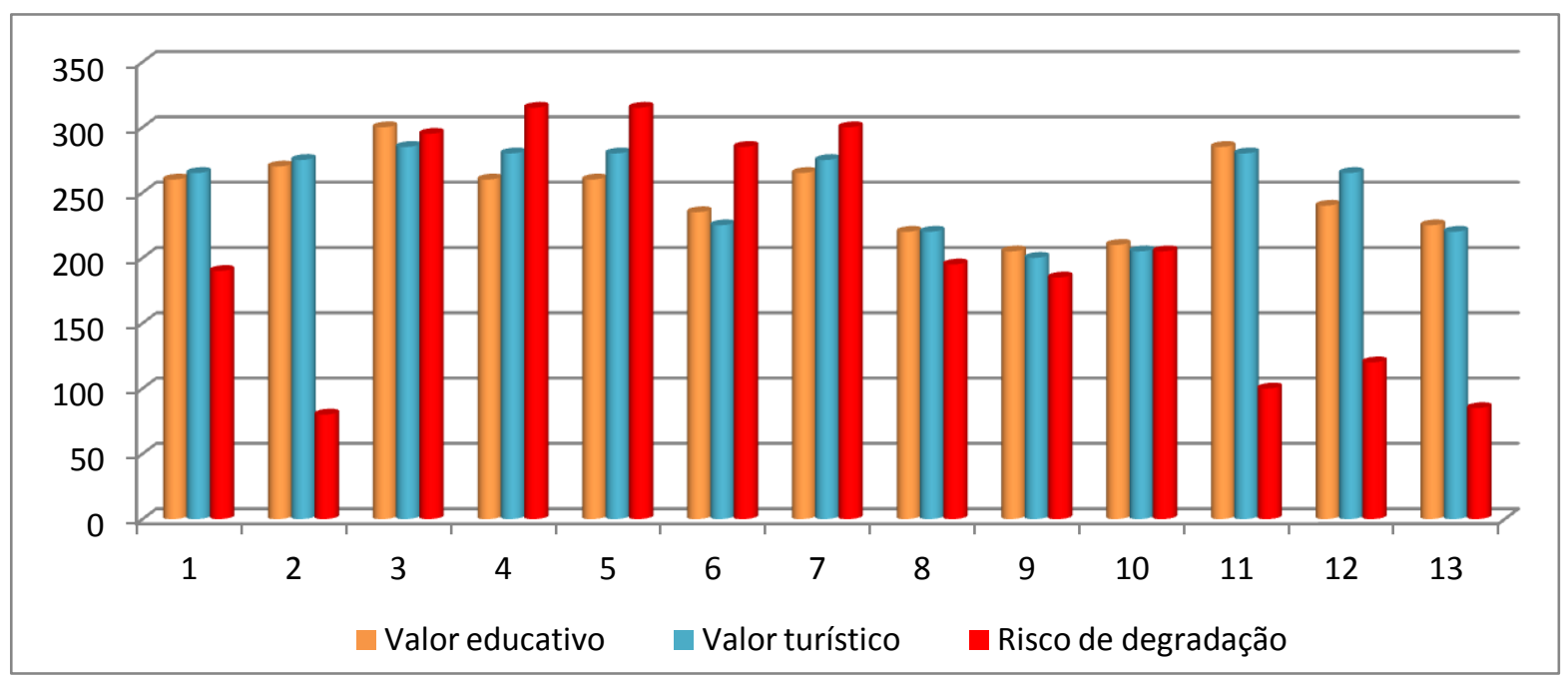

Figura 20 - Relação dos valores de uso potencial educativo e turístico e risco de degradação dos locais de interesse geológico dos municípios de Iguape e llha Comprida. Os locais estão numerados de 1 a 13 conforme tabela 10 e 11. 


\section{6 - PROPOSTAS DE USO E GESTÃo DOS LOCAIS DE INTERESSE GEOLÓGICO}

Os trabalhos de inventário e avaliação quantitativa dos locais de interesse geológico definidos em Iguape e llha Comprida permitiram tecer um diagnóstico sobre as potencialidades destes locais em relação ao uso científico, turístico e/ou educativo. Neste capítulo, os dados obtidos serão utilizados para estabelecer indicações de gestão e delinear propostas de uso turístico para estes locais.

\section{1 - Enquadramento Legal}

Como mencionado anteriormente, todos os locais de interesse geológico inventariados neste trabalho situam-se em unidades de conservação. A fim de fazer indicações de uso e gestão, é necessário i) Estabelecer quais unidades de conservação são responsáveis por gerir a área em que estão situados os sítios e; ii) Identificar qual o tipo de UC.

As unidades de conservação abrangem diversas categorias, cada uma com formas de manejo específicas, classificadas de acordo com suas características e tipos de uso. O Sistema Nacional de Unidades de Conservação (SNUC), instituído pela Lei Federal oㅜ 9.985, editada em 18 de julho de 2000, determina as bases para a estruturação do sistema de áreas protegidas no Brasil e estabelece critérios e normas para sua criação, implantação e gestão.

Um dos objetivos do SNUC que merece destaque neste trabalho é "proteger as características relevantes de natureza geológica, geomorfológica, espeleológica, arqueológica, paleontológica e cultural" (Art. $4^{\circ}$, alínea VII) e "proteger e recuperar recursos hídricos e edáficos" (Art. $4^{\circ}$, alínea VIII) (Brasil, 2000). Nesse sentido, o enquadramento e proteção da geodiversidade são possíveis em algumas das categorias estabelecidas por esta lei, embora, na prática, a maior parte das UCs seja criada e gerida para a proteção da biodiversidade.

Em decorrência da diversidade de situações acerca do meio natural e social presente na realidade brasileira, o SNUC divide as UCs em dois grandes grupos: Proteção Integral e Uso Sustentável.

As Unidades de Proteção Integral têm como principal objetivo a preservação da natureza e não podem ser habitadas pelo homem. Somente é permitido o uso 
indireto dos recursos naturais em atividades como pesquisas científicas, turismo ecológico, educação e interpretação ambiental, entre outras. Estão inseridas nesse grupo as categorias: Estação Ecológica (EE), Reserva Biológica (REBIO), Parque Nacional (PARNA), Monumento Natural (MN) e Refugio de Vida Silvestre (RVS). (Brasil, 2000; ICMBIO, 2018).

As Unidades de Uso Sustentável têm como objetivo compatibilizar a conservação da natureza com o uso sustentável dos recursos naturais. Essas unidades permitem a presença de moradores e atividades que envolvem coleta e uso dos recursos, desde que se mantenha a integridade dos recursos ambientais renováveis. As categorias de UCs desse grupo são: Área de Relevante Interesse Ecológico (ARIE), Floresta Nacional (FLONA), Reserva de Fauna (REFAU), Reserva de Desenvolvimento Sustentável (RDS), Reserva Extrativista, Área de Proteção Ambiental (APA), e Reserva Particular do Patrimônio Natural (RPPN) (Brasil, 2000; ICMBIO, 2008).

Segundo Pereira et al. (2008), mesmo que os objetivos do SNUC especifiquem a possibilidade de proteção dos recursos abióticos, as leis estão centradas na biodiversidade, gerando um descaso com os recursos abióticos do meio natural. Os mesmos autores indicam as categorias compatíveis para enquadrar os locais de interesse geológico que são: Parque Nacional, Monumento Natural, Área de Proteção Ambiental, Área de Relevante Interesse Ecológico, Reserva Extrativista, Reserva de Desenvolvimento Sustentável e Reserva Particular do Patrimônio Natural. No entanto, para algumas categorias são necessárias adaptações que serão implementadas apenas quando forem praticadas.

A área de estudo insere-se no Mosaico de Áreas Protegidas do Lagamar, que abrange toda a região do Complexo Estuarino-lagunar Iguape, Cananeia e Paranaguá. As unidades de conservação da região são geridas por diferentes órgãos, federais (ICMBIO), estaduais (Fundação Florestal) e municipais (Prefeitura de Iguape), especificados na tabela 13, com seu tipo de uso e o órgão responsável pela unidade.

A tabela 14 apresenta o enquadramento legal dos sítios inventariados e 0 resultado do risco de degradação. A distribuição dos sítios inventariados nas UCs pode ser vista na Fig. 21. Observa-se que a maioria dos sítios classifica-se em baixo risco de degradação, com exceção dos sítios da categoria geológica Evolução Quaternária. Isso se deve ao fato de que, embora todos os sítios se localizem em 
áreas com proteção legal, alguns não possuem controle de acesso e são justamente os mais frágeis. Portanto, esses locais são prioridade e necessitam de estratégias que podem ser desenvolvidas e geridas com auxílio das UCs.

Tabela 13 - Relação de UCs nos municípios de Iguape e llha Comprida.

\begin{tabular}{|c|c|c|c|}
\hline Área Protegida & Município & Tipo de uso & Órgão gestor \\
\hline $\begin{array}{l}\text { Estação Ecológica Jureia- } \\
\text { Itatins }\end{array}$ & Iguape & $\begin{array}{l}\text { Proteção } \\
\text { Integral }\end{array}$ & Fundação Florestal \\
\hline $\begin{array}{c}\text { Parque Estadual do } \\
\text { Prelado }\end{array}$ & Iguape & $\begin{array}{l}\text { Proteção } \\
\text { Integral }\end{array}$ & Fundação Florestal \\
\hline $\begin{array}{c}\text { Parque Estadual do } \\
\text { Itinguçu }\end{array}$ & Iguape & $\begin{array}{l}\text { Proteção } \\
\text { Integral }\end{array}$ & Fundação Florestal \\
\hline $\begin{array}{l}\text { Estação Ecológica dos } \\
\text { Chauás }\end{array}$ & Iguape & $\begin{array}{l}\text { Proteção } \\
\text { Integral }\end{array}$ & Fundação Florestal \\
\hline$R D S$ do Despraiado & Iguape & $\begin{array}{c}\text { Uso } \\
\text { Sustentável }\end{array}$ & Fundação Florestal \\
\hline $\begin{array}{c}\text { APA Cananeia-lguape e } \\
\text { Peruibe }\end{array}$ & $\begin{array}{l}\text { Iguape e Ilha } \\
\text { Comprida }\end{array}$ & $\begin{array}{l}\text { Uso } \\
\text { Sustentável }\end{array}$ & $\begin{array}{l}\text { Instituto Chico Mendes } \\
\text { ICMBIO }\end{array}$ \\
\hline APA Marinha do Sul & $\begin{array}{l}\text { Iguape e llha } \\
\text { Comprida }\end{array}$ & $\begin{array}{c}\text { Uso } \\
\text { Sustentável }\end{array}$ & Fundação Florestal \\
\hline $\begin{array}{l}\text { Parque Municipal Morro do } \\
\text { Espia }\end{array}$ & Iguape & $\begin{array}{l}\text { Uso } \\
\text { Sustentável }\end{array}$ & $\begin{array}{c}\text { Prefeitura de Iguape/ APA Cananeia, } \\
\text { Iguape e Peruíbe }\end{array}$ \\
\hline APA Ilha Comprida & Ilha Comprida & $\begin{array}{l}\text { Uso } \\
\text { Sustentável }\end{array}$ & Fundação Florestal \\
\hline $\begin{array}{c}\text { Árie interesse Ecológico do } \\
\text { Guará }\end{array}$ & Ilha Comprida & $\begin{array}{c}\text { Uso } \\
\text { Sustentável }\end{array}$ & Fundação Florestal \\
\hline
\end{tabular}

Uma das formas mais diretas de incluir locais relevantes na gestão das UCs é por meio do plano de manejo, que é o principal instrumento utilizado na gestão destas unidades. De acordo com a Lei Federal no 9.985/2000, o Plano de Manejo é definido como "documento técnico mediante o qual, com fundamento nos objetivos gerais de uma UC, se estabelece o seu zoneamento e as normas que devem presidir o uso da área e o manejo dos recursos naturais, inclusive a implantação das estruturas físicas necessárias à gestão da unidade" (Brasil, 2000).

Dessa forma, os planos de manejos reúnem todo o conhecimento cientifico da UC a partir de estudos e diagnósticos dos elementos do meio físico (geologia, geomorfologia, clima, hidrologia e solos), biótico (fauna e flora) e social (uso e 
ocupação da terra, socioeconomia, visitação pública, patrimônio histórico-cultural, material e imaterial, bem como a situação fundiária) (SMA, 2014).

Tabela 14 - Enquadramento legal dos geossítios e sítio da geodiversidade e risco de degradação.

*Sítio da geodiversidade

\begin{tabular}{|c|c|c|c|c|}
\hline & Sítios & Enquadramento legal & $\begin{array}{l}\text { Unidade de } \\
\text { Conservação }\end{array}$ & $\begin{array}{c}\text { Risco de } \\
\text { degradação }\end{array}$ \\
\hline 1 & $\begin{array}{l}\text { Morro do } \\
\text { Espia }\end{array}$ & $\begin{array}{l}\text { APACIP/ Parque municipal do } \\
\text { Morro do Espia }\end{array}$ & Uso Sustentável & Baixo \\
\hline 2 & Maciço da Jureia & Estação Ecológica Jureia-Itatins & Proteção Integral & Baixo \\
\hline 3 & $\begin{array}{c}\text { Processos sedimentares } \\
\text { da desembocadura do rio } \\
\text { Ribeira de Iguape }\end{array}$ & APACIP/ APA Ilha Comprida & Uso Sustentável & Médio \\
\hline 4 & $\begin{array}{l}\text { Campo de dunas } \\
\text { ativas do Araçá }\end{array}$ & APA Ilha Comprida & Uso Sustentável & Alto \\
\hline 5 & $\begin{array}{c}\text { Dunas, paleodunas e } \\
\text { paleolagunas da Ilha } \\
\text { Comprida }\end{array}$ & APA Ilha Comprida & Uso Sustentável & Alto \\
\hline 6 & $\begin{array}{l}\text { Terraços holocênicos do } \\
\text { Pontal da Trincheira }\end{array}$ & APACIP & Uso Sustentável & Médio \\
\hline 7 & $\begin{array}{c}\text { Cordões litorâneos e } \\
\text { paleodunas da praia da } \\
\text { Jureia }\end{array}$ & APACIP & Uso Sustentável & Médio \\
\hline 8 & $\begin{array}{l}\text { Intrusão alcalina da Ilha } \\
\text { Comprida }\end{array}$ & APA Ilha Comprida & Uso Sustentável & Baixo \\
\hline 9 & $\begin{array}{l}\text { Granito Iguape com } \\
\text { feições miloníticas }\end{array}$ & APACIP & Uso Sustentável & Baixo \\
\hline 10 & $\begin{array}{l}\text { Granito Iguape no Morro } \\
\text { do Espia }\end{array}$ & APACIP & Uso Sustentável & Médio \\
\hline 11 & $\begin{array}{c}\text { Granulitos do Complexo } \\
\text { Itatins na Cachoeira do } \\
\text { Paraíso }\end{array}$ & $\begin{array}{c}\text { Parque Nacional do Itinguçu/ } \\
\text { E.E. Jureia - Itatins }\end{array}$ & Proteção Integral & Baixo \\
\hline 12 & $\begin{array}{c}\text { Paragnaisses da Praia da } \\
\text { Jureia }\end{array}$ & $\begin{array}{c}\text { Parque Nacional do Prelado/ } \\
\text { E.E. Jureia -Itatins }\end{array}$ & Proteção Integral & Baixo \\
\hline 13 & $\begin{array}{l}\text { Paragnaisses da } \\
\text { Cachoeira Grande* }\end{array}$ & Estação Ecológica Jureia-Itatins & Proteção Integral & Baixo \\
\hline
\end{tabular}




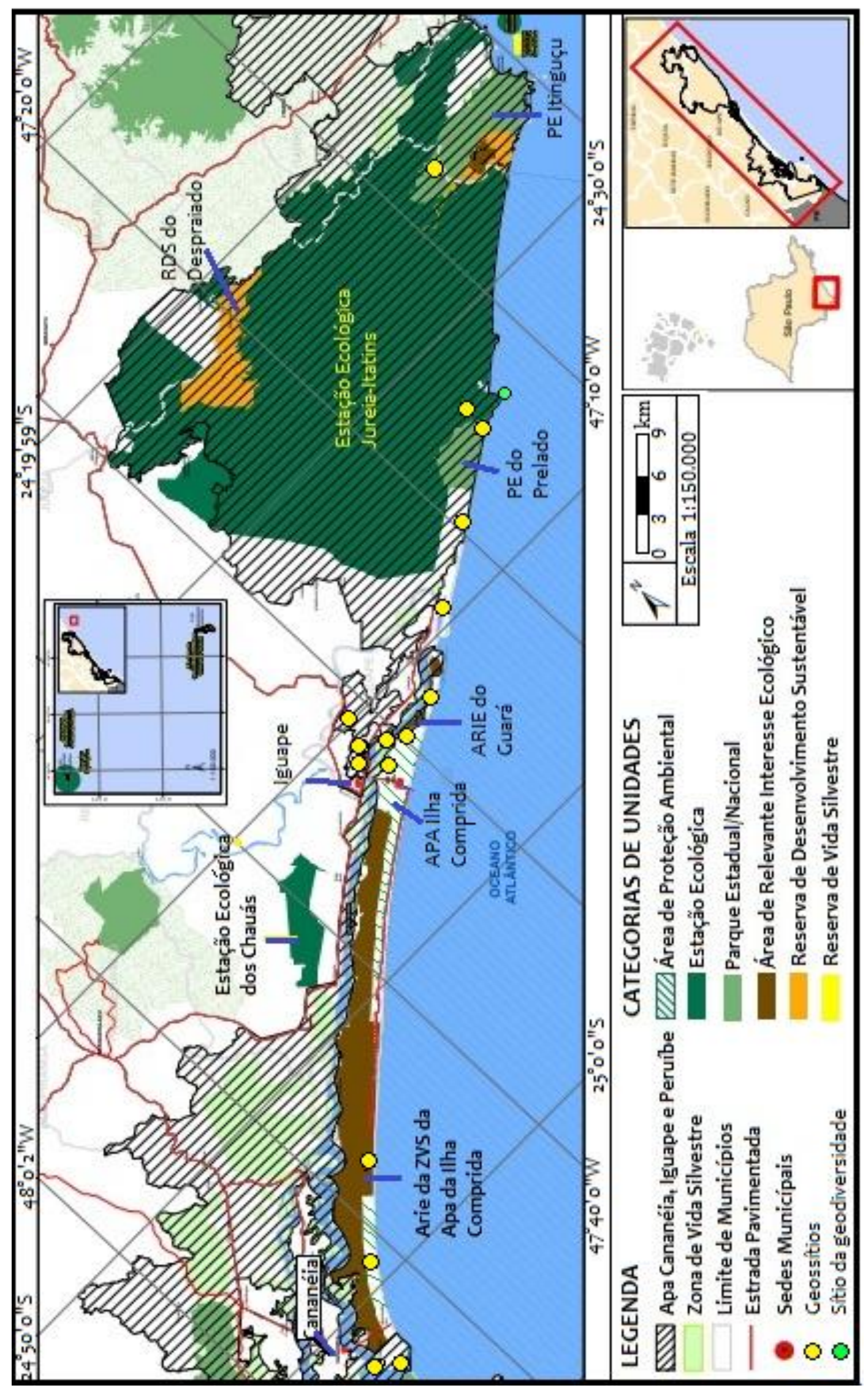

Figura 21 - Mapa do enquadramento legal dos municípios de Iguape e llha Comprida. Adaptado do plano de manejo da APACIP. 


\subsection{Integração dos dados e propostas de valorização e divulgação}

Neste capítulo os resultados obtidos na pesquisa serão utilizados para sugerir ações para o uso educativo e turístico e apresentar propostas de valorização e divulgação dos locais inventariados. As informações obtidas aqui podem contribuir para atividades que estão ou serão desenvolvidas nas UCs.

\subsubsection{Propostas para a APA Cananeia Iguape e Peruíbe (APACIP)}

A APACIP é uma unidade de uso sustentável, cuja fiscalização é dificultada por ser uma grande área com diversas UCs incluídas e propriedades particulares. Todos os geossítios presentes nesse inventário estão situados na APACIP e estão sobrepostos com outras UCs. Os geossítios que possuem somente a APACIP como área protegida são os geossítios Granito Iguape com feições miloniticas, Granito Iguape no Morro do Espia e parte do geossítio Cordões litorâneos e paleodunas da praia da Jureia.

O geossítio Granito Iguape com feições miloníticas não possui potencial educativo, pois suas estruturas estão alteradas e de difícil observação. Além disso, não possui potencial turístico também, já que se encontra dentro de uma residência.

O geossítio Granito Iguape no Morro do Espia está localizado numa propriedade particular que proporciona lazer e turismo aos visitantes. Esse local seria adequado para divulgar esse granito que leva o nome da cidade, e que seu corpo rochoso, o Morro, já foi uma antiga ilha. Isso poderia ser feito através de painel ou folhetos dispostos na área de lazer.

O geossítio Cordões Litorâneos e paleodunas da praia da Jureia possui parte no PE do Prelado a nordeste e Parte na APACIP na parte sudoeste. Sugerem-se painéis interpretativos colocados nas proximidades do Bairro da Ribeira com 0 objetivo de alertar as pessoas sobre a fragilidade das dunas principalmente quando se é retirada sua vegetação e quais as consequências que isso implica.

Para os demais geossítios da APACIP foi proposto um roteiro ciclogeoturístico que será descrito no item 6.3.2. 


\subsubsection{Propostas para a Estação Ecológica Jureia-Itatins (EEJI)}

A EEJI abrange um mosaico de diversos tipos de unidades de conservação inseridas em diversos municípios. Alguns locais, como o Maciço da Jureia e o sítio da Geodiversidade Paragnaisse da Cachoeira Grande, estão integralmente dentro da EEJI. Outros geossítios estão em áreas sobrepostas por outras UCs, tais como o geossítio Granulitos do Complexo Itatins na Cachoeira do Paraíso, que também faz parte do Parque Estadual do Itinguçu e o geossítio Paragnaisses da praia da Jureia, pertencente também ao Parque Estadual do Prelado.

Como mencionado em Somekawa e Garcia (2017), a EEJI teve sua criação associada a grandes ameaças que estavam ocorrendo na região. A especulação imobiliária e a possível construção de um condomínio e de uma usina nuclear foram ameaças que fizeram com que movimentos ambientalistas pressionassem as autoridades para que houvesse a suspensão da construção do empreendimento e a criação de uma Estação Ecológica. Em 1986, o Governo do Estado estabeleceu definitivamente a criação da EEJI, tendo como objetivo garantir a preservação da área (Câmara, 2009).

Entretanto, a implementação dessa UC não reduziu os conflitos nessa região, pois a EEJI é uma unidade de proteção integral e por toda a área situam-se comunidades caiçaras que já viviam ali antes da sua criação, o que é contraditório, visto que há divergências sobre a ideia de conservação da natureza e o papel das áreas protegidas dentro das UCs. Nesse sentido, foi criado o mosaico de UCs, com o objetivo de adequar a legislação à situação em que se encontrava a área da EEJI.

Nessa perspectiva serão sugeridas algumas propostas de gestão para os sítios geológicos situados nesta UC, visando sua valorização e divulgação.

O geossítio Granulitos do Complexo Itatins na Cachoeira Grande também faz parte do Parque Estadual do Itinguçu. Recomenda-se para esse local um painel informativo no centro de visitantes, esse painel pode ser utilizado pelos monitores que fazem a recepção aos visitantes e informações sobre a geodiversidade local podem ser mencionadas com o objetivo de divulgar as rochas ali presentes.

O geossítio Paragnaisses da Praia da Jureia tem acesso por Iguape sentido bairro Barra do Ribeira. Apesar de estar em duas UCs não há limite de acesso e é frequentemente acessados por veículos pela praia. Possui potencial educativo para alunos de ensino superior, as feições geológicas desse sítio foram intensamente afetadas pelo Ciclo Brasiliano e para compreender é necessário ter bons 
conhecimentos de geologia; portanto podem ser utilizado em aulas de campo. Esse geossítio também tem grande potencial turístico, pois se situa no costão rochoso da praia da Jureia, um dos atrativos do município, além de estar incluído na rota cicloturistica Lagamar, proposta por Romão et al. (2018).

O Maciço da Juréia, de interesse geomorfológico, tem potencial educativo, pois ajuda a compreender $\mathrm{o}$ processo de formação da paisagem, podendo ser utilizado em visitas de campo por escolas ou universidades. O maciço possui beleza cênica e a praia da Jureia é um dos locais de melhor observação desse geossítio. Por ser uma unidade de proteção integral, seu uso é limitado e somente autorizado para atividades educativas, de pesquisa e de ecoturismo. Além disso, no maciço as visitas devem ser feitas mediante agendamento prévio e acompanhamento de guia local, O percurso que pode ser feito é através da trilha do Imperador, que tem início ao lado do núcleo administrativo do PE do Prelado, a poucos metros do costão da Jureia, até a praia do Rio Verde. Essa trilha possui interesses histórico, cultural e ecológico e o trecho que passa pelo maciço conta ainda com duas cachoeiras, sendo uma delas sítio da geodiversidade.

O sítio da geodiversidade Paragnaisses da Cachoeira Grande está localizado no Maciço da Jureia e possui potencial educativo, pois as rochas colaboram para 0 entendimento da abertura do Oceano Atlântico Sul, assunto que pode ser abordado pelos monitores que acompanham as visitas.

Diante da estrutura que a EEJl apresenta recomenda-se um curso de capacitação para os monitores ambientais dessa unidade, visto que, com exceção do geossítio Paragnaisses da Jureia, todos os outros necessitam de acompanhamento ou instrução de guia. Assim, os elementos geológicos desses locais podem ser mencionados durante as visitas, divulgando e integrando a geodiversidade numa visão mais interdisciplinar da natureza.

Outra colaboração que esse inventário pode fazer é na atividade "Trilha das Mudanças Climáticas Globais", desenvolvida na EEJI pelo Instituto de Biociências da USP, com apoio do projeto Ecossistemas Costeiros. A trilha tem o objetivo de capacitar alunos e professores da rede de escolas estaduais a compreender as relações que envolvem as mudanças climáticas. O geossítio Maciço da Jureia pode colaborar na compreensão das mudanças climáticas, visto que foi incorporado ao continente por processos sedimentares trazidos principalmente por erosão da Serra do Mar durante os períodos de avanço e recuo do nível relativo do mar. 


\subsubsection{Propostas para a APA Ilha Comprida (APAIC)}

A APAIC é uma unidade de uso sustentável implantada em 1987, antes da ilha ser emancipada. Sua criação se justifica pelo rico complexo de ecossistemas preservados que ainda restam no litoral brasileiro.

Após a sua emancipação até os dias de hoje a APAIC sofre intensa ocupação imobiliária, muitas irregulares, o que coloca em risco muitos geossítios. Outro fator que afeta os geossítios de APA é o turismo de massa, principalmente na temporada.

$\mathrm{Na}$ APAIC estão inseridos os geossítios Terraços holocênicos do Pontal da Trincheira, Intrusão alcalina da llha Comprida, Dunas, paleodunas e paleolagunas da Ilha Comprida, Campo de Dunas do Araçá e Processos sedimentares da desembocadura do rio Ribeira.

Esses geossítios possuem potencial educativo pois ajudam a compreender as fases de evolução da ilha. Neste trabalho, uma proposta de roteiro geoturistico foi criada a fim de contar a história de formação da ilha e será descrita no item 6.3.1.

As dunas e paleodunas da llha Comprida, por serem as mais representativas do estado, necessitam de melhor planejamento para conservar suas feições geológicas, pois a situação em que se encontram é bem complexa e envolve áreas protegidas e particulares. A recomendação inicial seria limitar o acesso a veículos em algumas regiões, como no Campo de Dunas do Araçá (que também é uma ARIE) e nas dunas do Juruvaúna, que são os exemplos mais preservados.

A intrusão alcalina da llha Comprida não possui grande beleza cênica, mas sua feição é relacionada ao morro de São João e, da balsa que interliga os municípios de Cananeia e llha Comprida, é possível observar as duas feições geomorfológicas. Nesse local seria interessante um painel explicando a formação dessas duas intrusões e ilustrando os processos magmáticos formadores dessas rochas. Esse sítio pode ainda ser utilizado para estudos de campo voltados para ensino fundamental II, médio e ensino superior.

Os geossítios referente à CG Evolução Quaternária têm sua gestão dificultada devido à sua fragilidade e à grande extensão. Além disso, não há fiscalização ao longo da praia. Apesar de estar em duas APAs e uma ARIE, a ilha não tem limite de acesso, inclusive por veículos na praia e por cima das dunas. Sugere-se que essas atividades sejam controladas ou até mesmo banidas, visto o alto risco de degradação que ocorrem nesses locais. 
Outra sugestão educativa seria integrar esses geossítios ao projeto EcoSurf, uma ONG que atua em atividades de Surf e Educação Ambiental na llha. Essas atividades envolvem moradores e turistas em ações em prol do meio ambiente e introduzir informações sobre a importância dos geossítios para o equilíbrio ambiental da ilha é uma forma de valorizar e divulgar esses locais para moradores e turistas.

No geossítio Processos sedimentares da desembocadura do Icapara poderia haver um painel no centro de visitantes ou até mesmo em uma praça de grande movimentação no centro da cidade, informando o porquê de existir tantos casos de erosão na praia. Através desse geossítio é possível mostrar que aquela região é relativamente recente e foi consequência da abertura do canal Vale Grande e que construções naquela área correm riscos de sofrer com a erosão.

\subsection{Propostas de roteiros geoturísticos}

A maior parte dos locais de interesse geológico inventariados em Iguape e Ilha Comprida possuem, para além do valor científico, alto potencial educativo e turístico. O potencial turístico se justifica pelo fato de, em geral, serem locais que já recebem muitos turistas durante todo 0 ano. O potencial educativo, por sua vez, concentra-se no contexto de processos da dinâmica externa, especialmente a costeira, facilmente observados ao longo da área de estudo. Estes fatos contribuem para que a geodiversidade e o patrimônio geológico da região constituam ferramentas poderosas na disseminação do conhecimento geocientífico e na educação ambiental como instrumento de proteção do meio natural.

Neste sentido, foram desenvolvidas duas propostas de roteiros geoturísticos que visam, além de colaborar na disseminação de conteúdos para o público geral, aumentar a percepção das pessoas em relação ao espaço onde vivem.

O Roteiro 1, desenvolvido integralmente no contexto da área abordada nesta pesquisa, apresenta a história de formação da llha Comprida contada através dos sítios geológicos. O Roteiro 2 abrange os municípios de Iguape, llha Comprida e Cananeia e vem sendo desenvolvido na região do Lagamar Paulista (Romão et al. 2018). Embora os pontos do Roteiro 1 estejam incluídos no Roteiro 2, a abordagem é feita de forma distinta, o que justifica a apresentação dos dois roteiros. 
Apresenta-se, aqui, a proposta de conteúdo dos roteiros, que estão em fase de desenvolvimento.

\subsubsection{Roteiro 1 - Como se formou a Ilha Comprida?}

O município de llha Comprida é a barreira arenosa mais extensa do litoral paulista, formada durante o Quaternário e com cerca de $74 \mathrm{~km}$ de comprimento e até $5 \mathrm{~km}$ de largura. Os geossítios inventariados no município de llha Comprida constituem registros da evolução geológica da llha e estão localizados ao longo de toda ilha.

Este roteiro foi idealizado para ser realizado tanto a pé, quanto de bicicleta para grupo de todas as idades. Ao longo do percurso existem restaurantes, hotéis, pousadas, sinal de telefone e acesso a carros, porém são mais concentrados no Boqueirão Norte e Sul e proximas às comunidades de Pedrinhas e Juruvaúna. Sugere-se que o inicio da rota seja no Boqueirão Sul, local onde se iniciou a formação da ilha.

A formação dessa barreira arenosa decorre de cinco fases de evolução descritas por Suguio e Martin (1978) e, mais tarde, Guedes (2009), que propôs o modelo evolutivo que será utilizado nessa proposta. Segundo o autor da proposta, as seguintes etapas estão envolvidas nesta história:

6000 anos A.P. Fase 1 - Corresponde a formação da ilha.

De 6000 a 5000 anos A.P. - Fase 2 - Crescimento acelerado em torno de 10,2 a 22,8 m/ano longitudinal e 2,6 m/ano transversal. - formação de cordões de origem praial.

De 5000 a 2000 A.P. - Fase 3 - Crescimento longitudinal baixo 5,2 a 6,9 $\mathrm{m} /$ ano e transversal caiu a praticamente zero.

De 2000 a 200 anos A.P. - Fase 4 - Bloqueio do crescimento longitudinal pelo Morro do Icapara, o que forçou o crescimento transversal até $0,5 \mathrm{~m} / \mathrm{ano}$ em grande parte ao longo da ilha. Durante essa fase predominou, a adição de cristas praiais antes da Pequena Idade do Gelo (1450 a 1850 d.c), e de formação de cordões de dunas frontais após esse período.

De 200 A. P até o presente - Fase 5 - após superar o bloqueio longitudinal imposto pelo Morro do Espia a ilha retomou o crescimento longitudinal, acelerado após a abertura do Valo Grande. Nesse período além do crescimento na parte nordeste houve erosão na região centro-sul da ilha. 
Com base nesta história evolutiva, os geossítios inventariados no municipio de Ilha Comprida foram utilizados, neste roteiro, para representar estes eventos, ajudando a compreender essa evolução e buscando a conscientização sobre possíveis ameaças à geodiversidade e ao patrimônio geológico do município.

A figura 20 apresenta o mapa dos pontos do roteiro e a tabela 15 apresenta a relação das fases de evolução da ilha com os geossítios.

Tabela 15 - Associação das fases de formação da ilha com os geossítios e suas principais características.

\begin{tabular}{|c|c|c|c|c|}
\hline $\begin{array}{l}\text { Marcos } \\
\text { cronoló } \\
\text { gicos }\end{array}$ & $\begin{array}{l}\text { Fases de } \\
\text { evolução }\end{array}$ & Pontos & $\begin{array}{l}\text { Geossítios } \\
\text { associados }\end{array}$ & Principais características \\
\hline \multirow{2}{*}{$\begin{array}{l}6.000 \\
\text { A.P. }\end{array}$} & Fase 1 & 1 & $\begin{array}{l}\text { Intrusão alcalina da llha } \\
\text { Comprida }\end{array}$ & $\begin{array}{l}\text { Inicio da sedimentação da ilha partir dessa } \\
\text { intrusão alcalina. }\end{array}$ \\
\hline & & 2 & $\begin{array}{l}\text { Terraços holocênicos do } \\
\text { Pontal da Trincheira }\end{array}$ & Primeiros terraços a serem formados. \\
\hline $\begin{array}{l}5.000 \\
\text { A.P. }\end{array}$ & Fase 2 & 3 e 4 & $\begin{array}{l}\text { Dunas, paleodunas e } \\
\text { paleolagunas da llha } \\
\text { Comprida }\end{array}$ & $\begin{array}{l}\text { Crescimento tanto longitudinal quanto } \\
\text { transversal formando os primeiros cordões } \\
\text { litorâneos }\end{array}$ \\
\hline \multirow[t]{2}{*}{$\begin{array}{l}2.000 \\
\text { A.P }\end{array}$} & $\begin{array}{l}\text { Fases } \\
1,2 \text { e } 3\end{array}$ & 3 & Paleodunas & $\begin{array}{l}\text { Antigas dunas que representam antiga linha de } \\
\text { costa hoje encontram-se estabilizadas por } \\
\text { conta da vegetação. } \\
550 \text { a } 200 \text { anos A.P mudanças climáticas } \\
\text { relacionadas à Pequena Idade do Gelo } \\
\text { favoreceram a erosão e a estabilidade da linha } \\
\text { de costa formando, rupturas de deflação. }\end{array}$ \\
\hline & & 4 e 7 & Paleolagunas & Representação de antigo sistema lagunar \\
\hline \multirow{2}{*}{$\begin{array}{l}1.900 \\
\text { A.P. }\end{array}$} & $\begin{array}{l}\text { Fases } \\
3,4 \text { e } 5\end{array}$ & 3 e 5 & Dunas & Presença de dunas frontais ao longo da ilha, \\
\hline & $\begin{array}{l}\text { Fases } \\
4 \text { e } 5\end{array}$ & 5 & $\begin{array}{l}\text { Campo de dunas } \\
\text { ativas do Araçá }\end{array}$ & $\begin{array}{l}\text { Acumulo excessivo de areia em atividade, } \\
\text { indicação de antiga extremidade da ilha }\end{array}$ \\
\hline $\begin{array}{l}200 \\
\text { A.P. }\end{array}$ & Fase 5 & 7 e 8 & $\begin{array}{l}\text { Processos sedimentares } \\
\text { da desembocadura do } \\
\text { rio Ribeira de Iguape }\end{array}$ & $\begin{array}{l}\text { Crescimento da ilha, assoreamento do rio, } \\
\text { formação de ilhas, aumento do fluxo do rio, } \\
\text { erosão na parte nordeste da ilha }\end{array}$ \\
\hline
\end{tabular}




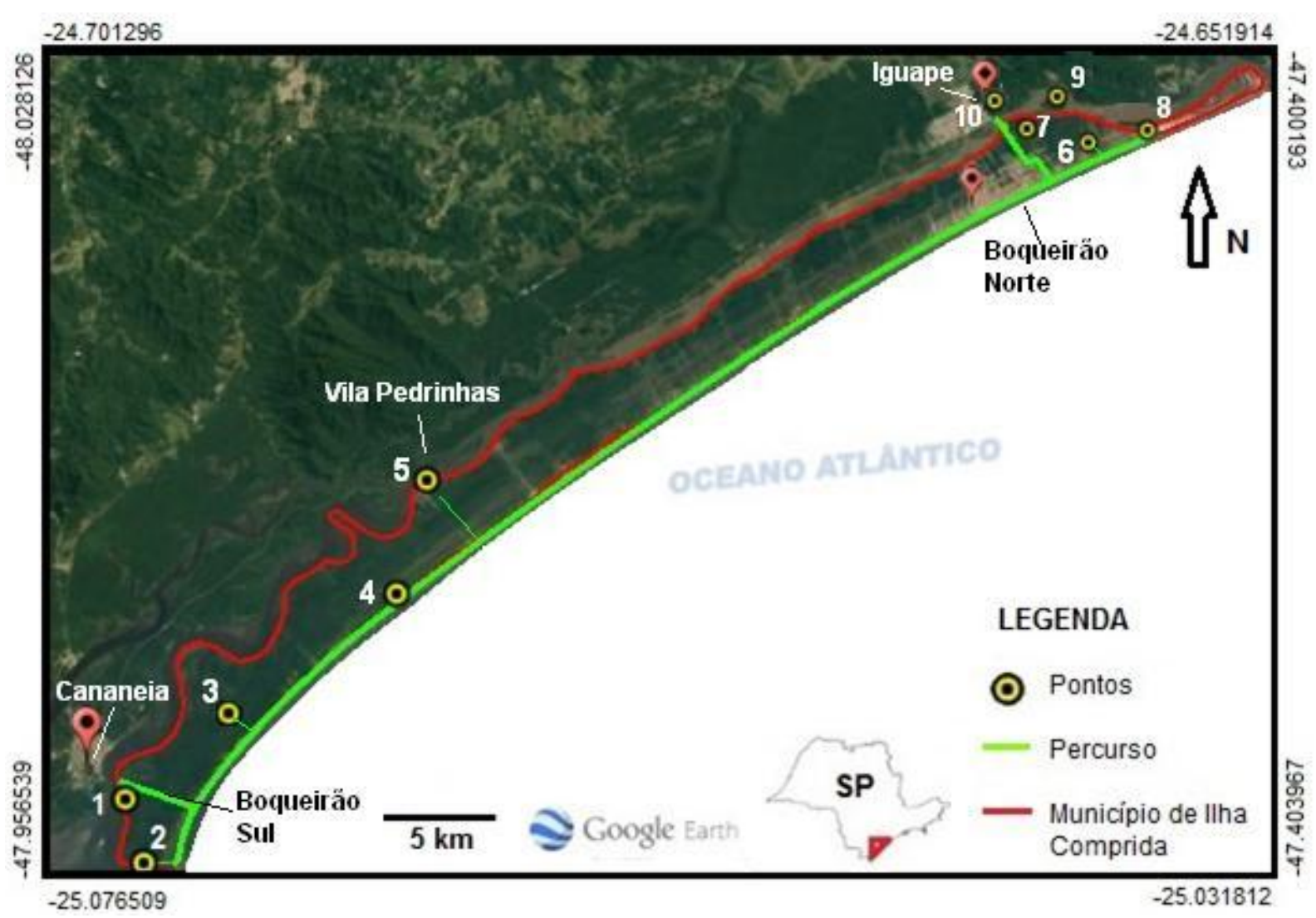

Figura 22 - Mapa de pontos do roteiro como se formou a llha Comprida?; 1) Intrusão alcalina da Ilha Comprida; 2) Terraços holocênicos do Pontal da Trincheira; 3) Paleodunas; 4) Dunas e Paleodunas do Juruvauna Paleolaguna; 5) Paleolagunas; 6) Paleodunas em área urbanizada; 7) Paleolagunas afetadas pelo Valo Grande; 8) Campo de Dunas ativas do Áraça; 9) Ilhas formadas pelos Processos sedimentares do rio Ribeira de Iguape.10) Local de observação do geossítio Processos

\section{De 6000 a 2000 A.P.}

Ponto 1 - Geossíto Intrusão alcalina da llha Comprida - Representa o precursor da formação da llha Comprida, a partir do qual sedimentos trazidos pelo rio formaram o início da barreira através da deriva litorânea longitudinal (Fig. 21A).

Ponto 2 - Geossítio Terraços holocênicos do Pontal da Trincheira Representa uma das porções sedimentares mais antigas da ilha presente no pontal da Trincheira, extremo sudoeste (Fig. 21B). Essa região sofre intensa erosão vinda da baia de Trepandé e com o turismo (Fig. 21C). É possivel observar camadas de sedimento de diferentes épocas, as mais inferiores contendo fosséis do artrópodo 
Callichirus Major (Fig. 21 D), que viviam em profundidade, fato que comprova a mudança do nível relativo do mar.

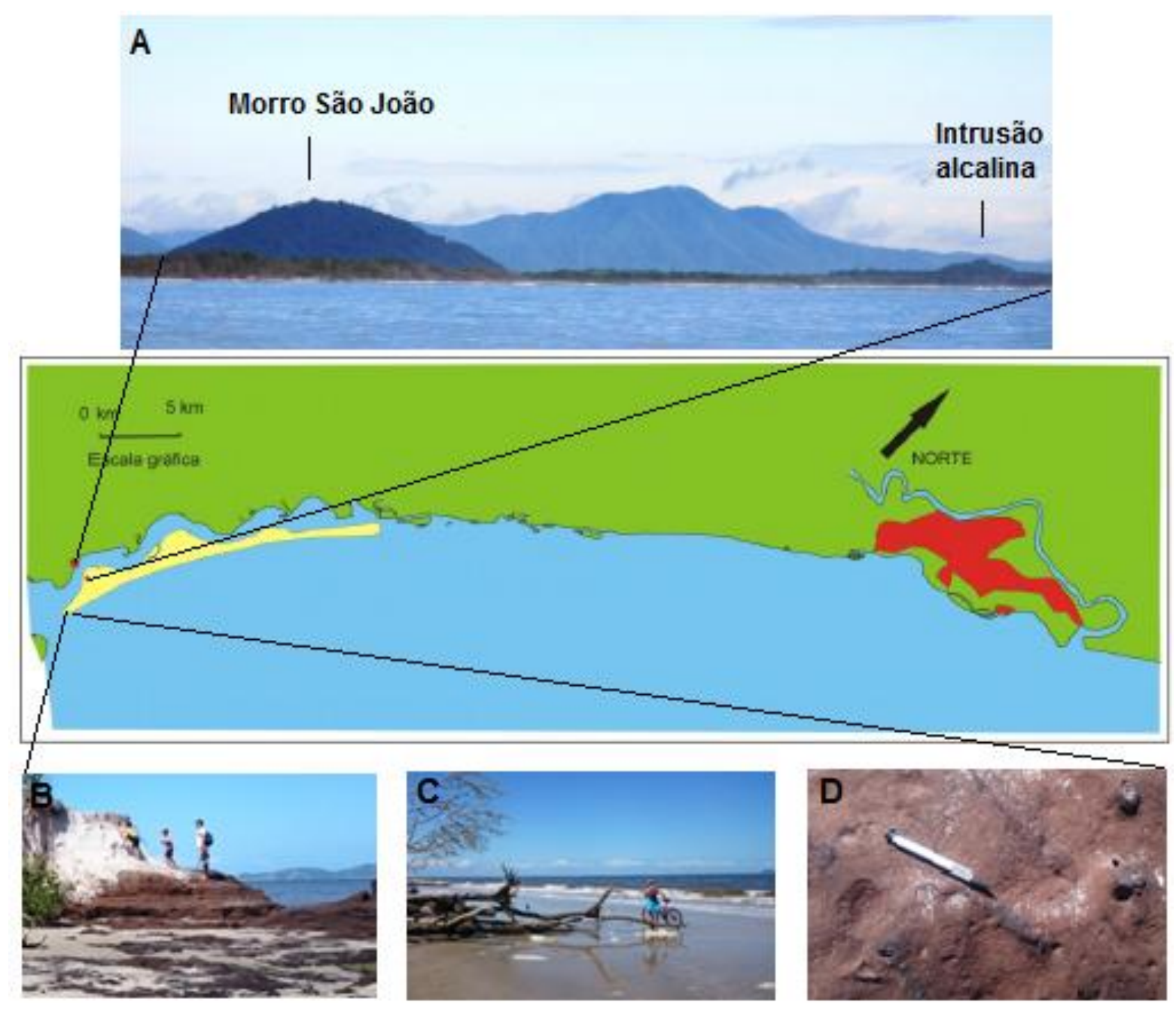

Figura 23 - Fase 1 de evolução da llha Comprida; A) Intrusão Alcalina em Cananeia e Ilha Comprida. B) Terraços sofrendo com ações antrópicas; C) Derrubada de árvores caracterizando intensa erosão nesse trecho; D) Presença de icnofósseis Callichirus Major, evidência de mudança no nível do mar. Adaptado de Guedes (2009).

Ponto 3 - Paleodunas - Representam antigas dunas de origem praial que hoje encontram-se estabilizadas por conta da vegetação, localizavam-se na linha da costa, indicios de crescimento transversal (Fig.22 A;B)

Ponto 4 - De 550 a 200 anos A.P mudanças climáticas relacionadas à Pequena Idade do Gelo favoreceram a erosão e a estabilidade da linha de costa, formando rupturas de deflação devido à erosão, a vegetação foi retirada e em alguns 
locais existe retrabalhamento da areia. Essas paleodunas estão presentes em várias porções da ilha, porém essas são as mais representativas (Fig.22 C;D).

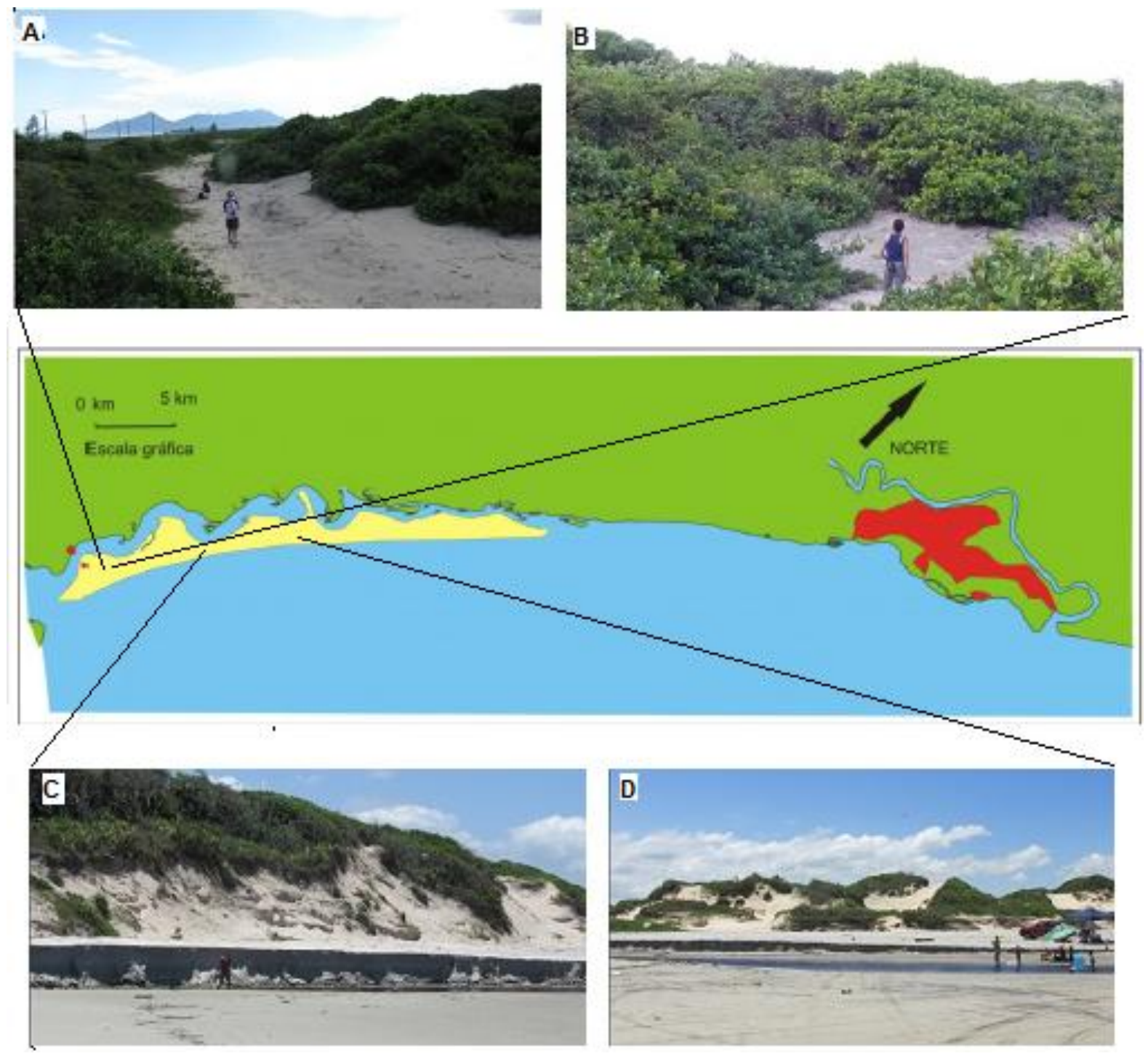

Figura 24 - Fase 2 de evolução da llha Comprida; A e B) Paleodunas densamente vegetadas, localizam-se mais ao interior cerca de 500 metros da linha de costa atual; C) Paleodunas com rupturas de deflação, ocasionadas pela retirada da vegetação, essas se encontram na linha de costa. Adaptado de Guedes (2009).

Ponto 5 - Os alinhamentos interiores, as paleolagunas, representam antigo sistema lagunar, hoje abriga região de mangue (Fig $23 \mathrm{~A} ; \mathrm{B}$ ).

Ponto 6 - Neste ponto concentram-se paleodunas atingidas pela especulação imobiliária, localizam-se a cerca de 1000 metros da praia, na parte mais urbanizada no Boqueirão Norte. (Fig. 23 C;D). 


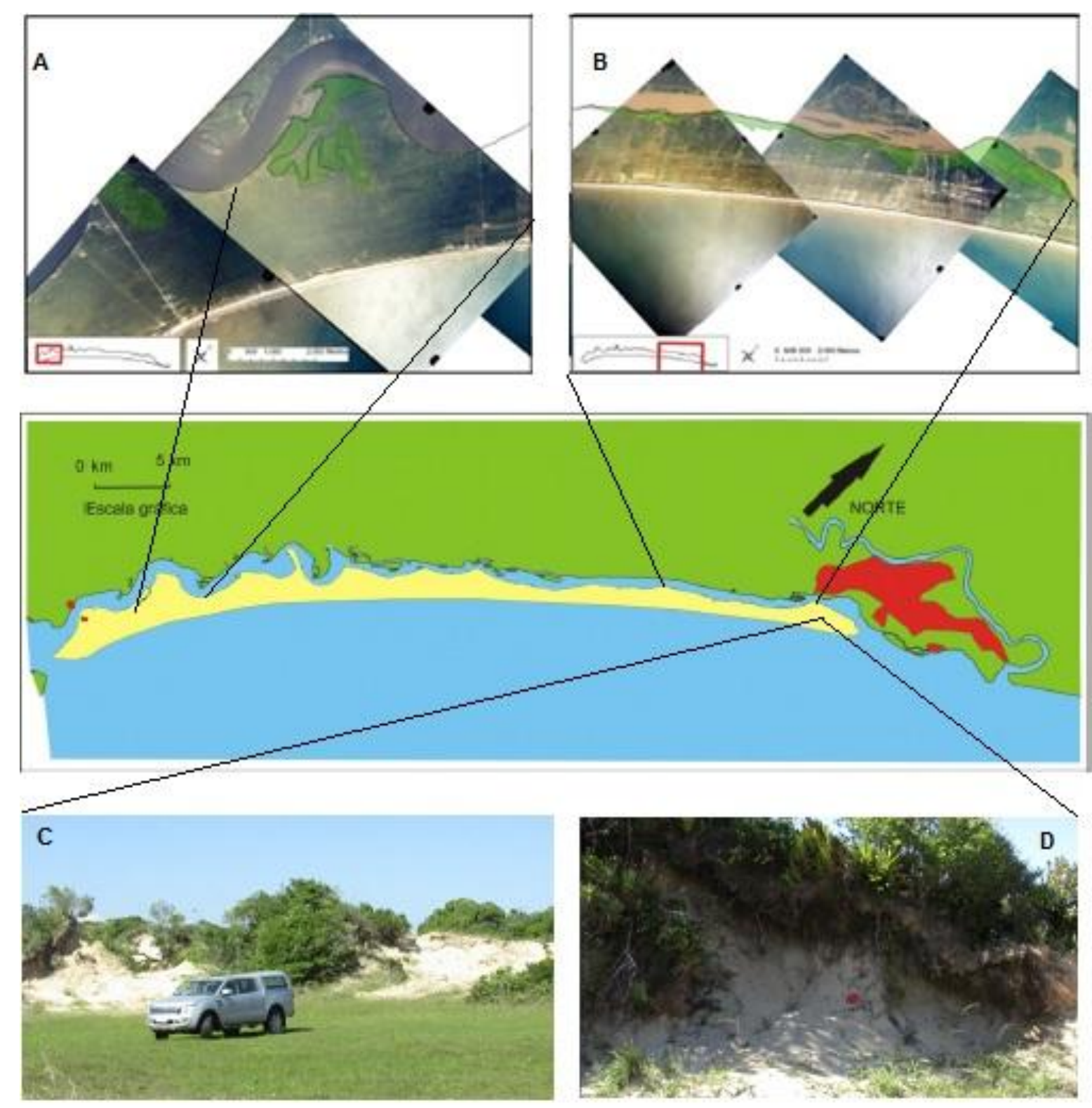

Figura 25 - Fase 4 de evolução da llha Comprida: A e B) Paleolagunas, formadas na fase 1; C e D) Paleodunas em área intensamente urbanizada. Adaptado de Guedes (2009).

\section{De 1900 até o presente}

Ponto 7 - Nesse ponto é possível observar as paleolagunas da ponte que liga Iguape a llha Comprida. Esse geossítio sofreu erosão com a abertura do Valo Grande, e é de boa visualização também para o geossítio Processos sedimentares da desembocadura do rio Ribeira de Iguape. 
Ponto 8 - O geossítio "Campo de dunas ativas do Araçá" representa a extremidade da ilha nesse periodo de 1900, onde houve também formação das dunas frontais e crescimento horizontal da ilha, o "momento de engorda" (Fig. 24 $A ; B)$.

Ponto 9 - llhas formadas pelo excesso de sedimentos dispostos pela abertura do Valo Grande. Do final desse periodo até atualmente, dois fatores principais influenciaram o crescimento da ilha (Fig. 24E). O primeiro foi a abertura do Valo Grande, em 1852, que deu fim ao bloqueio de crescimento longitudinal, fazendo com que a ilha passasse a crescer em uma taxa relativamente alta média de 25 a $30 \mathrm{~m} / \mathrm{ano}$. Esse fator pode ser representado pelo geossítio "Processos sedimentares da desembocadura do rio Ribeira de Iguape". O segundo fator foram as condições climáticas que permaneceram intensas após a Pequena Idade do Gelo, fato que se comprova com a formação de dunas frontais.

Ponto 10 - Esse ponto localiza-se no mirante do Cristo, no Morro do Espia. Dele é possível observar alguns aspectos associado ao geossítio Processos sedimentares da desembocadura do rio Ribeira de Iguape como a proprio canal, as ilhas, e parte da llha Comprida onde localiza-se as paleolagunas (ponto 7). 

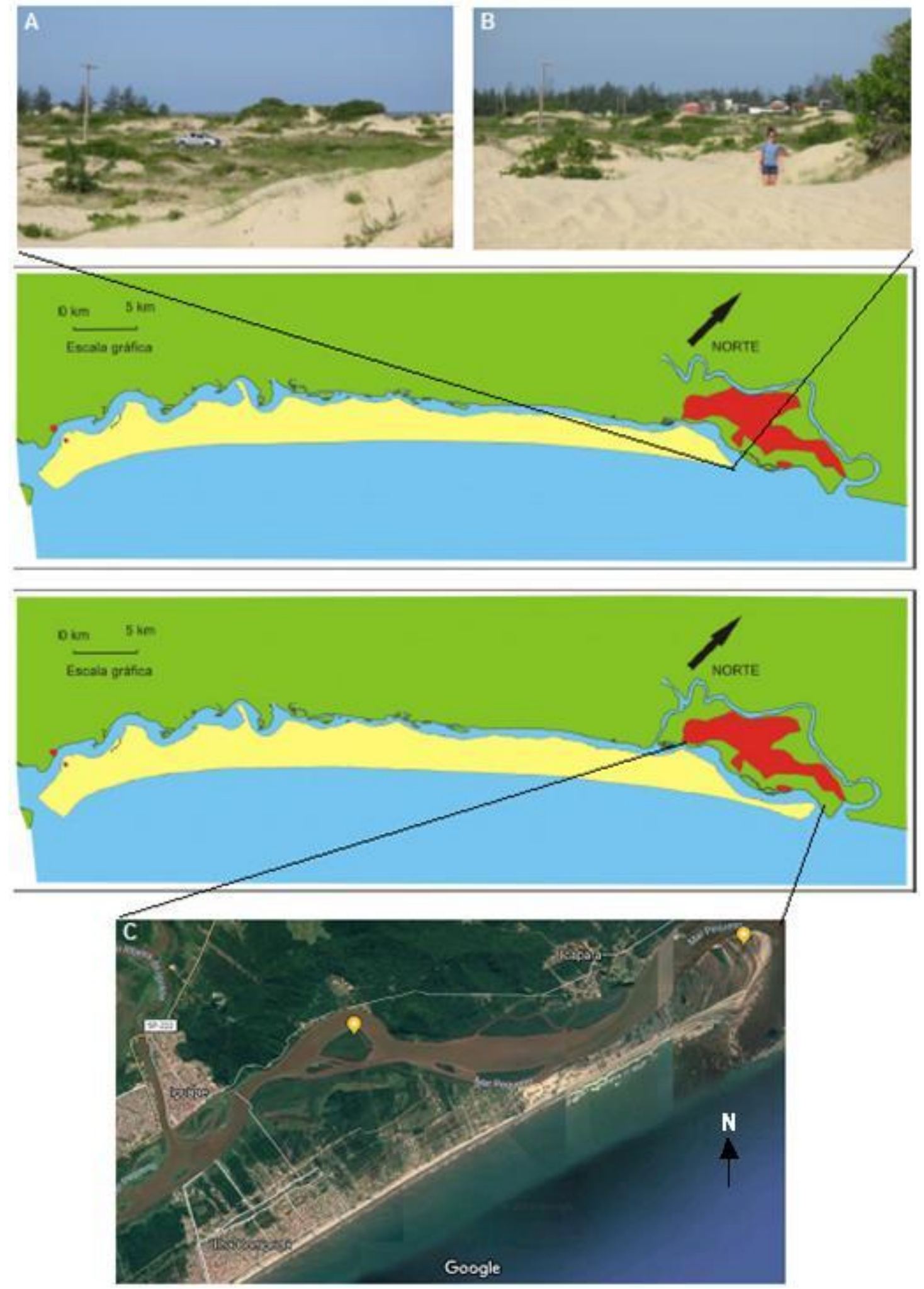

Figura 26 - Fase 5 de evolução da llha Comprida: A e B) Campo de dunas ativas do Araçá, evidencia de extremidade da ilha antes da abertura do Valo Grande; C) Processos sedimentares da desembocadura do rio Ribeira de Iguape, Pontos assinalados correspondem a ilha e crescimento da ilha decorrentes do alto fluxo de sedimentos. Adaptado Guedes (2009). 


\subsubsection{Proposta 2 - Roteiro cicloturístico do Lagamar Paulista}

Essa rota é um trabalho que está sendo elaborado por membros do NAP GeoHereditas $^{2}$, com base em inventários na região do litoral sul paulista (Romão et al. 2018). O município de Cananeia foi foco do trabalho de Romão (2017) e os municípios de Iguape e llha Comprida, deste trabalho.

O Circuito Lagamar São Paulo de Cicloturismo, como é chamado oficialmente, abrange os municípios de Iguape, llha Comprida, Cananeia, Jacupiranga e Pariquera-Açu e possui $126 \mathrm{~km}$ de extensão. A ideia deste roteiro é aproveitar a parte desse circuito que passa pelos locais de interesse geológico inventariados nos municípios de Iguape, Ilha Comprida e Cananeia e, ao mesmo tempo, incluir sítios geológicos que não estão no roteiro, mas que possuem potencial turístico e educativo.

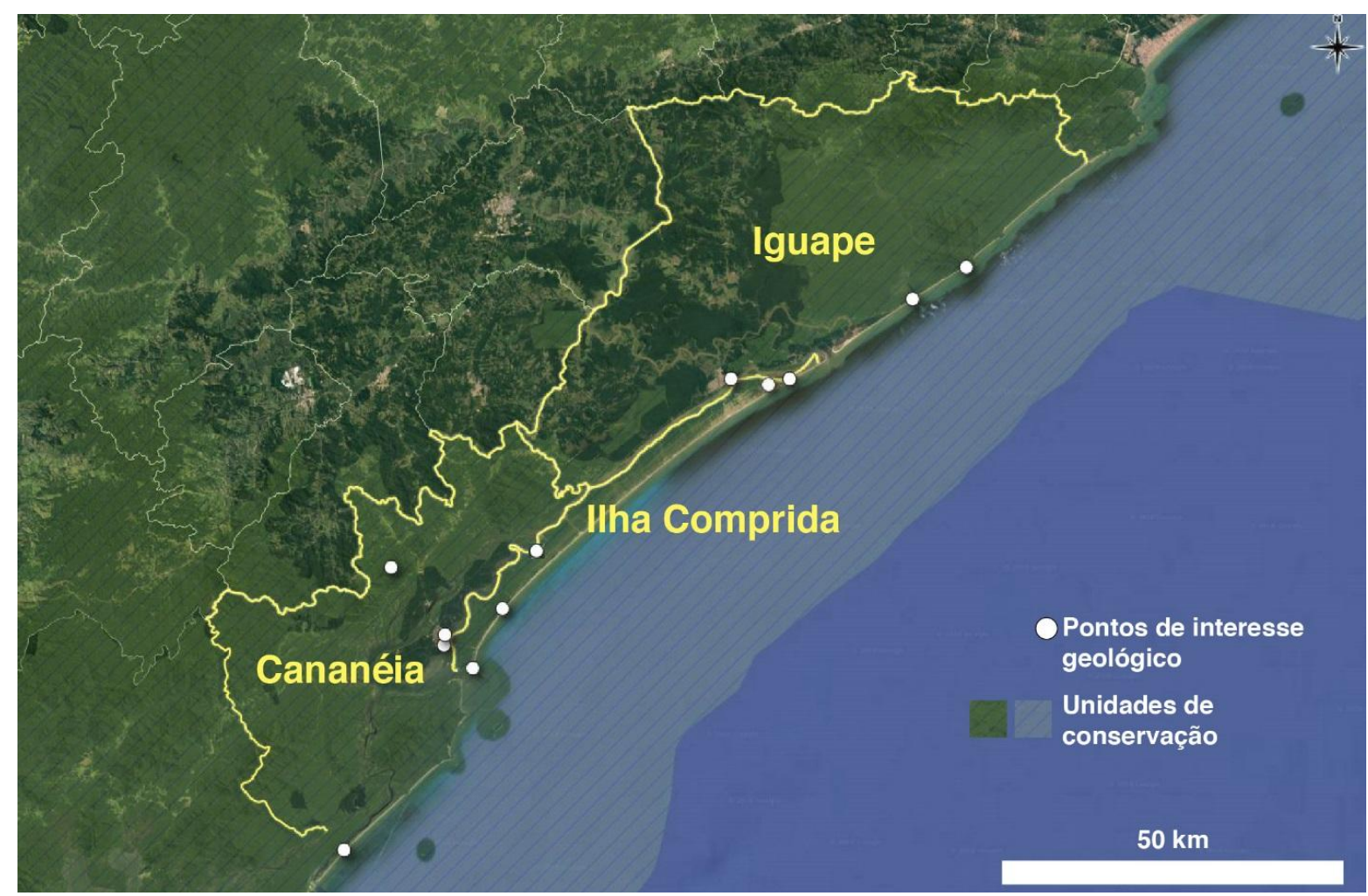

Figura 27 - Mapa de localização e de pontos do roteiro cicloturístico do Lagamar Paulista.

O percurso proposto possui duas opções: a primeira com extensão total de $150 \mathrm{~km}$ (4 dias) e a segunda, com $196 \mathrm{~km}$ (5 dias). Por todo o percurso existem restaurantes, hotéis, sinal de telefone e o acesso a carros.

\footnotetext{
${ }^{2}$ Núcleo de Apoio à Pesquisa em Patrimônio Geológico e Geoturismo
} 
A rota conta com 11 pontos de parada, que possuem, além da relevância cientifica, potencial para uso educativo e turístico (Tabela 16). Os locais selecionados representam registros da história geológica da região que vão desde o Neoproterozoico ao Cenozoico, passando por diversos ecossistemas e tipos de vegetação. Ao longo do percurso é possível observar as características geomorfológicas da região, bem como compreender alguns eventos e processos geológicos significativos para a composição da paisagem, como intrusões alcalinas e básicas, variações do nível relativo do mar e processos atuais da dinâmica costeira.

Embora o foco principal da rota seja os aspectos geológicos, o objetivo foi torná-la o mais interdisciplinar possível, acrescentando também informações sobre os aspectos biológicos, ambientais, sociais, arqueológicos, culturais e históricos.

Tabela 16 - Locais de interesse geológico incluídos no Roteiro Cicloturistico do Lagamar Paulista

\begin{tabular}{|c|c|c|c|c|}
\hline Dias & $\mathrm{Km}$ percorrido & Pontos & Localização & $\begin{array}{l}\text { Elementos } \\
\text { associados }\end{array}$ \\
\hline \multirow{3}{*}{$\begin{array}{c}1 \stackrel{0}{1} \\
\text { Dia }\end{array}$} & \multirow{3}{*}{36,2 km } & Maciço da Juréia & Iguape & $\begin{array}{l}\text { Histórico } \\
\text { Cultural }\end{array}$ \\
\hline & & $\begin{array}{c}\text { Cordões Litorâneos e Paleodunas da } \\
\text { praia da Jureia }\end{array}$ & Iguape & Biológico \\
\hline & & Morro do Espia & Iguape & $\begin{array}{l}\text { Histórico } \\
\text { Cultural }\end{array}$ \\
\hline \multirow{4}{*}{$\begin{array}{c}2^{\circ} \\
\text { dia }\end{array}$} & \multirow{4}{*}{$68,38 \mathrm{~km}$} & $\begin{array}{l}\text { Processos sedimentares da } \\
\text { desembocadura do rio Ribeira de } \\
\text { Iguape }\end{array}$ & $\begin{array}{l}\text { Iguape e Ilha } \\
\text { Comprida }\end{array}$ & $\begin{array}{l}\text { Histórico } \\
\text { Cultural }\end{array}$ \\
\hline & & $\begin{array}{l}\text { Campo de dunas } \\
\text { ativas do Araçá }\end{array}$ & Ilha Comprida & Biológico \\
\hline & & $\begin{array}{l}\text { Dunas, paleodunas e paleolagunas } \\
\text { da llha Comprida }\end{array}$ & Ilha Comprida & Biológico \\
\hline & & $\begin{array}{c}\text { Terraços holocênicos do Pontal da } \\
\text { Trincheira }\end{array}$ & Ilha Comprida & $\begin{array}{l}\text { Biológico } \\
\text { Geográfico }\end{array}$ \\
\hline \multirow{3}{*}{$\begin{array}{l}3^{\circ} \\
\text { dia }\end{array}$} & \multirow{3}{*}{$2,68 \mathrm{~km}$} & Serra do Itapitangui & Cananeia & Geográfico \\
\hline & & Morro São João & Cananeia & $\begin{array}{l}\text { Histórico } \\
\text { Biológico }\end{array}$ \\
\hline & & Terraço marinho do Mar Pequeno & Cananeia & Biológico \\
\hline $\begin{array}{l}4^{\circ} \\
\text { dia }\end{array}$ & $\begin{array}{l}43.9 \mathrm{~km} \\
81.9 \mathrm{~km}\end{array}$ & $\begin{array}{l}\text { Processos erosivos da Enseada da } \\
\text { Baleia }\end{array}$ & $\begin{array}{l}\text { Ilha do } \\
\text { Cardoso }\end{array}$ & $\begin{array}{l}\text { Histórico } \\
\text { Biológico } \\
\text { Cultural }\end{array}$ \\
\hline
\end{tabular}




\section{CONSIDERAÇÕES FINAIS E CONCLUSÕES}

\subsection{Sobre o inventário}

O método de seleção do inventário proposto por Brilha (2016) se mostrou eficiente, pois todas as unidades litoestratigráficas da área de estudo estão representadas nos sítios inventariados. Foram definidos 12 geossítios e 1 sítio da geodiversidade nos municípios de Iguape e llha Comprida, divididos em 6 Categorias Geológicas (CG).

Os locais de interesse geológico definidos são locais representativos da história geológica da região, que tem inicio no Paleoproterozoico. As CGs Terreno Curitiba, Magmatismo granítico sin-tectônico, Zonas de cisalhamento, Magmatismo alcalino do Cretáceo Tardio, demonstram terrenos afetados pelo Ciclo Brasiliano. Os processos sedimentares ocorridos no Cenozoico foram marcados por registros de regressão e progradação do nível relativo do mar e estão representados na CG Evolução Quaternária. Por fim, a CG Geomorfologia e evolução da paisagem, que representa a importância da geomorfologia na interpretação das recentes histórias geológicas do estado.

\subsection{Sobre a avaliação quantitativa}

Os resultados apresentaram a classificação da relevância cientifica dos geossítios, o potencial de uso educativo e turístico e o risco de degradação dos geossítios e sítio da geodiversidade.

$\mathrm{Na}$ relevância científica três geossítios foram classificados com relevância internacional e nove com relevância nacional. Estes resultados, aliados ao risco de degradação, foram utilizados para definir as prioridades de conservação. Dentre as causas de degradação antrópica, as mais preocupantes são a questão imobiliária e o turismo de aventura.

O método de quantificação se mostrou eficiente, porém em alguns parâmetros verificou-se a necessidade de modificações para adaptação à realidade brasileira. Segundo Romão e Garcia (2017), a plataforma GEOSSIT é o método de avaliação quantitativa mais utilizada nos inventários feitos no Brasil. Apesar de ser uma área 
restrita e com relativamente poucos locais de interesse geológico, a realização da quantificação se justifica, no caso, por esse trabalho integrar um inventário maior, que abrange todo o litoral do estado de São Paulo. Como os inventários nos outros municípios foram feitos com os mesmos métodos (Prochoroff, 2014, Reverte et al., 2016, Santos, 2014, Mucivuna et al, 2017; Arruda et al., 2017, Romão, 2018), a comparação entre as diferentes áreas é imediata, obedecendo a critérios em termos de representatividade dentro das categorias geológicas. Além disso, o uso de métodos comparáveis torna possível a inclusão destes locais em inventários estaduais e/ou nacionais.

O cálculo de prioridade de conservação mostrou que os geossítios que possuem alto risco de degradação são os locais onde há maior concentração turística, que estão localizados na praia, ambiente extremamente frágil e vulnerável. Uma das medidas que pode minimizar as ameaças aos geossítios mais frágeis é o controle de veículos na praia, principalmente sob as dunas, pois alguns passeios turísticos levam visitantes em "jeep" por cima das dunas, causando a retirada da vegetação e o retrabalhamento das areias, principalmente na parte nordeste da ilha, onde há maior densidade populacional.

\subsection{Sobre o enquadramento Legal}

Essa etapa foi necessária para enquadrar os sítios inventariados nas unidades de conservação da região. Apesar de existirem diversas UCs e legislações na região, algumas como o caso das APAs, não garantem uma plena preservação ambiental, são UCs de uso sustentável que sofrem dificuldades na fiscalização por serem grandes territórios e por possuírem áreas privadas.

Observa-se que no Brasil há pouquissimas leis que contemplem diretamente o meio abiótico, o que acaba negligenciando a conservação desses aspectos, assim como realizado em países como Portugal e Espanha (Dias et al. 2018), terminologias como os 5G's (Geodiversidade, Geoconservação, Patrimônio geológico, Geoturismo e Geoparques) são fundamentais para um melhor entendimento e conhecimento desse meio, podendo assim possibilitar ações de divulgação e valorização.

O SNUC estabelece que as UCs devem apresentar o Plano de Manejo cinco anos após a data de criação, embora este prazo nem sempre seja respeitado. 
Mesmo assim, a descrição do meio abiótico, nestes planos, é frequentemente feita de modo automático, com reaproveitamento de textos oriundos de relatórios antigos e desatualizados. Parte deste problema deve-se ao fato de não existirem dados atuais sobre a geodiversidade local. Portanto, a realização de inventários de locais de interesse geológico pode contribuir para que as UCs cumpram da melhor forma os objetivos propostos pela legislação e incluam, adequadamente, a gestão da geodiversidade em seus planos de manejo. Um exemplo disso é a APA Marinha Litoral Sul, cujo plano de manejo está em fase de elaboração. Os geossítios inventariados no estado de São Paulo (Garcia et al., 2018) estão em fase de inclusão, o que representa um avanço para a consolidação das estratégias de geoconservação.

\subsection{Sobre a integração dos dados e propostas de roteiros geoturísticos}

A integração dos dados apresentou sugestões de uso dos sítios inventariados com potenciais educativos e turísticos nas UCs em que se inserem. Essas ações buscam valorizar os aspectos mais representativos dos sítios no intuito de informar a população sobre os elementos da geodiversidade, sua importância para ciência e para a região, uma vez que todos os geossítios são importantes para o equilíbrio ambiental da área estudada.

A implementação dessas sugestões sobre geociências e junto aos elementos associados (histórico, cultural, biológico, etc.) em atividades de educação ambiental em zonas costeiras ajudam a compreender, de forma integrada, a complexa dinâmica dessas regiões tornando a atividade o mais interdisciplinar possível.

Os roteiros propostos são um exemplo de utilização do inventário como base para ações de conservação através do turismo e da educação e colaboram com a divulgação das geociências e, consequentemente, com a sua valorização. Ao mesmo tempo, a realização das rotas incentiva a prática esportiva e a utilização sustentável da natureza como recreação.

Há planos para que os sítios geológicos e os outros elementos incluídos nos roteiros sejam acrescentados a uma plataforma de dados online já existente, desenvolvida pelo Núcleo de Apoio à Pesquisa em Patrimônio Geológico e Geoturismo (GeoHereditas). A consulta de mapas e de informações sobre os locais, também serão disponibilizados. Atividades com a utilização dos sítios apresentados 
na plataforma poderão complementar o conhecimento sobre a natureza e incentivar o aprendizado de maneira lúdica, estimulante e divertida. Dessa forma, essa prática pode favorecer a transmissão de conceitos, a divulgação de geociências e a educação ambiental.

Assim, essas propostas têm o objetivo principal de trazer o público para a realidade local, disponibilizando informações que foram desenvolvidas em pesquisas científicas para a população. Por isso, constituem-se em ótimos mecanismos de diálogo entre a universidade e a população. Espera-se que essas propostas sejam apresentadas para UCs e que sejam implementadas aos projetos educativos e turísticos promovidos pelas unidades.

\subsection{Outras considerações}

Os dados obtidos neste trabalho podem fornecer subsídios para várias atividades. Um exemplo são os cursos de capacitação de monitores ambientais. Trabalhos como o de Garcia et al. (2016) e Boggiani (2018) apresentam a necessidade de um condutor local que possua um mínimo de conhecimento sobre a dinâmica do Planeta Terra, integrando, dessa forma, outros elementos associados, tais como biologia, história e cultura.

Inventários no âmbito educacional, através da Aprendizagem Social (Bacci et al, 2013), também podem ser fomentados por meio dos dados ora obtidos. Esses inventários utilizam as metodologias participativas como uma eficiente ferramenta para a prática de educação para a geoconservação e a sustentabilidade, em que se tem o envolvimento de diversos atores sociais em prol de melhorias no ambiente em que vivem. Trabalhos como o de Soares (2016) em escolas da rede pública e Mazzucato (2017) em unidades de conservação demonstram que as efetivas participações da população nas estratégias de geoconservação podem promover uma transformação coletiva social.

\subsection{Conclusões}

As regiões costeiras são ambientes dinâmicos, atingidos por processos continentais e oceânicos. São paisagens que podem sofrer rápidas mudanças. As 
ocupações urbanas nestas áreas geram um maior impacto dos processos costeiros e a falta de proteção de alguns locais pode causar sérios danos aos ecossistemas presentes. Isso, consequentemente, pode afetar a população direta e indiretamente, pois são locais que fornecem bens e serviços necessários para a vida humana.

Este inventário demonstrou o quanto o meio físico reage diante das mudanças na paisagem, tanto por atividades antrópicas quanto naturais, justificando assim a necessidade de estratégias que minimizem os impactos ambientais na sua vertente geológica, mas que, ao mesmo tempo ,não limitem o uso pela a população.

Os dados desse inventário podem futuramente ser alterados, pois novas pesquisas irão surgir e ser complementados as estratégias de geoconservação. É necessário, a partir de agora, que os resultados dessa pesquisa sirvam de base para a realização das etapas de proteção, valorização e divulgação e monitoramento, para que os locais de interesse geológico sejam efetivamente conservados da melhor forma a fim de garantir esse conhecimento para as gerações futuras.

Com essas propostas pretende-se mudar o olhar e o comportamento das pessoas sobre o meio, de modo que essas respeitem o uso que cada local inventariado suporta. Essas ações propiciam, além do diálogo entre universidade/população por meio da participação, podem trazer um sentimento de pertencimento e co-responsabilização sobre o meio ambiente. 


\section{REFERÊNCIAS}

Ab'Saber, A.N., 2007, Brasil: Paisagens de exceção: o litoral e o Pantanal Matogossense: patrimônios básicos: Ateliê Editorial, Cotia - SP.

Almeida, F.F.M., Hasui Y., Brito-Neves B.B de, Fuck R. A. 1977. As províncias estruturais do Brasil. In: SBG, Simp Geol. Nordeste, 8, Bol. Esp., 12p.

Almeida, F.F.M.; Carneiro, C.D.R., 1998, Origem e Evolução da Serra do Mar: Revista Brasileira de Geociências,v.28, n.2, p. 135-150.

Arruda K.E.C., Garcia M.G.M., Del Lama E.A., 2017, Inventário e quantificação do patrimônio geológico do município de Caraguatatuba, São Paulo: Revista Geociências UNESP, v.36, n.3, p. 447-462.

Bacci, D.C., Jacobi, P.R., Santos, V.M.N., 2013, Aprendizagem Social nas Práticas Colaborativas: exemplos de ferramentas participativas envolvendo diferentes atores sociais: Alexandria, v.6, n.3, p. 227-243.

Bacci, D.L.C., Kuntschik, G., 2013, Recursos naturais, in Jacob, P.R., org., Aprendizagem Social e Unidades de Conservação: São Paulo, IEE/PROCAM, p. 21-27.

Becegato, J.L., Suguio, K., 2007, Impacto Ambiental Antrópico na APA da Ilha Comprida (SP): Da Pré-História à atualidade: Revista UNG - Geociências, v.6, n.1, p.107-117.

Bentz, D., 2004, Os cordões litorâneos da Planície de Uma-Jureia, municípios de Peruíbe e Iguape [Dissertação de Mestrado]: São Paulo, Universidade de São Paulo, Instituto de Geociências, 134 p.

Boggiani, P. C., 2018. A importância dos condutores de visitantes na divulgação das Geociências em unidades de conservação. REVISTA TERRAE DIDATICA, v. 14, p. 463-466.

Boggiani, P.C., 2010, A aplicação do conceito de Geoparque da UNESCO no Brasil e relação com o SNUC - Sistema Nacional de Unidades de Conservação: Revista eletrônica Patrimônio Geológico e Cultura, v.1, n.1.

Brasil. 2000. Lei oㅜ 9.985 de 18 de julho de 2000 - Regulamenta o artigo 225, § $1^{\circ}$, incisos I, II, III e VII da Constituição Federal, institui o Sistema Nacional de Unidades deConservação da Natureza e dá outras providências. Disponível em: http://www.planalto.gov.br/ccivil_03/leis/L9985.htm. Acessado em 25 janeiro 2019 
Brilha, J.B.R., 2005, Patrimônio Geológico e Geoconservação: a conservação da natureza na sua vertente geológica. Palimage Editora, Braga, 190 p.

Brilha, J.B.R., 2016, Inventory and Quantitative Assessment of Geosites and Geodiversity Sites: a Review: Geoheritage, v. 18, p. 119-134.

Brilha, J.B.R., 2018, Geoheritage: inventories and evaluation, in Reynard,E., Brilha, J.,eds., Geoheritage Assessment, Protection, and Management: Elsevier, Amsterdam, p. 69-86.

Carvalho, M.C.P., 1999, Histórias da ilha: temporalidades e apropriação do espaço na Ilha Comprida [Dissertação de Mestrado]: Campinas, Universidade Estadual de Campinas, Instituto de Filosofia e Ciências Humanas, 201 p.

CONDEPHAAT, Resolução de tombamento 11 de 25/07/79 in: Livro do Tombo Arqueológico, Etnográfico e Paisagistico: inscrição nำ, p.303, 18/08/1986. Disponivel em:

Cury, L. F., 2009,Geologia do Terreno Paranaguá [Tese de Doutorado]:São Paulo, Universidade de São Paulo, Instituto de Geociências, 202 p.

Diegues, A.C., 1997, As ilhas e arquipélagos tropicais brasileiros: Práticas sociais e simbólicas. In: Ilhas e Sociedades Insulares. Diegues, A. C., (org): São Paulo, NUPAUB - $\quad$ USP. $\quad$ p.248. Disponivel em: http://nupaub.fflch.usp.br/sites/nupaub.fflch.usp.br/files/color/lhas_Sociedades_In sulares.pdf. (Acesso: 20 de Janeiro de 2019).

Fuertes-Gutiérrez, I., Fernández-Martínez, E., 2010, Geosites inventory in the Leon Province (Northwestern Spain): A tool to introduce geoheritage into regional environmental management: Geoheritage, v.2, p.57-75.

Fundação Florestal, 2018, De olho no futuro, natureza se transforma em sala de aula: Disponivel em: http://fflorestal.sp.gov.br/de-olho-no-futuro-natureza-se-transformaem-sala-de-aula/ Acesso 25 de Janeiro de 2019.

Garcia M.G.M., Del Lama, E.A., Martins, L., Mazoca, C.E.M., Bourotte C.L.M., 2018, Inventory and assessment of geosites to stimulate regional sustainable management: the northern coast of the state of São Paulo, Brazil:Anais da Academia Brasileira de Ciências (no prelo).

Garcia, M.G.M., 2012, Gondwana Geodiversity and Geological Heritage: examples from the north coast of São Paulo State, Brazil:Anuário do Instituto de Geociências, v.35, p.101-111. 
Garcia, M.G.M., et al. 2017. The inventory of geological heritage of the State of São Paulo, Brazil: methodological basis, results and perspectives: Geoheritage, v.10, n.2, p. 239-258.

Garcia, M.G.M., Martins, L., Del Lama, E.A., Bourotte, C., 2014, O Inventário do patrimônio geológico da região costeira do estado de São Paulo: base metodológica, adaptações e considerações. In: 47ํㅡㄹ Congresso Brasileiro de Geologia. Salvador, Anais, p. 49.

Garcia, M.G.M., Reverte, F. C., Mucivuna, V.C, Arruda, K.E.C., Santos, P.L.A., Prochoroff, R., Romão, R.M.M. 2016. A geodiversidade como parte do meio natural em áreas protegidas: experiência com cursos para monitores ambientais no litoral norte de São Paulo. In: 48ํㅡㄹ Congresso Brasileiro de Geologia. Porto Alegre.

García-Cortéz A., Carcavilla Urquí L., 2009,Documento metodológico para la elaboración del inventario español de lugares de interés geológico (IELIG): Instituto Geológico y Minero de España, Madrid, v.12, p.61.

García-Ortiz, E., Fuertes-Gutiérrez, I., Fernández-Martínez, E., 2014,Concepts and terminology for the risk of degradation of geological heritage sites: fragility and natural vulnerability, a case study, in Proceedings of Geologists' Association, v.125, p. 463-479.https://doi.org/10.1016/j.pgeola.2014.06.003

GEOBRÁS, 1966, Complexo Valo Grande, Mar Pequeno, Rio Ribeira de Iguape. Relatório para o serviço do Vale do Ribeira - São Paulo: DAEE, v. 1, p.448.

Giannini, P.C.F., Guedes, C.C.F., Angulo, R.J., Nascimento Jr., D.R., Tanaka, A.P.B., Fornari, M., Souza, M.C. Bentz, D., 2018, Contexto geológico e evolução sedimentar quaternária das barreiras costeiras e sistema estuarino-lagunar associado de Cananeia - Iguape - Ilha Comprida, in Machado, R., Góes, A.M., Moraes, M.C., Bartorelli, A., org., Setembrino Petri: do Proterozoico ao Holoceno. São Paulo, SBG, no prelo. 50 p.

Giannini, P.C.F., Guedes, C.C.F., Nascimento Jr., D.R., Tanaka, A.P.B., Angulo, J.R.,Assine, M.L., Souza, M.C., 2008. Sedimentology and morphologic evolution ofthe Ilha Comprida Barrier System, southern São Paulo coast, in Dillenburg, S.R., Hesp, P. eds., Geology of the Brazilian Coastal Barriers: Lecture Notes in Earth Sciences, Springer-Verlag, Heidelberg. DOI: 10.1007/978-3-540-44771-9_6

Gray, M., 2013, Valuing and conserving abiotic nature: John Wiley \& Sons, Londres, 508 p. 
Gray, M., 2018, Geodiversity: the backbone of geoheritage and geoconservation, in E. Reynard, J. Brilha, eds., Geoheritage: Assessment, Protection and Management. Elsevier, p. 13-25.

Guedes C.C.F., Giannini P.C.F., Sawakuchi A.O., DeWitt R., D.R. Nascimento Jr., Aguiar, V.A.P. a, Rossi, M.G., 2011. Determination of controls on Holocene barrier progradation through application of OSL dating: The llha Comprida Barrier example, Southeastern Brazil: Marine Geology,v.285, p.1-16.

Guedes, C.C.F., 2003, Os Cordões Litorâneos e as Dunas Eólicas da Ilha Comprida, Estado de São Paulo [Monografia de Trabalho de Formatura]: São Paulo, Universidade de São Paulo, Instituto de Geociências, 53 p.

Guedes, C.C.F., 2009, Evolução sedimentar quaternária da llha Comprida, estado de São Paulo [Dissertação de Mestrado]: São Paulo, Universidade de São Paulo, Instituto de Geociências, 147p.

Heilbron, M., Pedrosa Soares, A.C., Campos Neto, M. C., Silva, L. C., Trow, R. A. J., Janasi, V. A.,2004,Província Mantiqueira,in Geologia do Continente SulAmericano, São Paulo: Beca, Cap. XIII, 205 p.

Hose, T. A., 2000, European "Geotourism" - geological interpretation and geoconservation promotion for tourists, in Barettino, D., Wimbledon, W. A. P., Gallego, E., eds.,Geological Heritage: Its Conservation and Management:Madrid, Spain, p. 127-146.

http://condephaat.sp.gov.br/benstombados/copia-copia-copia-modelo-nome-do-bem-tombadocopia-copia-copia/\#. Acesso em: 23/01/2019.

IBGE - Instituto Brasileiro de Geografia e Estatística. Cidades@. Disponível em: http://www.cidades.ibge.gov.br/xtras/home.php Acesso em: 10 janeiro 2019 ICMBIO - Intituto de Conservação Chico Mendes. Grupos Disponivel em: http://www.icmbio.gov.br/portal/unidadesdeconservacao/grupos Acesso 20 de janeiro de 2019

Italiane, D.M., Mahiques, M.M., 2014, O Registro da atividade antropogênica na região do Valo Grande, Estado de São Paulo, Brasil,in Quaternary and Environmental Geosciences. v.5, n.2., DOI: http://dx.doi.org/10.5380/abequa.v5i2.34522.

Jacobi, P.R., 2005, Educação Ambiental: o desafio da construção do pensamento crítico, complexo e reflexivo: Educação e Pesquisa, São Paulo, v.31, n.2, p.233250. 
Câmara, J.C., 2009. O Parque Itinguçu, Município de Iguape-SP: a problemática da relação Estado e população local. [Dissertação de Mestrado]: Piracicaba, Universidade de São Paulo, ESALQ, p.91

Magalhães, N.W., 2003, Descubra o Lagamar. 2 ed. São Paulo: Terragraph Mahiques, M.M., Burone, L., Figueira, R.C.L., Lavenére-Wanderley, A.A.O., Capellari,B., Rogacheski, C.E., Barroso, C.P., Santos, L.A.S., Cordero, L.M., Cussioli, M.C., 2009,Anthropogenic influences in a lagoonal environment: a multiproxy approach at the Valo Grande mouth, Cananeias-Iguape system (SE Brazil): Brazilian Journal of Oceanography, v. 57, n. 4, p. 325-337.

Martin, L., Suguio, K., 1978, Ilha Comprida: um exemplo de ilha barreira ligada às flutuações do nível marinho durante o Quaternário: Congresso Brasileiro de Geologia, Recife, PE, Anais, p. 905-912.

Mazzucato, E., 2017, Estratégias de Geoconservação no Parque Estadual da Serra do Mar - Núcleo Pinciguaba e Caraguatatuba (SP). [Dissertação de Mestrado]: São Paulo, Univeridade de São Paulo, Intituto de Geociências p.320.

Melo, M.S., 1990, A Formação Pariqüera-Açu e Depósitos Relacionados: Sedimentação, Tectônica e Geomorfogênese [Dissertação de Mestrado]: São Paulo, Universidade de São Paulo, Instituto de Geociências, 211p.

MMA - Ministério do Meio Ambiente/ Instituto Chico Mendes, 2016. Plano de Manejo da APA Caneia, Iguape e Peruibe. Disponivel em: http://www.icmbio.gov.br/portal/images/stories/DCOM plano de manejo Apa Cananeia Iguape_Peruibe_03032016.pdf acessado em 20 de novembro de 2018.

MMA. Ministério do Meio Ambiente, 2010, Panorama da conservação dos ecossitemas costeiros e marinhos do Brasil. Brasilia: MMA, 152 p. Disponivel em:http://www.mma.gov.br/estruturas/205/_publicacao/205_publicacao030220111 00749.pdf. Acesso em: 20 de janeiro de 2019

Moreira, J.C., 2010, Geoturismo: uma abordagem hitórico-conceitual. Turismo e Paisagens Cársticas, v.3, n.1, p.5-10.

Mucivuna, V.C., Del Lama E.A., Garcia, M.G.M., 2016. Aspectos geológicos, históricos e estado de conservação das fortificações da Baixada Santista, litoral paulista: Revista do Instituto Geológico, v.37, n.1,p. 29-48.

Mucivuna, V.C., Garcia, M.G.M., Del Lama, E.A., 2017, Inventário e avaliação quantitativa do patrimônio geológico do município de Bertioga, SP: Revista Pesquisas em Geociências, UFRGS,v.44, p. 293-321. 
Nascimento Junior, D.R., 2006, Morfologia e sedimentologia ao longo do sistema praia-duna frontal de Ilha Comprida, SP [Dissertação de Mestrado]:São Paulo, Universidade de São Paulo, Instituto de Geociências, 96 p.

Nascimento, M.A,L., Ruckys, U.A., Mantesso-Neto, V., 2007. Geoturismo: um novo segmento do turismo no Brasil. Global Tourism, v.3, n.2

Nascimento, F.B., Scifoni, S., 2015, O Tombamento de Iguape como Patrimônio Nacional: Novas Práticas e Políticas de Preservação: PARC, Campinas, v. 6, n. 1, p. 1-13.

Passareli, C.R., 2001,Caracterização estrutural e geocronológica dos domínios tectônicos da porção sul-oriental do Estado de São Paulo [Tese de Doutorado]: São Paulo, Universidade de São Paulo,Instituto de Geociências, 254 p.

Pereira Junior, C. A., 2005, IGUAPE: Conto, canto e encanto com a minha história. São Paulo: Noovha America, 128 p. ISBN 85-7673-044-8

Pereira, R.F., Brilha, J.B.R., Martinez, J.E., 2008, Proposta de enquadramento dageoconservação na legislação ambiental brasileira: Memórias e Notícias, n.3, p. 491-494.

Perrotta, M.M. et al. 2005. Mapa geológico do Estado de São Paulo, escala 1:750.000. São Paulo: CPRM, (Programa Levantamentos Geológicos Básicos do Brasil).

Picanço, J.L., 1994, Aplicação das sistemáticas Sm/Nd e Rb/Sr no Maciço Itatins (SP) [Tese de Mestrado]: São Paulo, Universidade de São Paulo, Instituto de Geociências. 140 p.

Prefeitura da Estância Balneária da Ilha Comprida - PEBIC. Contém informações sobre 0 município de llha Comprida. Disponível em: < http://www.ilhacomprida.sp.gov.br/home/>. Acesso em: 20 janeirode 2019.

Prochoroff R. 2014. O patrimônio geológico de llhabela-SP: estratégias de geoconservação. Dissertação de Mestrado, IGc/USP, 176p.

Reverte, F.C., Garcia, M.G.M., 2016, Avaliação quantitativa do patrimônio geológico:aplicação aos geossítios de São Sebastião, litoral norte do estado de São Paulo: Anuáriodo Instituto de Geociências - UFRJ, v.39, n.2, p. 43-56.

Rocha, A.J.D., Lima, E., Schobbenhaus, C., 2016,Aplicativo Geossit: nova versão: 48ํㅡㄹ Congresso Brasileiro de Geologia. Anais. São Paulo - SP. SBG. Disponível em: http://cbg2017anais.siteoficial.ws/anais48cbgcompleto.pdf 
Romão R.M.M., 2017, Métodos de inventário e avaliação quantitativa de locais de interesse geológico no Brasil: visão geral e aplicação ao município de Cananeia, litoral sul do estado de São Paulo. Dissertação de Mestrado, IGc/USP, 82p.

Romão R.M.M., Garcia, M.G.M., 2017, Iniciativas de inventário e quantificação do patrimônio geológico no Brasil: panorama atual: Anuário do Instituto de Geociências - UFRJ,v.40, n.2, p.250-265.

Romão, R.M.M., Somekawa, S., Garcia, M.G.M., Mazoca, C.E.M., 2018, A divulgação de geociências através da bicicleta: proposta de rota na região do lagamar paulista. In: 49ํㅡㄹ Congresso Brasileiro de Geologia, Rio de Janeiro

Santos PLA. 2014. Patrimônio geológico em áreas de proteção ambiental: Ubatuba SP. [Dissertação de Mestrado]: São Paulo, Universidade de São Paulo, Instituto de Geociências, 208p.

Scatamacchia, M.C.M., 2004, Os primeiros habitantes do Baixo Vale do Ribeira. in:

Diegues, A.C.S., Enciclopédia Caiçara: O olhar do pesquisador. São Paulo: HUCITEC- NUPAUB, v1, p.382

SMA, 2014 - Secretaria do Estado do Meio Ambiente. Cadernos de Educação Ambiental: Unidades de Conservação da Natureza. São Paulo: Secretaria do Meio Ambiente (SMA), p. 104.

Soares, D.B., 2016, Formação continuada de professores em Geociências com metodologias participativas: contribuições à Educação para Geoconservação [Dissertação de Mestrado], Campinas,Universidade Estadual de Campinas, Instituto de Geociências, 186 p.

Somekawa, S., Garcia, M.G.M., 2017. Patrimônio Geológico em áreas protegidas: geossítios da Estação Ecológica Jureia-Itatins em Iguape, litoral sul do Estado de São Paulo. In: Anais IV Simpósio Brasileiro de Patrimônio Geológico, Ponta Grossa PR, p.658-662

Souza, C.R.G, 2010, Impactos das Mudanças Climáticas no litoral do Estado de São Paulo in: VI Seminário Latino Americano de Geografia Física, Universidade de Coimbra. p. 17

Souza, C.R.G., Souza, A.P., 2002,Geologia e Geomorfologia da Área da Estação Ecológica Juréia-Itatins, in Marques,O.A.V., Duleba, W., eds., Estação Ecológica Juréia-Itatins. Ambiente Físico, Flora e Fauna, Holos Editora, p. 16-33. 
Souza, T.A., 2014, Dinâmica geomorfológica e alterações antrópicas da Ilha Comprida (SP) [Tese de Doutorado]: Campinas, Universidade Estadual de Campinas, Instituto de Geociências, 194 p.

Spinelli, F.P., 2007. As rochas alcalinas de Cananeia, litoral sul do Estado de São Paulo: estudos mineralógicos, geoquímicos e isotópicos. [Tese de Doutorado]: São Paulo, Universidade de São Paulo, Instituto de Geociências. p.138

Suguio, K., Martin, L., 1978. Formações quaternárias marinhas do litoral paulista e sul fluminense in Coastal Evolution in the Quaternary : International Symposium, Sao Paulo, p.57

Suguio, K., Martin, L., 1994, Geologia do Quaternário, in Falconi, F.F.,Nigro Jr, A., eds., Solos do litoral de São Paulo: Mesa Redonda, ABMS/ASSECOB, p. 69-97.

Suguio, K., Tatumi, S.H., Kowata, E.A., 1999. As cristas de dunas inativas e os seus possíveis significados na evolução holocênica da Ilha Comprida, Sul do litoral paulista. Abstracts of the $7^{\circ}$ Congresso da ABEQUA, Porto Seguro

Suguio, K.; Petri, S., 1973, Stratigraphy of the Iguape-Cananéia lagoonal region sedimentary deposits, São Paulo state, Brazil.Part I-Field observations and grain size analysis:Boletim IG, Instituto de Geociências, USP, v. 4, p. 1-20.

Tessler, M.G.,Suguio, K.; Mahiques, M.M., Furtado, V.V., 1990, Evolução temporal e espacial da desembocadura lagunar deCananéia (SP).Bol. Inst. Oceanogr., v.38, n.1, p.23-29. 